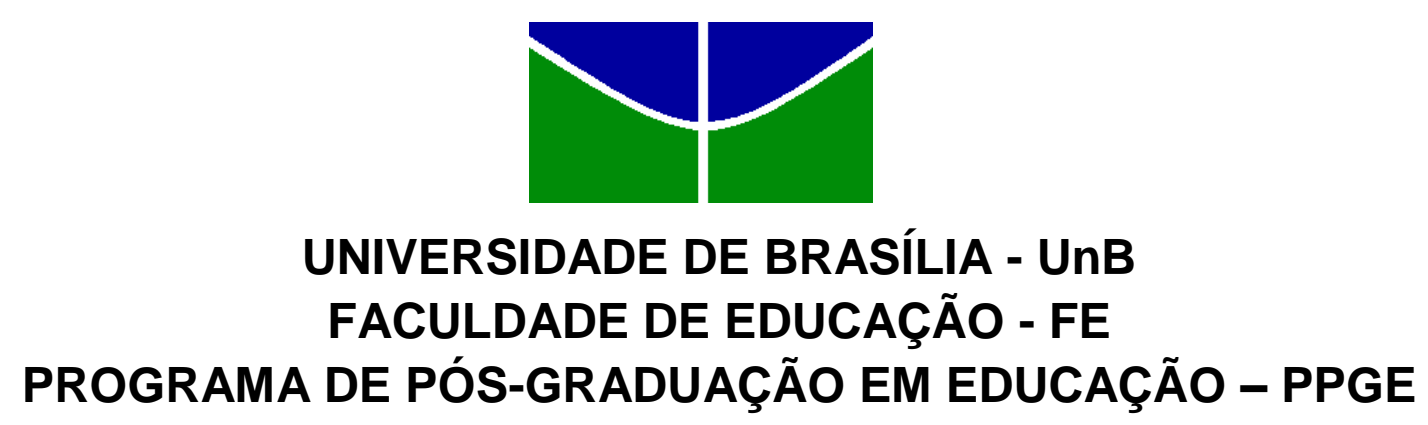

Tese

Subjetividade, Educação Física e Saúde Mental: desdobramentos educativos em face à emergência dos sujeitos nos Centros de Atenção Psicossocial - CAPS

Jonatas Maia da Costa

Brasília

2016 
Ficha catalográfica elaborada automaticamente, com os dados fornecidos pelo(a) autor(a)

Costa, Jonatas Maia da

Subjetividade, Educação Física e Saúde Mental: desdobramentos educativos em face à emergência dos sujeitos nos Centros de Atenção Psicossocial - CAPS / Jonatas Maia da Costa; orientador Fernando Luis González Rey. -- Brasília, 2016.

$163 \mathrm{p}$.

Tese (Doutorado - Doutorado em Educação) -Universidade de Brasília, 2016.

1. Subjetividade. 2. Educação Física. 3. Saúde Mental. 4. Educação. 5. Saúde Pública. I. González Rey, Fernando Luis, orient. II. Título. 


\section{Subjetividade, Educação Física e Saúde Mental: desdobramentos educativos em face à emergência dos sujeitos nos Centros de Atenção Psicossocial - CAPS}

Jonatas Maia da Costa

Tese apresentada à Faculdade de Educação da Universidade de Brasília, como parte da defesa de doutorado e requisito obrigatório à obtenção do título de Doutor em Educação.

Orientador: Prof. Dr. Fernando González Rey 


\section{Subjetividade, Educação Física e Saúde Mental: desdobramentos educativos em face à emergência dos sujeitos nos Centros de Atenção Psicossocial - CAPS}

Aprovada em: I I

BANCA EXAMINADORA

Prof. Dr. Fernando Luís González Rey (Presidente)

Faculdade de Educação - UnB

Profa. Dra. Cristina Massot Madeira Coelho (membro interno)

Faculdade de Educação - UnB

Profa. Dra. Júlia Aparecida Devide Nogueira (membro externo)

Faculdade de Educação Física - UnB

Profa. Dra. Valéria Deusdará Mori (membro externo)

Faculdade de Ciências da Saúde e Educação - UniCEUB

Prof. Dr. Alexandre Luiz Gonçalves de Rezende (membro externo)

Faculdade de Educação Física - UnB

Profa. Dra. Maria Carmen Villela Tacca (suplente)

Faculdade de Educação - UnB 


\section{AGRADECIMENTOS}

Concluir um trabalho como este não é simples. Imaginar que a sua elaboração em muitos momentos foi realizada em clima de solidão, embora real, no fundo, me parece uma grande contradição. Creio que é inevitável viver tais momentos "sozinhos" a fim de dar conta da diligência de se escrever uma tese. Entretanto, compreender-se sozinho é de fato um engano. Sobre isso, dou razão ao Gonzaguinha, o poeta que cantava o seguinte:

Toda pessoa

É sempre as marcas

Das lições diárias de outras tantas pessoas

E é tão bonito quando a gente entende

Que a gente é tanta gente

Onde quer que a gente vá

E é tão bonito quando a gente sente

Que nunca está sozinho

Por mais que pense estar (...)

Logo, jamais estive sozinho...

Assim, vale registrar meus especiais agradecimentos aos colegas do grupo de pesquisa Subjetividade na Educação e na Saúde: Daniel Goulart, José Fernando Patiño, Eduardo Moncayo, Ana Orofino, Elias Caires, Marília Bezerra, Cristina Coelho, Ana Luíza Sá, Virgínia Silva, Giselle Silva, Luiz Martins, Laura Vidaurreta e José Odair Nunes (Zeca).

Aos amigos da Faculdade de Educação Física e Dança da Universidade Federal de Goiás: Marcel Sousa, Roberto Furtado, Mário Hebling, Ana Márcia Silva, Priscila Antunes, Jéssica Félix, Flórence Faganello, Anegleyce Teodoro, Ricardo Lira, Tadeu Baptista, Ana de Pellegrin, Ana Paula Salles, Hugo Silva, Nilva Pessoa, Jaciara Leite, Humberto de Deus, Nivaldo David, José Luiz Falcão, Caio Antunes, Ari Lazarotti, Sissília Vilarinho, Wilson Lino, Eduardo (atualmente na UFU), Vanessa Dalla Dea, Vicente Dalla Dea, Juracy da Silva, Sérgio Moura e 
José Pedro Alvarenga (Zé Pedro). Devo a eles uma virada política e de formação humana em Educação Física importante em meu pensamento.

Ao amigo Raimundo Nonato Brito Brandão, garçom do Sebinho. Ele foi testemunha de meu esforço para completar este trabalho e me ajudou bastante nos momentos de angústia intelectual, quando a tese parecia não "querer se materializar". Com Raimundo fiz minha terapia...

E finalmente, um agradecimento especial ao meu orientador, o Prof. Dr. Fernando González Rey. Conviver com a sua genialidade foi um grande privilégio. Lembranças e aprendizagens que levarei para sempre comigo. 


\section{DEDICATÓRIA}

Dedico este trabalho aos meus filhos, Lucas e João Vitor.

A minha esposa, Renata Lino.

Aos meus pais, Seu Costa e Dona Vivian.

E aos meus irmãos, Jefferson e Veruska. 


\section{SUMÁRIO}

$\begin{array}{ll}\text { Resumo } & 09\end{array}$

$\begin{array}{ll}\text { Abstract } & 10\end{array}$

$\begin{array}{ll}\text { I. INTRODUÇÃO } & 12\end{array}$

II. FUNDAMENTAÇÃO TEÓRICA 23

SUBJETIVIDADE, EDUCAÇÃO E SAÚDE 24

A Teoria da Subjetividade numa perspectiva cultural-histórica: primeiras aproximações $\quad 24$

A inserção da Teoria da Subjetividade na Educação e na Saúde 33

EDUCAÇÃO FÍSICA, SUBJETIVIDADE E SAÚDE PÚBLICA 41

Breves apontamentos históricos da relação entre

a Educação Física e Saúde $\quad 41$

O debate crítico da Educação Física na Saúde 44

Reflexões em perspectiva para projetar a Educação Física

na Teoria da Subjetividade 53

SAÚDE MENTAL, EDUCAÇÃO E EDUCAÇÃO FÍSICA 59

Epistemologia e intervenção profissional na saúde mental:

aspectos históricos da reforma psiquiátrica brasileira

e o campo da educação como perspectiva 59

O não-lugar da educação física na saúde mental: uma incipiente incursão científica

$\begin{array}{ll}\text { III. METODOLOGIA } & 74\end{array}$

Fundamentos Teóricos da Epistemologia Qualitativa:

a prática da construção de uma outra racionalidade 
O processo de construção do cenário de pesquisa

O locus da investigação: o Centro de Atenção Psicossocial (CAPS) $\quad 89$

Instrumentos de pesquisa $\quad 92$

Investigando singularidades: os sujeitos colaboradores da pesquisa $\quad 98$

Apontamentos metodológicos sobre a organização da informação 100

IV. CONSTRUÇÃO DA INFORMAÇÃO 102

Considerações iniciais sobre a construção da informação 103

CONFIGURAÇÕES SUBJETIVAS DA ATUAÇÃO

DA EDUCAÇÃO FÍSICA EM CAPS: DILEMAS E DESAFIOS

105

A emergência da educação física como área de conhecimento e intervenção em saúde mental: contradições e possibilidades

A educação física em meio a uma equipe multiprofissional em CAPS:

competência e legitimidade em saúde mental

À guisa de conclusão

126

CONFIGURAÇÕES SUBJETIVAS DA PRÁTICA

DA EDUCAÇÃO FÍSICA EM CAPS: PRODUÇÃO

DE SENTIDO EM QUEM VIVE ÀS PRÁTICAS CORPORAIS

Breves reflexões sobre a subjetividade social do CAPS:

conjuntura política da saúde mental do DF

e a emergência das práticas corporais como resposta terapêutica

Práticas corporais como produção de sentido subjetivo:

vivências na oficina de futebol

$\begin{array}{ll}\text { À guisa de conclusão } & 145\end{array}$

V. CONSIDERAÇÕES FINAIS 148

VI. REFERÊNCIAS 156 


\section{RESUMO}

Este estudo constitui-se numa pesquisa vinculada ao Programa de Pósgraduação Stricto-Sensu da Faculdade de Educação da Universidade de Brasília PPGE/UnB, na linha de pesquisa "Escola, aprendizagem, ação pedagógica e subjetividade na educação", circunscrito ao eixo de interesse "O sujeito que aprende, processos de aprendizagem e saúde". Produz uma investigação no campo da Saúde Pública, especificamente tomando como lócus de pesquisa os Centros de Atenção Psicossocial (CAPS), na tentativa de entender os sentidos subjetivos da atuação do professor de Educação Física que integra uma equipe multiprofissional no interior de um projeto terapêutico e que objetiva cuidar de sujeitos que apresentam transtornos psíquicos. Opta pela Teoria da Subjetividade de González Rey como referencial teórico da pesquisa. Metodologicamente a pesquisa se estrutura a partir da Epistemologia Qualitativa (GONZÁLEZ REY, 2005), no qual se enaltece a elaboração teórica a partir de uma abordagem construtivo-interpretativa. Destacam-se aspectos que aludem para a necessidade da atuação de professores de educação física deslocar a centralidade do processo para os sujeitos que vivem as práticas corporais em meio a um contexto relacionado à saúde mental, de forma a contemplar a possibilidade de emergência da subjetividade dos sujeitos-usuários do CAPS. Defende-se que a Teoria da Subjetividade numa perspectiva cultural-história promove uma abertura alternativa para o debate epistemológico e a produção de conhecimento científico em educação física, mormente em sua interface com as ciências humanas e sociais.

Palavras-chave: Educação Física. Subjetividade. Saúde Mental. Saúde Pública. 


\begin{abstract}
This study constitutes a linked research to Stricto-Sensu Postgraduate Program of the Faculty of Education, University of Brasilia - PPGE / UnB in the line of research "School, learning, pedagogical action and subjectivity in education", confined to the axis of interest "The guy who learns, learning processes and health." It produces research in the field of public health, specifically taking as research locus Psychosocial Care Centers (CAPS) in an attempt to understand the subjective meanings of the performance of a physical education teacher who is part of a multidisciplinary team within a therapeutic project and which aims to care for individuals who have mental disorders. Opts for Subjectivity Theory of González Rey as theoretical research framework. Methodologically the research is structured from the Qualitative Epistemology (GONZÁLEZ REY, 2005), in which he extols the theoretical elaboration from a constructive-interpretative approach. A key aspect that allude to the need for performance of physical education teachers displace the centrality of the process for the subjects living bodily practices in a context related to mental health in order to contemplate the possibility of the emergence of subjectivity of subject-users CAPS. It is argued that the theory of subjectivity in a cultural-historical perspective promotes an alternative opening to the epistemological debate and the production of scientific knowledge in physical education, especially in its interface with the human and social sciences.
\end{abstract}

Keywords: Physical Education. Subjectivity. Mental health. Public health. 
A definição do tema da subjetividade tem a pretensão de gerar visibilidade sobre processos da psique humana e da sociedade que têm sido subestimados até o presente momento, tanto na construção teórica quanto no desenvolvimento de práticas e políticas sociais.

Fernando González Rey 


\section{I - INTRODUÇÃO}

A maneira como este estudo está estruturado fortalece o desejo de contrapor uma hegemonia histórica da produção de conhecimento em educação física no Brasil, bem como tensionar o campo de atuação deste profissional ${ }^{1}$ que, embora possua uma formação generalista, dispõe de uma intervenção fundada num aporte pedagógico que objetiva essencialmente a formação humana. Neste caso, trata-se de uma investigação que visou atravessar o campo da saúde, tendo na educação física o seu maior protagonista e na saúde mental o cenário desse profissional que tem sido inserido nos espaços da saúde pública por meio dos Centros de Atenção Psicossocial (CAPS).

A interface da educação física com o campo da saúde é histórica e guarda certos tensionamentos. A gênese da educação física no Brasil ocorreu no final do século XIX e início do século $X X$ e se constituiu a partir do contexto da educação formal. As características assumidas por ela permearam uma sólida construção epistemológica edificada no positivismo e numa concepção biologicista de corpo, fato que marcou a formação profissional centrada no estudo de disciplinas biomédicas, como a fisiologia, a anatomia e a cineantropometria (CARVALHO, 2004). Somente a partir da década de 1980, com o advento das pedagogias críticas somadas ao processo de redemocratização brasileira e consequente avanço de um pensamento progressista político e pedagógico, a educação física pôde reformular no interior do seu estatuto científico a perspectiva de formação, centrada, então, na intervenção pedagógica. De todo modo, para além da dicotomia entre o pedagógico e o biológico na formação em educação física, a interlocução desses dois saberes se tensionam quando se observa a construção

\footnotetext{
${ }^{1}$ Ao longo da tese, ora utilizamos o termo "profissional", ora utilizamos o termo "professor" para indicar o sujeito da Educação Física. Trata-se do uso semântico destas terminologias. A palavra "profissional" aparece quando nos referimos ao sujeito da Educação Física que trabalha na saúde pública de forma genérica. Utilizamos a palavra "professor" quando discutimos alguma aproximação da natureza do trabalho da educação física na saúde pública e que, desde nossa perspectiva, possui características eminentemente educativas e pedagógicas. Entendemos importante esta nota a fim de destacar que não passou pelo escopo do estudo aprofundar nas tensões vividas no campo profissional da Educação Física no que diz respeito às disputas com conselho profissional da área.
} 
histórica dos campos de atuação em educação física, mormente aqueles que contextualizam à Saúde.

Grosso modo, o esporte e a academia de ginástica são hegemonicamente os dois espaços modernos que localizam o trabalho do professor de educação física envolvido com o trabalho em saúde. Entretanto, a "prática pedagógica" do professor de educação física nestes espaços tem assumido características fortemente mercadológicas e passíveis de serem questionadas, uma vez que elas reduzem a ideia de uma concepção de saúde ampliada, nos fazendo refletir, como pensou Carvalho (2004), se a prática de atividade física e esporte por si só geraria saúde? Para além desta discussão é notável que o recrudescimento desses dois espaços conduziu a produção de conhecimento em educação física na focalização dos sujeitos exclusivamente em sua dimensão biológica. Desta forma, boa parte dos estudos da área possui aportes teóricos marcadamente positivistas com ênfase nas pesquisas empírico-analíticas e circunscritas a uma abordagem biológica-fisiológica, haja vista o esporte ter na performance e no alto rendimento seus principais objetivos e a academia de ginástica maximizar irracionalmente o culto ao corpo midiático.

Portanto, são extremamente novos e ainda incipientes os estudos em educação física que busquem pensar a produção de conhecimento em interface com a Saúde por meio de outro paradigma científico. Nesse sentido, o campo da Saúde Pública, no diálogo com a Saúde Coletiva, sugere uma nova perspectiva de avanço científico para a área que potencializa o surgimento de articulação entre os saberes biológicos, pedagógicos, políticos, culturais e sociais nos cursos de formação em educação física com vistas a uma intervenção ampliada de prática pedagógica, também na Saúde.

A recente incursão do professor de educação física em alguns programas do SUS iniciou estudos que aproximam a Educação Física à Saúde Pública, mesmo sendo um campo de atuação extremamente novo na área. Entretanto, o debate (crítico) da educação física na Saúde já havia sido iniciado, como pode se observar em Gonçalves (1989), Palma (2001), Carvalho (2001) e Fraga (2001). Este debate contemplava a necessidade de a educação física ampliar a sua forma de atuação frente aos desafios colocados no campo da Saúde Pública e seus 
emergentes programas. Sobre isso, a tese a ser defendida é de que, do ponto de vista epistemológico, a educação física precisaria se apropriar de referenciais teóricos das ciências sociais ao invés de permanecer refém aos marcos das ciências biológicas. Desta forma, foi inevitável uma aproximação da área com a Saúde Coletiva. Vale afirmar que tal aproximação tem contribuído enormemente para uma inserção da educação física de maneira comprometida socialmente com os anseios da Saúde Pública - mesmo que isso ocorra de forma bastante tímida.

A Saúde Coletiva contribuiu para a educação física ampliar sobremaneira o seu olhar sobre como compreender a Saúde. A compreensão do conceito ampliado de saúde se deu a partir do relatório final da $8^{\text {a }}$ Conferência Nacional de Saúde de 1986, onde se inscreve que em seu sentido mais abrangente, a saúde é resultante das condições de alimentação, habitação, educação, renda, meio ambiente, trabalho, transporte, emprego, lazer, liberdade, acesso e posse de terra e acesso a serviços de saúde. É, assim, antes de tudo, o resultado das formas de organização social da produção, as quais podem gerar grandes desigualdades nos níveis de vida (FLEURY, 1992). Entretanto, salta aos olhos como tal conceito "ampliado" não circunscreve a questão do emocional como elemento preponderante para uma "condição" de saúde. Em nossa opinião, isso irá se desdobrar nos estudos da educação física que tomam como referencial teórico a Saúde Coletiva, como é possível observar em Bagrichevsky (2007), Ceccin e Bilibio (2007) e Wachs e Fraga (2009). O que se pretende dizer é que mesmo quando o foco é o social, o sujeito não pode ser anulado. O que não significa que haja uma intencionalidade dos estudos em anular os sujeitos. No entanto, é fato que o sujeito, nos termos da subjetividade, não está contemplado nos estudos, pois se fala do social como um ente externo aos sujeitos e, às vezes, incorre-se no equívoco de estabelecer um discurso objetivista e determinista quando se defende numa relação causa-efeito quais aspectos objetivos do social condicionam e determinam uma realidade. Quando isso é sugerido, aí sim o sujeito é anulado.

Não há dúvidas de que o domínio de um conceito de saúde a partir de uma compreensão ampliada tornou-se aspecto fulcral para o amadurecimento epistemológico da educação física na sua relação com a Saúde e que, 
certamente, o discurso oriundo da teoria crítica assaz favoreceu o enfrentamento com os movimentos de uma educação física conservadora no campo da saúde, onde o sujeito nunca existiu (salvo o sujeito biológico). Entretanto, é mister continuar avançando e ampliando as apropriações da área. Por certo, pensamos que um caminho é enfrentar os desafios que se apresentam como grandes questões: a) como a educação física pode, a partir de uma perspectiva crítica, contribuir para um projeto de Saúde Pública no Brasil?; b) como a educação física pode se legitimar a partir de sua própria constituição epistêmica e em diálogo com outras ciências ao se inserir nos espaços da Saúde Pública?; c) qual o papel da educação física nos espaços da Saúde Pública?; d) a educação física é mesmo imprescindível nos espaços da Saúde Pública? Embora seja possível perceber um profícuo debate teórico da educação física produzido ao longo do início do século XXI (CARVALHO, 2001, 2005, 2006; PALMA, 2001; BAGRICHEVSKY, ESTEVÃO, 2005; QUINT et. al., 2005), tais questões, ainda que genéricas, estão longe de serem respondidas. Obviamente não temos a pretensão de responder tais questões nesse trabalho, mas, sugerimos que um bom caminho na busca das respostas é o de colocar à prova à empiria da área nos espaços da Saúde Pública, ou seja, buscar os espaços de inserção do trabalho da educação física e fazê-la passar pelo crivo científico e assim, fortalecer ainda mais as construções teóricas da área nesse campo. É nesse sentido que se apresentou e se realizou esta pesquisa em nível de doutorado.

Um campo bastante descoberto e que demonstra uma perspectiva de trabalho de grande potencial para a educação física é o da saúde mental, percebido em Wachs e Fraga (2009) e Abib et. al. (2010) quando o trabalho da educação física foi materializado nos Centros de Atenção Psicossocial (CAPS). Tais iniciativas sugerem uma continuidade de estudos que tomam o CAPS como lócus privilegiado para uma educação física que se pretende crítica quando subjaz uma política paradigmática no âmbito da reforma psiquiátrica brasileira.

Assim, o escopo deste estudo foi o de pensar as configurações subjetivas (GONZÁLEZ REY, 1997, 2005a) da atuação de profissionais de educação física no campo da Saúde Pública, mais especificamente no interior dos CAPS. Na esteira desse primeiro objetivo, tencionou-se entender como emergem sentidos 
subjetivos na atividade do profissional de educação física quando este se insere no contexto da saúde mental e trabalha junto aos sujeitos com severos transtornos psíquicos. Ademais, explicar a subjetividade social configurada no CAPS a partir da relação multiprofissional dos vários agentes de saúde incorporados ao trabalho na saúde mental. Por fim, foi inevitável não explorar como os sujeitos atendidos em CAPS produzem sentidos subjetivos nas relações com o trabalho dos profissionais de educação física e o que isso implica para a área na sua pretensão de se legitimar no campo da saúde pública e especificamente na saúde mental.

Todas estas questões engendravam a necessidade de um aporte teórico que sustentasse os diversos elementos que se apresentam imbricados no cerne da relação da intervenção pedagógica da educação física, do projeto terapêutico do CAPS e sua equipe multiprofissional (médico, psicólogo, enfermeiro, fonoaudiólogo, assistente social, pedagogo, etc) e do ancoradouro político assegurado pelo Sistema Único de Saúde (SUS). Nesse sentido, o estudo se apoiou na Teoria da Subjetividade de Gonzáles Rey, entendendo que os aspectos elencados acima se situam numa estrutura complexa que não se desvela por meio da fragmentação, pelo contrário, carece de um arcabouço teórico que produza esteio para uma atuação eminentemente social e subjetiva da parte do profissional de educação física no campo da saúde pública e que possa concebêlo não como um sujeito que apenas "prescreve exercícios" ou faz "avaliações biométricas", mas que no contexto da saúde mental possa contribuir para a consolidação de processos de aprendizagem e desenvolvimento humano no âmbito da promoção da saúde.

O CAPS se constitui como desdobramento da Reforma Psiquiátrica no Brasil iniciada na década de 1970 (AMARANTE, 1994) e aponta para uma completa reestruturação do padrão de atendimento à saúde mental, revogando o modelo manicomial em prol de uma rede integral de assistência aos sujeitos que apresentam transtornos de ordem psíquica. O CAPS faz parte da rede de ações do SUS, política que desenvolve uma série de programas que reivindicam ao Estado o dever de ofertar à sociedade um serviço de saúde como direito constitucional (BRASIL, 2004). 
Nos últimos anos, as Conferências Nacionais de Saúde Mental vêm sinalizando a importância de expandir e diversificar as equipes multiprofissionais no CAPS, de forma a ampliar as práticas em saúde mental entre os profissionais tradicionais do campo da saúde (médico, enfermeiro, psicólogo, odontólogo, etc) requerendo a presença de outros profissionais como professores de educação física, arte terapeuta, musicoterapeuta, psicopedagogos, etc, "de modo a assegurar a interdisciplinaridade da atenção" (SUS/CNS, p.72) no CAPS. Diante disso, observa-se que alguns gestores públicos, percebendo esta demanda e necessidade dos CAPS, elaboram portarias que paulatinamente autorizam a contratação desses profissionais para os quadros das Secretarias de Saúde. No caso da educação física, mesmo de forma tímida, já é possível notar a inserção deste profissional junto ao trabalho de cuidado à saúde mental nos CAPS.

Tendo em vista a presença do professor de educação física assegurada no serviço público de saúde com foco de atuação na saúde mental é mister tentar entender como se dá a contribuição deste profissional formado para a dinâmica do trabalho pedagógico que passa agora a participar de um projeto terapêutico em saúde que busca construir/consolidar um modelo reformista na dinâmica da reabilitação de sujeitos com transtorno mentais. Nessa teia complexa no qual se observa o professor de educação física, o trabalho interdisciplinar por meio de equipe multiprofissional e as diretrizes políticas que condicionam uma política pública, é fundamental sujeitar o fenômeno a um referencial teórico que o olhe em sua totalidade. Nesse sentido, a observação de Mitjáns Martínez (2005, p.20) ao pensar as categorias subjetividade social e subjetividade individual da Teoria da Subjetividade de González Rey é pertinente:

As subjetividades social e individual constituem-se mutuamente. Não é possível considerar a subjetividade de um espaço social desvinculada da subjetividade dos indivíduos que a constituem; do mesmo modo, não é possível compreender a constituição da subjetividade individual sem considerar a subjetividade dos espaços sociais que contribuem para a sua produção.

Ao pensar a relação entre complexidade e subjetividade a partir da Teoria da Subjetividade de González Rey, Mitjáns Martínez (2005) confessa seus 
"incômodos" quando se depara com os dois termos incrustados no discurso recentemente usual entre psicólogos, educadores e especialistas das ciências sociais. Mitajáns Martínez (2005) entende que boa parte da opção pelos termos complexidade e subjetividade - muitas vezes estão calcados numa compreensão que permanece junto ao senso comum, geralmente circunscrevendo o discurso a um entendimento bastante superficial e distante da produção teórica que os sustenta. Sendo este o argumento justificador de sua análise, a autora avança no cotejamento da Teoria da Subjetividade de González Rey e a Teoria da Complexidade de Morin.

Ao pensar os pontos de convergência entre a complexidade e a subjetividade, Martínez (2005) favorece a compreensão de que a Teoria da Subjetividade de González Rey, mesmo orientada inicialmente aos estudos da Psicologia, pode oferecer subsídios teórico-metodológicos que sustentem estudos entre todas as ciências humanas. Nesse sentido, pensar a subjetividade como esteio teórico às pesquisas em educação física que buscam compreender fenômenos complexos certamente legitimam cientificamente as produções alargando as tradições científicas da área, porém, segundo outro paradigma.

A proposição da subjetividade como marco teórico deste estudo encontra ressonância quando se observa quais os anseios presentes no bojo da pesquisa. Ao passo em que se pretendeu pensar a atuação do professor de educação física em relação à saúde mental, algumas construções de González Rey (2005a) afluem antecipadamente em apontamentos que contribuem do ponto de vista epistemológico para este debate. É o caso, por exemplo, do conceito de sentido subjetivo, o qual estabelece relação com o processo de subjetivação. Para González Rey (2005c, p.43-44) o sentido subjetivo se manifesta como

[...] a unidade dos aspectos simbólicos e emocionais que caracterizam as diversas delimitações culturais das práticas humanas em um nível subjetivo. Tais aspectos simbólicos e emocionais se integram recursivamente na delimitação do sentido subjetivo, no qual um evoca o outro sem que um seja a causa do outro. 
Continuando, o autor esclarece que o sentido subjetivo revela uma possibilidade de perceber a realidade, através dessas complexas unidades simbólico-emocionais, nas quais o contexto social e a história dos sujeitos são os elementos fundamentais em sua constituição.

Duas outras categorias da teoria de González Rey se mostram importantes no que diz respeito à fundamentação teórica e à natureza do estudo. Trata-se dos conceitos de subjetividade individual e subjetividade social. Sobre a primeira, o autor destaca que "a subjetividade individual representa os processos e formas de organização subjetiva dos indivíduos concretos. Nela aparece a história única de cada um dos indivíduos, a qual, dentro de uma cultura, se constitui em suas relações pessoais" (GONZÁLEZ REY, 2005a, p.241). Acerca disso, o autor defende que é o sujeito que compreende a subjetividade individual quando este se relaciona de diversas formas com o contexto social por meio de diferentes práticas. Já a subjetividade social compreende

[...] uma produção simbólica e de sentido que constitui um nível diferente de organização ontológica da sociedade. Ela não é a reprodução dos complexos processos objetivos - infraestruturas, de relação, de organização, etc., que caracterizam a sociedade e dentro dos quais eles são gerados, mas uma nova forma de constituição do tecido social em relação aos inúmeros aspectos objetivos que caracterizam a vida das pessoas nos diversos espaços da vida social, cuja articulação como sistema se dá precisamente nos sentidos e significados que circulam de forma simultânea nos espaços sociais e nos sujeitos que os constituem. (GONZÁLEZ REY, 2005a, p.209).

A partir destas considerações, a especificidade da subjetividade social está na geração de aspectos que deem visibilidade sobre as diferentes instituições e processos subjetivos da sociedade que se constituem a partir das organizações políticas, econômicas e sociais (GONZÁLEZ REY, 2005a). Entender como ocorrem as complexas produções de sentidos subjetivos no interior desses processos nas organizações é um objetivo recorrente da categoria da subjetividade social. Nesse sentido, os 
[...] atos do sujeito em um espaço social concreto estão contidos processos e consequências de outros espaços sociais que the afetam de forma simultânea. É essa trama de espaços sociais interligados, configurados na dimensão subjetiva de pessoas, grupos e instituições, o que define a subjetividade social (GONZÁLEZ REY, 2007, p.167).

Para a pesquisa é interessante destacar o ganho de valor heurístico que a Teoria da Subjetividade de González Rey vem trazendo para a psicologia e para as ciências aplicadas, uma vez que a subjetividade se tornou o eixo epistemológico da pesquisa. González Rey (2005a, p.210) observa que as categorias conceituais apresentadas "não são úteis somente pelo que significam de forma direta, mas pelas consequências que a partir de seu uso se veem na investigação e nas práticas profissionais". Portanto, tornam possíveis integralizar problemas que se apresentam na singularidade dos sujeitos e que também estão associados às questões complexas em função de múltiplos elementos sociais. Flexíveis, portanto, aos interesses de outras ciências que buscam outros objetos de estudo. Isso por si só já torna tal aproximação - Educação Física e Teoria da Subjetividade - bastante auspiciosa.

Pensar estas questões com mais profundidade foi o anseio fundante da iniciativa de elaboração desse estudo e que se efetivou junto ao Programa de Pós-Graduação em Educação, em nível de doutorado e ora se apresenta como tese a ser defendida na linha de pesquisa "Escola, aprendizagem, ação pedagógica e subjetividade na educação", tomando como eixo de interesse "O sujeito que aprende, processos de aprendizagem e saúde".

A tese foi organizada inicialmente num capítulo teórico que procura fazer uma aproximação a alguns temas importantes ao estudo, quais sejam a teoria da subjetividade numa perspectiva cultural-histórica, a educação física e sua relação com o campo da saúde pública e a saúde mental, no que diz respeito aos movimentos epistemológicos e de intervenção engendrados a partir da reforma psiquiátrica brasileira.

Assim, a fundamentação teórica foi circunscrita em três seções. A primeira seção aborda a Teoria da Subjetividade numa perspectiva cultural-histórica ou Teoria da Subjetividade de González Rey e discute a sua inserção no campo da 
educação e da saúde. A segunda seção traz inicialmente breve excurso histórico da relação da educação física com a Saúde para abordar na sequência o amplo debate contemporâneo da área na Saúde a partir de uma perspectiva crítica no qual seu corolário possui implicações epistemológicas e disputas políticas no interior da educação física. Na sequência, promove-se um esforço ensaístico de pensar os desdobramentos possíveis da Teoria da Subjetividade para uma educação física que ao mesmo tempo procura entender e se inserir na saúde pública, no caso da educação física, por meio do trabalho na saúde mental. $A$ terceira e última seção da fundamentação teórica procura apresentar de forma breve, aspectos históricos da reforma psiquiátrica brasileira, bem como discutir os elementos filosóficos e epistemológicos que a constituíram por meio da saúde coletiva. Esta seção se encerra com um debate a partir da incipiente produção científica da educação física em interface à saúde mental. Neste capítulo de fundamentação teórica foi possível justificar a presença da investigação num programa de pós-graduação em Educação e aprofundar a tensa discussão da educação física na Saúde iniciada en passant nessa introdução.

A seguir, a tese encaminha um capítulo de metodologia. A opção foi de trazer na forma de prolegômenos do método, esclarecimentos sobre a Epistemologia Qualitativa, expressão teórico-metodológica e epistemológica da Teoria da Subjetividade de González Rey, realizando um breve cotejamento com o pensamento do filósofo austríaco Paul Feyerabend acerca da crítica ao racionalismo. Adiante, passa-se a apresentar o processo de construção do cenário de pesquisa, momento importante e caro às pesquisas que se apoiam na Epistemologia Qualitativa. Os dois CAPS que se constituíram cenário do estudo são apresentados de forma genérica a fim de preservar a identidade dos CAPS, segundo orientação de padrões éticos da pesquisa na saúde. Entretanto, os aspectos estruturantes do CAPS são levados em consideração com o objetivo de melhor caracterizar este espaço social da saúde mental brasileira. Os instrumentos de pesquisa bem como as estratégias de organização da informação segundo a perspectiva da Epistemologia Qualitativa são destacados e acentuam a subjetividade do pesquisador e o processo de caráter criativo demandado por 
esta opção metodológica. Tais informações foram organizadas em seções próprias neste capítulo metodológico.

O terceiro capítulo trata da construção da informação e procurou gestar um modelo teórico que visasse uma abertura à inteligibilidade do fenômeno que se pretendia investigar. Seguindo a orientação de produzir um sistema teórico que abordasse nossos objetivos, a construção da informação foi organizada em dois eixos temáticos, produzidos com base em cada CAPS investigado. $O$ primeiro eixo identifica e discute os dilemas e desafios da educação física na saúde mental por meio das configurações subjetivas da atuação da educação física no CAPS. O segundo eixo temático aborda de forma ressignificada tais configurações subjetivas, enaltecendo as emergências dos sujeitos que vivem as práticas corporais como produção de sentido subjetivo e, assim, podem promover alternativas de vida para o enfrentamento do sofrimento e do transtorno mental. Por fim, as conclusões oferecem uma abertura à educação física para repensar as formas de legitimação da área no cenário da saúde mental brasileira bem como enaltece a aproximação epistemológica da área com a teoria da subjetividade numa perspectiva cultural-histórica. 


\section{II - FUNDAMENTAÇÃO TEÓRICA}

[...] será que vale mais estudar extensivamente o conjunto de elementos pertinentes do objeto construído, ou antes, estudar intensivamente um fragmento limitado desse conjunto teórico que está desprovido de justificação científica? A opção socialmente mais aprovada, em nome de uma idéia ingenuamente positivista de precisão e de "seriedade" é a de "estudar a fundo um objeto muito preciso e bem circunscrito", como dizem os orientadores de teses. (Seria bastante fácil mostrar como virtudes pequenoburguesas de "prudência", de "seriedade", de "honestidade" etc., as quais poderiam exercer-se na gestão de uma contabilidade comercial ou em um emprego administrativo, se converterem aqui em "método científico").

Pierre Bourdie 


\section{SUBJETIVIDADE, EDUCAÇÃO E SAÚDE}

\section{A Teoria da Subjetividade numa perspectiva cultural-histórica: primeiras aproximações}

De antemão, é necessário precisar que a subjetividade a qual tematizamos neste capítulo e que se apresenta como referencial hegemônico e núcleo teórico desse estudo é, por nós compreendida, um conceito que possui base científica e uma teoria em amplo desenvolvimento. Há aqui o interesse em circunscrever ideias a partir da Teoria da Subjetividade numa perspectiva cultural-história ou Teoria da Subjetividade de González Rey. Para tanto, destacaremos a seguir seus pressupostos histórico-filosóficos e sua construção epistemológica situada na Psicologia e que vêm se inserindo nas ciências humanas e sociais ao longo dos últimos trinta anos.

$\mathrm{Na}$ psicologia, a Teoria da Subjetividade contrapõe o amplo desenvolvimento dos estudos segundo um modelo científico positivista que se baseia em princípios objetivistas e que desdobram visões reducionistas, deterministas, quantitativas e mecanicistas da psique humana (GONZÁLER REY, 1997, 2005a). Em meio a esta perspectiva tradicional de ciência, a psicologia negou ao longo de sua trajetória acadêmico-científica uma compreensão de subjetividade ampliada e em consonância aos aspectos sociais e culturais integrados aos processos psíquicos. Pontualmente, a crítica de González Rey (2005a) e compartilhada por Danzinger (1990), Rose (2011) e Gergen (2009), alerta que o paradigma cartesiano-newtoniano está tão fortemente arraigado à cultura ocidental que nenhuma das ciências sociais permaneceu imune às suas influências e em particular à psicologia, mesmo quando é sabido que tal paradigma tenha sido superado nas ciências naturais a partir do advento do Princípio da Incerteza de Heinsenberg e a Teoria da Relatividade de Einstein. Segundo o autor, o corolário disso - na psicologia - é o esgotamento de uma pretensão científica que se traduza em teoria. Esse panorama histórico-científico na psicologia introduziu o pensamento de que há uma divisão entre a produção teórica e a investigação científica. González Rey (2005a) relembra que os principais sistemas teóricos produzidos na psicologia não se configuravam 
intencionalmente como campos de investigação científica, vide Freud ${ }^{2}$ e Lacan. Marcada pelo viés positivista de ciência, a investigação científica da psicologia permaneceu fiel aos limites do verificacionismo indutivista dos fenômenos empíricos. Nesse sentido, González Rey (2005a, p.70) observa que

[...] a produção da "psicologia científica" era totalmente ateórica, apoiando-se linearmente na produção de dados em relação aos quais a produção de ideias passou a ser considerada de forma pejorativa, pois a rejeição à metafísica especulativa e a impossibilidade de uma opção epistemológica que permitisse resgatar o teórico, deixando fora o especulativo, terminou em uma rejeição ao lugar das ideias na produção do pensamento. Desta forma, a produção de categorias tinha um caráter essencialmente empírico, no qual apareceram os conceitos como "envolturas" de realidades empíricas.

Esse contexto epistemológico da psicologia inspirou González Rey a romper com esta ordem que obliterava contundentemente o caráter cultural e histórico da psique humana. A subjetividade será então a expressão qualitativa do esforço teórico de "reconceituar o fenômeno psíquico em uma ontologia própria, específica do tipo de organização e processos que o caracterizam" (GONZÁLEZ REY, 2005a, p.73). Isso só foi possível em face à apropriação da dialética pelos psicólogos, situados em condições sociais específicas, mormente às materializadas pela revolução russa. A psicologia soviética foi, portanto, precursora no desenvolvimento de uma psicologia que ampliara a compreensão dos fenômenos psicológicos condicionando-os aos aspectos sociais, históricos e culturais. A constituição da subjetividade em González Rey como "uma representação da psique em uma nova dimensão complexa, sistêmica, dialógica e dialética, definida como espaço ontológico ${ }^{3 " ;}$ teve, no pensamento de Vygotsky,

\footnotetext{
2 "A própria orientação naturalista, por exemplo, de Freud, que representou um modelo muito influente nos sistemas teóricos de fundamento clínico, nunca elaborou sua experiência de uma perspectiva epistemológica que the permitiria o desenvolvimento de posições metodológicas alternativas" (GONZÁLEZ REY, 2005a, p.70).

3 A compreensão do termo "ontológico" na Teoria da Subjetividade de González Rey se difere do conceito racionalista tradicional que expressa o ontológico como essência última de um fenômeno.
} 
Rubinstein e Buzhovich, reconhecidamente expoentes da psicologia soviética, suas maiores influências (GONZÁLEZ REY, 2005a, p.75).

A apropriação da dialética e do marxismo em Vygotsky e Rubinstein será um marco na psicologia uma vez que ela situa o início do fim das grandes dicotomias da área como o cognitivo e o afetivo, o consciente e o inconsciente, o social e o individual. Esta última, em específico, guarda uma importante e polêmica contribuição desses dois vanguardistas da psicologia soviética. O social passa a ser um elemento importante na compreensão dos processos psicológicos. Entretanto, ao viver as contradições dos desdobramentos da revolução - expressadas no stalinismo - a psicologia russa paulatinamente vai conferindo ao social o núcleo constituinte do psíquico numa clara acepção de um determinismo mecanicista que imputa o social como a causa da psique. Este fato marcou a obra de Vygotsky num determinado período, mas ele conseguiu superála mais adiante a partir de sua compreensão dialética que encerra a complexa relação entre o social e os processos psicológicos. Por isso, vale dizer que a "sua (de Vygotsky) representação complexa do social não está pronta a priori; ela vai se desenvolvendo no processo da própria obra do autor russo, e na especificidade dos desafios que sua própria produção vai gerando" (GONZÁLEZ REY, 2012a, p.33). Desta forma, González Rey (2012a) prefere entender Vygotsky como um autor "vivo" com uma impressionante vocação para o teórico e que apresentou contradições no decorrer do brilhantismo de suas ideias sempre implicadas socialmente face às influências marxistas não dogmáticas que possibilitou deixar como legado uma teoria geral da psicologia. A expressão "vivo" significa dizer que o pensamento vygotskiano tem como maior característica a abertura de infinitas possibilidades de produção teórica. A brevidade de sua vida não o deixou dar continuidade as suas auspiciosas ideias. Assim, é um equívoco interpretar sua obra, ou mesmo uma parte dela, como uma teoria cerrada, passível de ser aplicada. Tal compreensão distorce o que em Vygotsky há de mais caro: a sua relação com a dialética.

No caso, em González Rey, o termo se consagra em se referir a um fenômeno psíquico de uma realidade que se difere qualitativamente de outras formas de realidade. 
Neste entendimento, essa compreensão de González Rey (2012a, 2012b) gestada a partir de uma intensa arqueologia da obra de Vygotsky, foi condição sine qua non para o desenvolvimento da categoria subjetividade em seu pensamento. Entretanto, a Teoria da Subjetividade de González Rey não pode ser considerada um epifenômeno da Teoria Histórico-Cultural de Vygotsky. Portanto, não é possível pensar o desenvolvimento da subjetividade situada em González Rey em vários trabalhos (1997, 2005a, 2005b, 2005c, 2005d, 2007, 2012a, 2012b) sem discorrer sobre as críticas que o autor fez a alguns períodos e ideias de Vygotsky, mas que são na verdade, fruto de uma produção de sentido subjetivo do referido autor e que, recursivamente, vem a representar sua própria produção teórica. Como forma de exemplificar e ratificar essa argumentação é mister registrar a seguinte passagem, mesmo que extensa:

Rubinstein dá um passo muito importante quando escreve: "A dimensão social não se mantém como fato externo com respeito ao homem: ela penetra e desde dentro determina sua consciência" (RUBINSTEIN, 1967, p19). Nesta afirmação tão simples em aparência, Rubinstein coloca dentro do repertório linguístico possível da psicologia da época a unidade entre o social e o psicológico, rompendo com a divisão mecanicista da externalidade de um em relação ao outro. Esta é uma colocação compartilhada também por Vygotsky, e que representa uma importante premissa para uma compreensão dialética da relação entre o sujeito individual e a vida social que, como veremos a seguir, foi uma das intenções principais desses pioneiros da psicologia soviética.

A dialética do individual e do social permitiu superar o conceito de indivíduo como inerente para espécie, e favoreceu a compreensão da condição singular de sujeito, possível somente a partir da compreensão do caráter subjetivo de sua constituição psicológica. Nas fundamentações, tanto de Vygotsky como em Rubinstein, o nível do singular, do sujeito concreto, não desapareceu, e sim foi colocado no nível da concretização de sua ação social, e não como natureza inerente à individualidade.

Contudo, um dos temas polêmicos até hoje é o processo de formação do psíquico a partir do social, a definição de quais são os processos implicados no desenvolvimento da psique histórica e culturalmente configurada. Aqui se faz necessário esclarecer que, tanto Vygotsky como Rubinstein, ao enfatizarem que o social não resulta em uma dimensão externa, não conseguem explicar e

\footnotetext{
${ }^{4}$ In RUBINSTEIN, S. L. El ser y la consciencia. Havana: Edición Revolucionaria, 1967.
} 
aprofundar todas as consequências desse aporte, o qual, em si mesmo, já representa uma forte ruptura com as representações que dominavam a psicologia da época.

Vygotsky tentou solucionar a questão por meio do conceito de interiorização, mas como temos afirmado em outros trabalhos $(1985,1995,1997)^{5}$, a subjetividade não se internaliza, não é algo que vem de "fora" e que aparece "dentro", o que seria uma forma de manter a dualidade em outros termos. Na minha opinião, tratase de compreender que a subjetividade não é algo que aparece somente no nível individual, mas que a própria cultura dentro da qual se constitui o sujeito individual, e da qual é também constituinte, representa um sistema subjetivo, gerador de subjetividade. Temos de substituir a visão mecanicista de ver a cultura, sujeito e subjetividade como fenômenos diferentes que se relacionam, para passar a vê-los como fenômenos que, sem serem idênticos, se integram como momentos qualitativos da ecologia humana em uma relação de recursividade. (GONZÁLEZ REY, 2005a, p.77-78).

De todo modo, o que está para além da crítica é o reconhecimento de que uma parte da história da psicologia soviética enfrentou uma tendência ao reducionismo sociológico que impactou os estudos dos processos psicológicos com a lógica de forçar o enfoque do psíquico na expressão de alguma materialidade, fato que recebia uma forte influência de interpretação mecanicista do marxismo da hegemonia política da União Soviética. Outrossim, o tema da subjetividade permaneceu eclipsado no prodigioso pensamento da psicologia soviética que convivia ciente dos significados da dialética para o desenvolvimento rumo a uma totalidade da compreensão dos processos psicológicos, mas que era compelida a se expressar num código em acordo às pressões políticas da época (GONZÁLEZ REY, 2012b). Vygotsky não permaneceu imune a este contexto, entretanto, sua obra transcende qualquer tipo de amarras ideopolíticas, quando se observa que, seguindo a melhor das tradições marxistas, seu pensamento baseou-se na conformação da psique como sistema em desenvolvimento, "que tem formas de organização que estão além das formas imediatas de comportamento do sistema" (GONZÁLEZ REY, 2005c, p.34). Em Vygotsky, as formas de organização da psique, compreendidas a partir de um sistema dialético,

\footnotetext{
${ }^{5}$ In GONZÁLEZ REY, F. Personalidad, comunicación y desarrollo. Havana: Pueblo y Educación, 1995. GONZÁLEZ REY, F. Epistemología cualitativa y subjetividade. São Paulo: Educ, 1997.
} 
são constituintes da psicologia científica. Essa compreensão ilativa do pensamento vygotskiano resultou a gênese da subjetividade em González Rey (2005c, p.34):

\begin{abstract}
Vygotsky sempre representou a psique como sistema, mesmo que, em diferentes ocasiões, mudasse sua representação sobre tal sistema. Assim, em determinado momento concreto de sua obra, identificou o sistema com o desenvolvimento e definiu, como sua unidade constitutiva, a vivência; em outro momento, considerou a consciência como sistema, cuja unidade constitutiva foi o significado; finalmente, falou do sentido, mas não chegou a desenvolver o sistema no qual estaria inserido o sentido. $\mathrm{Na}$ nossa opinião, o sistema que daria conta do sentido seria precisamente a subjetividade, por esta ter todas as características de um sistema complexo.
\end{abstract}

Desta forma, em González Rey (2005c, p.35) encontramos a seguinte definição para a subjetividade numa perspectiva histórico-cultural:

[...] um sistema não fundado sobre invariantes universais que teria como unidade central as configurações de sentido que integram o atual e o histórico em cada momento de ação do sujeito nas diversas áreas de sua vida. Dessa forma, a historicidade dos sistemas de sentido subjetivo aparece como momentos de sentido da ação atual do sujeito, momento este definido pela organização subjetiva da personalidade; mas, ao mesmo tempo, pelo caráter processual da subjetividade o qual se expressa na produção atual de sentidos subjetivos no percurso das ações do sujeito.

O desenvolvimento da teoria de González Rey permeou a produção de algumas categorias que "permanecem pressionadas" pela continuidade das pesquisas e estudos do autor na psicologia e nas ciências antropossocia s, o que é importante acentuar uma vez que seria contraditório a partir da compreensão epistemológica, incurso do referido autor, tornar hermético suas elaborações teóricas.

Para González Rey (2005c) a categoria sujeito está implicada obrigatoriamente em qualquer estudo em torno da subjetividade. Inclusive, muitas de suas críticas direcionadas às várias correntes epistemológicas da psicologia das clássicas às pós-modernas - se dão pelo obscurecimento ou completa 
anulação do sujeito. $\mathrm{O}$ autor refuta a compreensão de sujeito situada no racionalismo cartesiano - "o sujeito da razão" - ou no pós-estruturalismo - "o sujeito do discurso" - e incorpora a preponderância da emocionalidade como um elemento ontológico à categoria sujeito. "A emoção é uma condição permanente na definição do sujeito" (GONZÁLEZ REY, 2005a, p.236). A categoria sujeito compõe a base da subjetividade por ser ela condição de expressão de sentidos subjetivos produzidos pelo homem que se manifesta por meio das características dialéticas do social e o do individual.

A emoção, aspecto que determina qualitativamente o sujeito, se coaduna aos processos simbólicos percebidos no sujeito - que se dá na investigação científica - e que constitui a categoria sentido subjetivo. Os sentidos subjetivos "representam complexas combinações de emoções e de processos simbólicos que estão associados a diferentes momentos da vida" (GONZÁLEZ REY, 2005c, p.41) e assim é definido:

[...] a unidade dos aspectos simbólicos e emocionais que caracterizam as diversas delimitações culturais das práticas humanas em um nível subjetivo. Tais aspectos simbólicos e emocionais se integram recursivamente na delimitação do sentido subjetivo, no qual um evoca o outro sem que um seja a causa do outro. (GONZÁLEZ REY, 2005c, p.43-44).

O escopo do autor ao apresentar estas ideias frente a esta categoria é o de superar qualquer tipo de reducionismo objetivista implicado nas ações dos sujeitos no meio social e tomadas como objeto pelas pesquisas científicas. A ação do sujeito está sempre plurideterminada e se torna inteligível ao nível do teórico que por sua vez, é sempre uma construção-interpretativa do pesquisador. Ademais, há sempre formas mais complexas de organização dos processos psicológicos, os quais González Rey (2005c) prefere denominar como configurações subjetivas.

As configurações subjetivas organizam a subjetividade como um sistema complexo (GONZÁLEZ REY, 2005c). Segundo o autor, elas "são relativamente estáveis por estarem associadas a uma produção de sentidos subjetivos que 
antecede ao momento atual da ação do sujeito". No entanto, alerta González Rey (2005c), o sentido subjetivo nunca é determinado a priori, motivo pelo qual a produção do sentido subjetivo se dá sempre no percurso da ação ao sofrer o tensionamento das configurações subjetivas. Por ter caráter sistêmico, a categoria configuração subjetiva é potencializadora à compreensão dos processos de subjetivação das atividades do sujeito. Outras duas categorias fundamentais em González Rey na produção teórica em torno das diversas expressões do sujeito é a subjetividade individual e a subjetividade social.

"A subjetividade individual representa os processos e formas de organização subjetiva dos indivíduos concretos" (GONZÁLEZ REY, 2005a, p.241). Assim, a subjetividade individual expressa a história singular dos sujeitos contextualizadas numa cultura circunscrita nos mais diversos espaços sociais vividos. A personalidade é um conceito importante na compreensão e no desenvolvimento da categoria subjetividade individual. Entretanto, este conceito segundo uma perspectiva cultural-histórica deixa de ter uma natureza intrapsíquica, passível de ser medida por testes psicológicos, para ser compreendida como uma configuração subjetiva do sujeito, fruto das experiências históricas e sociais. A assunção de uma organização sistêmica da personalidade na subjetividade individual irá sugerir uma inter-relação entre subjetividade individual e subjetividade social para a compreensão do sentido subjetivo nas ações dos sujeitos.

Em González Rey (2005a) verifica-se a ideia de que a subjetividade não compreende só o sujeito individual, sendo necessário entender a dimensão subjetiva dos diferentes processos e instituições sociais. Além disso, a subjetividade social representaria o microcosmo vivido pelos sujeitos que perfazem uma cultura que é produto histórico, mas que às vezes possui diferenças importantes em determinados contextos. Uma escola, por exemplo, pode constituir uma subjetividade social distinta da cultura geral de um sistema de educação de uma sociedade. Com efeito, González Rey (2005a, p.209) define subjetividade social como 
reprodução dos complexos processos objetivos - infra-estruturais, de relação, de organização, etc., que caracterizam a sociedade e dentro dos quais eles são gerados, mas uma nova forma de constituição do tecido social em relação aos inúmeros aspectos objetivos que caracterizam a vida das pessoas nos diversos espaços da vida social, cuja articulação como sistema se dá precisamente nos sentidos e significados que circulam de forma simultânea nos espaços sociais e nos sujeitos que os constituem. (GONZÁLEZ REY, 2005a, p.209).

A categoria subjetividade social apresenta um valor heurístico importante e que tem oportunizado diferentes áreas do conhecimento a tomar emprestado à Teoria da Subjetividade numa perspectiva cultural-histórica como referencial de estudo. Na psicologia, a categoria alarga a compreensão dos processos psicológicos na disposição em acessar os sujeitos implicados socialmente.

Finalmente, podemos observar que as construções teóricas de González Rey assumem uma apropriação da dialética marxista enriquecida pela absorção do paradigma da complexidade ${ }^{6}$, sendo estes, por conseguinte, os principais esteios filosófico-epistemológicos de sua teoria que reafirmamos se encontrar em curso. O desenvolvimento dela transcendeu a psicologia e cada vez mais tem se inserido nas ciências antropossociais, em especial na educação e na saúde, é isso que passamos a abordar a seguir.

\footnotetext{
${ }^{6}$ Escapou-nos explorar algumas aproximações teóricas do pensamento de Edgar Morin no desenvolvimento da Teoria da Subjetividade de González Rey na mesma proporção da dialética marxista da escola psicológica soviética. Assim fizemos por compreender que Morin não constitui a gênese do pensamento de González Rey, embora seja possível perceber em alguns autores, a procura de se estabelecer nexos entre o pensamento complexo à obra de González Rey, como é o caso de Mitjáns Martínez (2005) e Scoz (2009).
} 


\section{A inserção da Teoria da Subjetividade na Educação e na Saúde}

O destaque dado à inserção da Teoria da Subjetividade de González Rey no campo da Educação e da Saúde não se situa apenas num incremento do número de estudos que abarcam este referencial como núcleo gerador de conhecimento científico. A Educação parece ter encontrado ressonância na subjetividade quando se observa um aumento das pesquisas na temática da aprendizagem e da formação docente, como sugere Scoz, Tacca e Castanho (2012). De modo que numa perspectiva cultural-histórica, a subjetividade possui lastro em várias pesquisas na Saúde (GONZÁLEZ REY, 2004, 2011; SOLON, 2005, GOULART, 2013). Logo, a questão que se coloca é a de refletir sobre como a subjetividade numa perspectiva cultural-histórica inscreve, do ponto de vista qualitativo, aspectos que até então não eram discutidos no campo da educação e da saúde. A fim de encaminhar essa reflexão na educação, um caminho possível é o de abordar os estudos sobre a criatividade como expressão complexa da subjetividade em Mitjáns Martínez $(2006,2012)$ e a categoria "o sujeito que aprende" desenvolvida em González Rey (2006) e explorada por Teles e Cerqueira (2013). Na saúde, apresentamos os estudos sobre modo de vida e o conceito ampliado de saúde em González Rey (2004) e as pesquisas que apontam novos aportes da subjetividade na saúde mental, em González Rey (2011) e Goulart (2013a).

O tema da aprendizagem é recorrente nos estudos da educação e se configura historicamente de forma interdisciplinar. A psicologia, ciência gênese da teoria da subjetividade numa perspectiva cultural-histórica, manteve uma orgânica relação com a educação no que concerne o desenvolvimento das pesquisas em torno da aprendizagem. Entretanto, se analisarmos os termos dessa relação, iremos perceber que as maiores influências da psicologia na aprendizagem estão nos dispositivos do behaviorismo e na teoria psicogenética de Piaget. Na medida em que estas correntes teóricas são indiscutivelmente representantes de uma epistemologia positivista, o corolário de suas contribuições é a ênfase instrumental e operacional na forma de aprender. Na subjetividade depreende-se uma ideia diametralmente oposta a elas. Segundo González Rey (2006, p.30) “a aprendizagem tem uma dimensão subjetiva envolvida com a ação singular do 
sujeito que aprende, na qual participam, em formas de sentido subjetivo, "recortes de vida" que representam as formas em que essa vida se configurou na dimensão subjetiva de cada pessoa".

Parece-nos impossível falar de aprendizagem sem discorrer minimamente de seu par dialético, que é o ensino. A tradição escolar revela um ensino centrado na oferta de um acúmulo de conhecimentos que se apresentam, em muitas vezes, alheios aos sujeitos cognoscentes. Da aprendizagem espera-se a captação desses conhecimentos e a verificação da aprendizagem se dá nos termos da reprodução do conhecimento eleito no ensino. "Assim, a aprendizagem no cenário escolar está orientada mais pela transmissão de conhecimentos verdadeiros, do que pela discussão dos conteúdos apresentados" (GONZÁLEZ REY, 2006, p.31). Vale dizer que o problema não se assenta na apresentação de conteúdo, fato que se entende como um dos papeis da educação formal, ao contrário de algumas correntes construtivistas que imaginam um conhecimento produzido por completo pelos alunos. O problema é que parece existir um conhecimento "certo", "que já está pronto e que o aluno tem que saber, mas nada existe de novo que possa ser acrescentado por ele" (GONZÁLEZ REY, 2006, p.31 - grifo nosso). Assim, o professor continua sendo um mediador fundamental no processo de ensino aprendizagem, no entanto, na perspectiva da subjetividade, precisa-se compreender o aluno como sujeito. E para tornar-se sujeito de sua aprendizagem, o aluno dever ser "[...] capaz de desenvolver um roteiro diferenciado em relação ao que se aprende e se posicionar crítica e reflexivamente em relação à aprendizagem" (GONZÁLEZ REY, 2006, p.40). É nesse sentido que a categoria "o sujeito que aprende" passou a explorar aspectos subjetivos do processo de aprendizagem e que mesmo hoje são pouco reconhecidos nas pesquisas educacionais que tomam como objeto a prática pedagógica na escola. O caráter singular do processo de aprender bem como a compreensão da aprendizagem a partir de uma prática dialógica vão se constituir nos dois aspectos fundamentais dessa orientação teórica. A leitura também é parte central dessa perspectiva na medida em que a participação criativa e reflexiva do aluno deve sempre ser abastecida de novas informações com as quais ele poderá conjugar novas ideias (GONZÁLEZ REY, 2006). 
As bases da epistemologia qualitativa (GONZÁLEZ REY, 1997, 2005b, 2005d) compreende a teoria como modelos de inteligibilidade e sugere que as categorias teóricas não possuem valor instrumental e ensimesmadas, mas ao contrário, elas devem retroalimentar a dinâmica criativa dos pesquisadores que podem a partir delas gerar novas categorias ou novas ideias. Na esteira desse pensamento, apresenta-se o estudo de Teles e Cerqueira (2013) que ousaram explorar a categoria "o sujeito que aprende" a fim de refletir sobre uma forma de atuação docente em consonância a um horizonte ecológico e integrador do ser humano, no qual o aprender se encontra configurado num sistema complexo e não linear. Assim, o anseio de um fazer pedagógico em conformidade às novas formas de aprender solicita uma nova pedagogia, chamada de "pedagogia do si mesmo",

[...] cujo objetivo macro seria uma reflexão conceitual sobre o fazer pedagógico como um convite à pessoa para que ela produza sentidos que despertem o ser sujeito, fazendo-o emergir como o centro do processo de aprendizagem, ou seja, configurar-se como um sujeito que aprende. $O$ desafio conceitual que a pedagogia do si mesmo coloca é pensar que o mais importante no processo de ensino e aprendizagem não são as técnicas e os métodos mecânicos e sim o sujeito e suas produções subjetivas sobre aquilo que pretende aprender, que é algo que sempre extrapola o conteúdo a ser aprendido. (TELES, CERQUEIRA, 2013).

As considerações teóricas de Teles e Cerqueira (2013) foram produzidas à luz de uma experiência de prática pedagógica num curso on-line que integrou a formação continuada de cirurgiões-dentistas. Vale dizer que a tradição desses cursos do ponto de vista dos educandos é de um curso pragmático, atendendo objetivos restritamente técnico-profissionais. Entretanto, o relato da experiência sinaliza bons indícios de que toda e qualquer prática pedagógica necessita um empenho docente no sentido de, ao mobilizar a subjetividade, pensar objetivos que reconheçam uma teia complexa integradora dos conhecimentos a serem explorados; que as práticas pedagógicas sugeridas e produzidas coletivamente 
mantenham relação com uma dinâmica criativa e não mecânica; e, sobretudo, que a produção de sentidos subjetivos constitua a forma de aprender.

De pronto, é possível afirmar que a subjetividade numa perspectiva cultural-histórica advoga a necessidade de que, nos espaços da educação, são prementes as ações educativas que valorizem a emergência do sujeito. Uma premissa importante para isso é de que o sujeito - o aluno - deve ser "capaz de gerar sentidos subjetivos em relação ao que aprende" (GONZÁLEZ REY, 2006, p.40). Dessa forma, a criatividade tem se apresentado como uma categoria-chave nesse processo e que guarda um importante valor teórico-prático na ação docente. Os trabalhos de Mitjáns Martínez $(2006,2012)$ são reconhecidamente excelentes representantes do debate da criatividade desde a perspectiva da subjetividade e da complexidade.

Nos últimos anos, a criatividade tornou-se lugar-comum na escola. Parece que ser criativo é uma virtude e condição do "bom professor", sendo este caracterizado por alguém que inova em seus métodos pedagógicos. Entretanto, vale a reflexão crítica de que criatividade não é sinônimo de novidade e de que muitas práticas pedagógicas ao produzirem o "novo" na sala de aula introduzem um modismo pedagógico com práticas de jogos e dinâmicas que não estão articuladas a uma intencionalidade pedagógica do professor (MITJÁNS MARTÍNEZ 2006).

[...] A criatividade implica a novidade; porém a novidade não é suficiente para se considerar um processo criativo. $O$ valor que 0 novo que se produz tem [...] resulta essencial para a sua consideração como criativo. A introdução de "novidade" no trabalho pedagógico é importante sempre que essa novidade permita novos níveis de aprendizagem e desenvolvimento. (MITJÁNS MARTÍNEZ, 2006, p.71).

Portanto, a criatividade se liga a aprendizagem e tem nela uma relevante característica axiológica no espaço educativo. Para Mitjáns Martínez (2006) a criatividade é um processo complexo da subjetividade humana e que assume uma dupla condição de existência - na subjetividade individual e social - e que expressa de forma recursiva, em uma produção, o "novo" e o "valioso" num 
determinado contexto humano. Os desdobramentos dos estudos da criatividade segundo as orientações da teoria da subjetividade e da complexidade sublinham os ganhos qualitativos na pesquisa educacional e podem ser sintetizados nas razões de se teorizar a criatividade: a) avançar na compreensão das formas complexas da aprendizagem e se constituir como anseio das práticas na escola; b) pensar estratégicas educativas que favoreçam a aprendizagem na escola e que resguardem a constituição integral do sujeito; c) a aprendizagem criativa é um objeto que contribui para diversos campos e reforça a representação complexa de compreensão de mundo (MITJÁNS MARTíNEZ, 2012).

De forma geral, as pesquisas educacionais que procuram dialogar com a teoria da Subjetividade de González Rey representam um importante avanço epistemológico e teórico-metodológico na educação. Trata-se de um momento distinto das contribuições da psicologia que se evidenciaram na segunda metade do século XX no Brasil e a diferença preponderante têm, em nossa opinião, dois aspectos fundamentais. $O$ primeiro tem a ver com a clara ruptura com 0 paradigma cartesiano e estruturalista que permeou a maior parte dos estudos em educação no país, em especial, da prática pedagógica na escola; e o segundo é o fato de que a produção de conhecimento tende sempre a focalizar no sujeito sua condição complexa e sistêmica, ressaltando a dimensão do emocional como aspecto central na produção de subjetividade.

A defesa do paradigma da complexidade repercute no alcance epistemológico da teoria da subjetividade numa perspectiva cultural-histórica e isso se revela em suas contribuições no campo da Saúde. Historicamente, a cientificidade da Saúde sempre esteve atrelada às ciências "duras" uma vez que a biologia se situa como a ciência foco das ações da medicina. Por conseguinte, o marco epistemológico das práticas médicas funda-se nos avanços das ciências biológicas. Mesmo com o advento da medicina social, a hegemonia epistemológica desse campo permaneceu fiel às características do positivismo observadas no movimento higienista e eugenista. Mesmo hoje, vemos a primazia das pesquisas empírico-analíticas no âmbito da epidemiologia. Portanto, as contribuições da subjetividade na saúde estão situadas na contra hegemonia científica e têm procurado recuperar o qualitativo nas pesquisas da saúde. 
Desde a década de 1980 a saúde é objeto de estudo de González Rey pelo viés da subjetividade. A tradicional ideia de saúde como ausência de sintomas já havia se tornado insustentável frente aos diversos avanços da tecnologia médica, bem como os determinantes sanitários que afetavam diretamente a saúde das pessoas. Nesse contexto, González Rey (2004) defendia que o conceito de saúde deveria ser compreendido como um processo e não como um produto, entendendo que a saúde era "um processo qualitativo complexo que define o funcionamento completo do organismo, integrando o somático e o psíquico de maneira sistêmica, formando uma unidade em que ambos são inseparáveis" (GONZÁLEZ REY, 2004, p.1). Ademais, González Rey (2004, p.2-3) percebe como necessária a contextualização da saúde na vida humana, alargando a compreensão de que

na saúde, combinam-se estreitamente fatores genéticos, congênitos, somato-funcionais, sociais e psicológicos. A saúde é uma expressão plurideterminada e seu curso não se decide pela participação ativa do homem de forma unilateral. Esse é um dos elementos que intervém no desenvolvimento do processo, pois muitos dos fatores da saúde são alheios ao esforço volitivo do homem.

Nessas ideias estavam lançadas as bases de um entendimento ampliado de saúde que incorporavam aspectos que estavam para além do individual, projetando o social como parte importante da constituição do conceito de saúde. Em nossa opinião, o pensamento de González Rey no tocante à saúde, aproximase aos constructos teóricos da Saúde Coletiva que se evidenciariam mais fortemente no Brasil na década de 1990. No entanto, há um aspecto caro à teoria de González Rey que se apresenta como um elemento que distingue suas contribuições na saúde das pesquisas da Saúde Coletiva, que é a centralidade dos processos subjetivos do sujeito na constituição de um estado de saúde.

Em estudos recentes, González Rey (2011) vem consolidando a teoria da subjetividade como referencial basilar no desenvolvimento teórico frente às práticas médicas no contexto da saúde mental. Nesse sentido, acentua-se sua 
severa crítica à perspectiva causal e determinista das práticas psiquiátricas que compreendem a patologia como uma entidade que reduz o sujeito à condição de vítima de um ente externo a ele, desconsiderando completamente os processos de configuração subjetiva advindos de complexos desdobramentos do modo de vida da pessoa. Para o autor, a perda da condição de sujeito frente à atuação dos médicos tem levado paulatinamente ao reforço de um contexto institucionalizado da terapia no qual o paciente encontra-se sempre numa posição de refém em sua condição incompetente na relação com o médico. Com efeito, González Rey (2011) defende como imprescindivel recuperar os aspectos subjetivos das doenças, articulando de modo contundente as dimensões culturais e sociais da saúde que haviam sido desconsideradas no modelo biomédico caracterizado por sua base epistemológica organicista e atomista. Assim, González Rey (2011) aponta como imprescindível a emergência do sujeito nos processos terapêuticos sem os quais torna-se muito difícil uma mudança qualitativa nas práticas afeitas à saúde mental (COSTA; GOULART, 2015).

De forma propositiva, percebe-se que a emergência do sujeito no contexto da saúde mental alude aos aspectos educativos que podem contribuir significativamente aos quadros de recuperação do transtorno. Essa é uma das hipóteses que Goulart (2013a) levantou no tocante a sua pesquisa que investigou os processos de alta nos Centros de Atenção Psicossocial (CAPS) em Brasília e que tomou como referencial teórico a teoria da subjetividade numa perspectiva cultural-histórica. Ademais, Goulart (2013a) percebeu que as atividades realizadas no CAPS não enfatizavam os objetivos emancipatórios reclamados pelo programa, fato que se apresenta como uma contradição aos anseios da reforma psiquiátrica brasileira. Diante disto, Goulart (2013a, p.30), ao pensar as contribuições da epistemologia qualitativa, argumenta que o

[...] estudo da subjetividade emerge enquanto possibilidade teórica para pesquisas no contexto proposto, ao possibilitar a produção de inteligibilidades relacionadas às formas com que complexos processos humanos no âmbito da saúde mental são vivenciados cotidianamente e que não poderiam ser observados diretamente na cena empírica sem o favorecimento de recursos teóricos. Logicamente, pode-se estudar esses processos a partir de diversos vieses, tais como: a historia, aspectos culturais 
compartilhados e os aspectos biológicos envolvidos. No entanto, pesquisar a subjetividade é precisamente buscar entender como essas mais diversas esferas se integram na vivência da pessoa, em sua produção simbólica e emocional no curso do seu desenvolvimento. Possibilita, nesse sentido, a articulação entre as dimensões da saúde e da educação na vivencia de situações concretas em que essas dimensões estejam intensamente implicadas.

Ao exploramos e, por conseguinte, defendermos a inserção qualitativa da Teoria da Subjetividade de González Rey no campo da educação e saúde ratificamos deliberadamente as bases de uma justificativa de nossas pretensões investigativas em educação física no campo da Saúde Pública e que, nos termos apresentados mais à frente da tese, vinculou-se à educação com vistas a refletir a produção de sentidos subjetivos da atuação dos profissionais de educação física na saúde mental. Nossa filiação a esta perspectiva epistemológica identificou uma promissora possibilidade de alargamentos às pesquisas em educação física a partir desse referencial. Uma vez em que compreendemos a área configurada segundo sua relação orgânica, tanto com a educação como com a saúde, sublinhamos que embora seja um desafio situarmos nosso estudo sobre estes fundamentos, entendemos nossa opção como uma forma latente para se traduzir em ganhos teórico-metodológicos importantes, tanto na esfera da pesquisa como na da intervenção profissional da educação física. Dito isso, passamos na sequência a contextualizar a educação física na saúde. 


\section{EDUCAÇÃO FÍSICA, SUBJETIVIDADE E SAÚDE PÚBLICA}

\section{Breves apontamentos históricos da relação entre a Educação Física e Saúde}

Embora não seja objeto de estudo desta pesquisa, alguns componentes históricos da relação Educação Física e Saúde certamente contribuem a uma aproximação mais refinada do entendimento sobre a inserção da área nesse campo, sobretudo, quando se observa que boa parte dos tensionamentos dessa relação pode ser compreendida a partir de alguns apontamentos historiográficos. Ademais, é fundamental situarmos historicamente nosso tema entendendo que a forma com a qual interpretamos o processo histórico da educação física implica severamente nas considerações.

No Brasil, o nascimento da educação física possui uma herança europeia fortemente acentuada pelo processo de industrialização e urbanização e pela consolidação dos estados nacionais. A Europa do século XIX rapidamente percebeu que a força física de uma nação interfere diretamente em sua prosperidade. Este período, marcadamente de avanço do modo de produção capitalista, requereu um indivíduo cada vez mais forte, sadio e, sobretudo, produtivo. Lado a lado a isso, um Estado que precisava se firmar territorialmente compreendeu que o seu poderio bélico também passava pelo treinamento dos soldados. É sobre esse pano de fundo que a educação física se apresentou como "a própria expressão física da sociedade do capital. Ela encarna e expressa os gestos automatizados, disciplinados, e se faz protagonista de um corpo "saudável"; torna-se receita e remédio para curar os homens de sua letargia, indolência, preguiça, imoralidade, e desse modo, passa a integrar o discurso médico, pedagógico... familiar" (SOARES, 2007, p.6).

A gênese de educação física atrelada ao contexto da emergência do liberalismo europeu - em sua porção ocidental - foi preponderante para uma assimilação brasileira desde uma perspectiva funcionalista de corpo. Isso irá repercutir destacadamente ao longo de toda a trajetória acadêmica e profissional da educação física no Brasil. Tanto o Estado liberal brasileiro como a sua burguesia empreenderão um projeto de poder vinculado a esta perspectiva 
funcionalista de corpo nos mais diversos campos de atuação da área, algo que corrobora a análise de Foucault (1979, p.147):

É preciso afastar uma tese muito difundida, segundo a qual o poder nas sociedades burguesas e capitalistas teria negado a realidade do corpo em proveito da alma, da consciência, da idealidade. Na verdade, nada é mais material, nada é mais físico, mais corporal que o exercício de poder... Qual é o tipo de investimento do corpo que é necessário e suficiente ao funcionamento de uma sociedade capitalista como a nossa? Eu penso que, do século XVII ao início do XX, acreditou-se que o investimento do corpo pelo poder devia ser denso, rígido, constante, meticuloso. Daí esses terríveis regimes disciplinares que se encontram nas escolas, nos hospitais, nas casernas, nas oficinas, nas cidades, nos edifícios, nas famílias... [...]. (grifos nossos) ${ }^{7}$.

A associação da educação física brasileira à Saúde ocorre desde o seu nascimento e acompanha larga proximidade com a instituição médica ${ }^{8}$. Os conhecimentos gestados pela medicina social europeia contribuíram sobejamente para uma nova organização do Estado brasileiro no início do século $X X$, com desdobramentos econômicos, políticos e sociais. Há por meio do movimento médico-higienista uma clara opção do Estado em valorizar politicamente as ações médicas (COSTA, 1983). Tal fato histórico foi decisivo na constituição da educação física no Brasil. A maior expressão da influência médico-higienista na Educação Física brasileira está disposta no discurso do pensamento pedagógico brasileiro da época, mormente em Rui Barbosa e Fernando de Azevedo ${ }^{9}$. Para

\footnotetext{
${ }^{7}$ Motiva-nos sublinharmos tais palavras na medida em que entendemos a Educação Física brasileira como partícipe dos malogros apontados por Foucault.

${ }^{8}$ Outra importante instituição que impacta a constituição histórica da Educação Física é a militar com a importação dos métodos ginásticos europeus no treinamento de soldados. A partir da década de 1960, na sequência do Golpe Militar Burguês, a instituição esportiva também será fundamental para a compreensão histórica dos rumos da Educação Física brasileira. Por uma questão de recorte temático, ficaremos apenas com uma breve análise da aproximação da área com a instituição médica.

${ }^{9}$ Certamente Rui Barbosa e Fernando de Azevedo podem ser compreendidos como dois dos grandes próceres da gênese da Educação Física no Brasil. O primeiro por conta dos pareceres sobre a Reforma de Educação Leôncio de Carvalho, que sugeria pela primeira vez a obrigatoriedade da Educação Física como componente curricular na escola; e o segundo em função de seu tratado teórico intitulado "Da Educação Física" que compõe as bases teóricas de uma concepção fisiologista mas numa perspectiva de intervenção pedagógica.
} 
Soares (2007), o jurista baiano e o sociólogo mineiro privilegiaram em suas propostas uma educação física assentada em base anatomofisiológica com grande potencial para desenvolver o caráter higiênico e eugênico, tão caro ao movimento sanitarista brasileiro iniciado na segunda metade do século XIX.

Esse duplo objetivo - higienizar e eugenizar - guarda relação com as características da elite colonial brasileira, extremamente racista. Essa mesma elite dirigente irá valorizar a Educação Física entendendo que por meio da ginástica era possível empreender um indivíduo "de uma construção anatômica que pudesse representar a classe dominante e a raça branca, atribuindo-lhe superioridade" (SOARES, 2007, p. 72). Na esteira dessas ideias, surgirão algumas publicações que mesmo abordando questões de saúde, em geral, irão paulatinamente conferir certa cientificidade à educação física. Grosso modo, o corolário dessa pretensa cientificização da educação física acompanhou a ideia de ter no exercício físico um aliado para o recrudescimento de uma individualização biológica do corpo e o início de uma subsunção à instituição médica. Senão vejamos:

O exercício físico era, objetivamente, mais um valioso canal para a medicalização da sociedade. Era necessário adequá-lo, discriminá-lo por idade e sexo, atendendo, assim, exclusivamente ao reconhecimento da existência das diferenças biológicas das crianças. Quem detinha o conhecimento sobre estas diferentes capacidades biológicas das crianças, senão os médicos? Ora, se eram os médicos que detinham aquele saber, somente eles poderiam prescrever mais este remédio: o exercício físico, com todas as suas particularidades e para todos os corpos particulares. (SOARES, 2007, p.81).

Dessa forma, estavam lançadas as bases epistemológicas da formação em educação física que, por conseguinte, deveriam impor larga relação com uma concepção biológica e médica de corpo, que por sua vez mantinha-se destituído completamente de historicidade. Os desdobramentos dessa face histórica da educação física empreenderam uma abordagem positivista de ciência na área, que revelou ao longo de todo o século XX e nesse início de século XXI uma subordinação da educação física às ciências biológicas com severos impactos na formação/atuação dos profissionais nos mais diversos campos. 
No que concerne à discussão da Saúde na educação física, a incorporação da veia epistêmica oriunda das ciências biológicas irá contribuir para a assunção da área nesse campo científico. A formação profissional e científica será assim legitimada por meio de sua constituição como subárea das ciências biológicas, como pode se observar no enquadramento da educação física no Conselho Nacional de Desenvolvimento Científico e Tecnológico (CNPq). A partir da década de 1980, os desdobramentos dessa construção de identidade se cercaram de tensionamentos a partir do amadurecimento científico da educação física em compasso com os seus novos diálogos com outras áreas de conhecimento, mormente a das ciências humanas e sociais. Esse é o mote da próxima seção, ao pensar atualmente o debate da educação física na Saúde.

\section{O debate crítico da Educação Física na Saúde}

A partir do processo de redemocratização brasileira na década de 1980, a educação física passou por uma espécie de catarse epistemológica, observando a necessidade de confrontar-se com os rumos históricos vividos no país e no mundo. A recém-saída de um período ditatorial e a retomada dos direitos políticos civis irá se articular ao início de um processo de formação da pós-graduação brasileira em educação física e, embora não de forma hegemônica, o diálogo com as ciências humanas e sociais irá se processar. Anteriormente a este período, as obras acadêmicas que circulavam na educação física, caracterizaram-se principalmente a partir de conteúdos técnico-táticos esportivos em formato de verdadeiros manuais práticos, além de compêndios de fisiologia do exercício e guias de preparação física. $O$ que se seguiu então, foi a paulatina difusão interdisciplinar entendendo que as "ciências historicamente constituídas ofereceriam base teórica para os estudos da educação física, do corpo e dos movimentos humanos, destacando-se dentre estas a psicologia, a história, a sociologia e a pedagogia" (DAOLIO, 1998, p.44). O maior impacto desse movimento científico da área aconteceu no âmbito da Educação Física Escolar e 
do Esporte e se deu, sobretudo, por meio da apropriação da teoria social marxista.

A construção do debate acadêmico-científico crítico da educação física na Saúde tem como pano de fundo esse movimento de aproximação e profícuo diálogo com as ciências sociais e, em parte, com a teoria social. Somam-se a isso os rumos históricos que o Estado brasileiro viveu no âmbito político com o processo de redemocratização, precipuamente com o advento da Constituição Cidadã de 1988 que legitimou um novo processo de política pública e social no campo da Saúde, materializada em 1990 pelo Sistema Único de Saúde (SUS). Além disso, destaca-se o encontro, naquele contexto, com a emergente área da Saúde Coletiva que viabilizou a ampliação de olhares progressistas no interior da educação física e que cada vez mais vêm se desdobrando, embora com alguns limites.

Não obstante o debate da educação física na Saúde, desde uma perspectiva crítica, seja relativamente novo - com pouco mais de vinte anos - é possível realizar um recorte a partir de três apontamentos, num esforço de síntese: a) a ampliação do conceito de saúde que possibilita o desvelamento de como a educação física se apresenta no mundo contemporâneo em uma sociedade do consumo; b) a ascensão de uma falsa consciência de como a educação física se insere no trabalho com a saúde que se desdobra na culpabilização do indivíduo no aparecimento de doenças que poderiam ter sido evitadas pelo exercício físico; c) a necessária construção e reafirmação de uma epistemologia que articule as nuanças imperativas do social em detrimento da tradicional concepção biologicista de corpo na educação física. Trata-se de grandes questões que compreendemos como um possível conjunto temático e genérico do atual debate acadêmico da área. Vale dizer que essa divisão possui função meramente analítica uma vez que, do ponto de vista desta pesquisa, os três assuntos supracitados perfazem uma trama complexa que se integram e se articulam na composição de qualquer debate e de tomada de posição, apresentando dessa forma, características de recursividade entre elas. De todo modo, é possível perceber um pequeno, mas sólido lastro bibliográfico em torno destas questões passíveis de serem aqui minimamente discutidas. 
Como já mencionado anteriormente, o diálogo com a área da Saúde Coletiva certamente foi o "divisor de águas" na produção teórica da educação física em sua relação com o campo da Saúde. De maneira mais pontual, a apropriação do (novo) conceito de Saúde foi o mote principal para essa espécie de "virada teórica" da área. Na medicina não foi diferente; e como a educação física guarda relação histórica com a instituição médica, a ampliação do conceito de saúde irá repercutir na área. Czeresnia (2012) afirma que o conceito de saúde gestado historicamente na medicina e amparado por uma cientificidade, se coloca de forma objetiva segundo o foco exclusivamente da doença, e não da saúde. Assim, na medida em que a medicina compreendia o corpo exclusivamente em sua dimensão biofisiológica, o resultado foi encerrar o conceito de saúde apenas como ausência de doença. Entretanto, há em Canguilhem (1982) contundente salto qualitativo da maneira de se pensar a relação saúde-doença a partir do cotejamento entre o estado patológico do indivíduo e o entendimento da condição de normalidade.

Se reconhecermos que a doença não deixa de ser uma espécie de norma biológica, consequentemente o estado patológico não pode ser chamado de anormal no sentido absoluto, mas anormal apenas na relação com uma situação determinada. Reciprocamente, ser sadio e ser normal não são fatos totalmente equivalentes, já que o patológico é uma espécie de normal. Ser sadio significa não apenas ser normal numa situação determinada, mas ser, também, normativo, nessa situação e em outras situações eventuais. O que caracteriza a saúde é a possibilidade de ultrapassar a norma que define o normal momentâneo, a possibilidade de tolerar infrações à norma habitual e de instituir normas novas em situações novas. (CANGUILHEM, 1982, p. 158).

Se corroborarmos com as ideais de Canguilhem (1982), não será difícil perceber o quão se processa de maneira intensa um movimento de medicalização da sociedade contemporânea, que se materializa na lógica da fabricação da doença quando a indústria farmacêutica se mostra como uma imposição do mercado $^{10}$ (PIGNARRE, 1999).

\footnotetext{
${ }^{10}$ Não há dúvidas que o estabelecimento de um conceito ampliado em saúde sofre pressões advindas do sistema político-econômico vigente no mundo, que faz mitigar os avanços de um conceito mais maduro de saúde. Ora, a indústria farmacêutica é, segundo dados da Organização Mundial do Comércio, a segunda maior do mundo, ficando atrás apenas da indústria de
} 
Grosso modo, a apropriação pela educação física desse veio filosóficocientífico sobre "novas formas de se olhar a saúde" abriu um campo teórico significativo na área desde uma perspectiva crítica. Os desdobramentos históricos da relação da educação física no campo da Saúde haviam gerado uma noção distorcida das potencialidades teórico-metodológicas da área, reduzindo a intervenção profissional à prescrição e acompanhamento do indivíduo durante o exercício físico. Do ponto de vista teórico, o exercício físico era tido como remédio profilático às doenças do corpo. Há, portanto, a objetivação da intervenção profissional da educação física que adveio da herança higiênica e eugênica da relação da área com a instituição médica (como vimos anteriormente) e irá, a partir da década de 1980, transmutar-se em objeto/mercadoria de uma sociedade que vive o pleno desenvolvimento do neoliberalismo no país. Assim, empurrado fortemente pelo discurso midiático, o profissional de educação física logo se estabeleceu como aquele que possui o instrumental perfeito para "fornecer saúde" à população, bastando aos sujeitos quererem, na verdade, pagarem. Nesse sentido, os trabalhos de Carvalho (2004) e Palma $(2000,2001)$ permitem esclarecer esse processo extremamente atual e que ascende uma falsa consciência das pessoas sobre o trabalho do profissional de educação física no Brasil. Destacam-se as características denuncistas de uma educação física "para poucos".

A noção de benesses do exercício físico está acentuadamente marcada pelo senso comum forjado na mídia. São inúmeras as revistas e notícias que os meios de comunicação vinculam sobre a ideia de que o exercício físico "em si" traz saúde. Tal ideia carece de adensamento teórico-científico. (CARVALHO, 2004). Palma et. al. (2003) preferem problematizar se de fato é o exercício físico que promove um indivíduo saudável ou se é o indivíduo saudável que pode procurar em seu lazer uma rotina de realização do exercício físico? Nesse estudo, em específico, os autores concluem que a adesão à prática de exercício se relaciona com as características socioeconômicas do público que frequenta as academias de ginástica, as quais se situam numa camada social privilegiada.

armamentos. Nesse sentido, não seria exagero afirmar que o aumento de uma cultura da doença é muito mais lucrativo e retroalimenta o sistema global capitalista no mundo. 
Assevera-se, portanto, a necessidade de alargamento do entendimento de como se dá a efetividade do exercício físico como prática regular na rotina das pessoas. Nesse sentido, podemos inferir que a visão biologicista-acadêmica de corpo - hegemonicamente constituída no interior da educação física - nega a historicidade do sujeito quando propõe investigações descontextualizadas à vida social, supondo encontrar resultados atomísticos em torno dos efeitos do exercício físico na saúde das pessoas.

Acompanha esse debate a crescente massificação do ideal estético de corpo numa sociedade de consumo. É nesse contexto que se potencializa a forma mercantilista com qual a intervenção da educação física se projeta na sua, nesse caso, pseudo-relação com a saúde. Há, portanto, um movimento "de massificação de uma norma moralizante de aparência física utópica de 'corpo sarado', da 'geração saúde' e do 'estilo de vida ativo', que estão em curso na sociedade contemporânea" (BAGRICHEVSKY, ESTEVÃO, 2005, p.6). Algumas iniciativas, tanto do Estado como da iniciativa privada, são reveladoras de como se aceita acriticamente a ideia de que se manter ativo é suficiente para obter saúde, desprezando-se completamente o panorama socioeconômico da maioria dos brasileiros e sua realidade de pobreza generalizada. Ademais, a atomização dos efeitos benéficos do exercício físico promove uma dinâmica de culpabilização do sujeito que, ao se aceitar sedentário, demarca sua pré-condição de doente. Mais uma vez, revela-se a herança anacrônica da compreensão biologicista de saúde da educação física associada ao reducionismo da não contemplação de aspectos sociais, culturais, econômicos e históricos na constituição de um estado de saúde para o sujeito. Palma (2000, p.97) explica que "se o processo saúde-doença fosse uma determinação biológica, caberia ao indivíduo alterar seus hábitos de saúde e estilos de vida para encerrar a causa e, assim, cessar o efeito". "A atividade física, ao tempo que canaliza a atenção da sociedade para as suas capacidades de delinear corpos saudáveis, fortes e belos, mascara outros determinantes do setor e do quadro social brasileiro. De outra forma, se superestima o papel determinante da atividade física em relação à saúde" (CARVALHO, 2004, p.87). Para Carvalho (2004), todo esse discurso que coloca o exercício físico como fator preponderante na conquista de saúde imputa ao indivíduo a inteira 
responsabilidade de ao se manter ativo, remediar os problemas da saúde, sacando do Estado o dever de trabalhar pela produção das condições sociais, econômicas e culturais que possibilitariam a maioria das pessoas realizar exercício físico. Fica claro, portanto, que para o pensamento crítico da Educação Física na saúde, a prática de exercício pela população não é uma questão de escolha, mas sim, de oportunidade.

Esse debate se liga ao processo de busca por um amadurecimento científico da área a partir de uma inflexão epistemológica, que sugere o abandono ou arrefecimento da tradição dos parâmetros biológicos de produção do conhecimento em prol de se pensar ampliado e criticamente a relação da educação física com a saúde segundo a orientação das ciências sociais. Naturalmente ao se enfatizar essa tese, a educação física declara-se preocupada com o desenvolvimento de sua inserção nos espaços políticos da saúde pública e, nesse movimento, os determinismos biológicos precisam ser superados. Nos dizeres de Palma (2001, p.24):

Tratar da saúde é, em última instância, compreender as tramas sociais que se desenrolam nos projetos e políticas públicas. Parece ingênuo aceitar o determinante biológico, como razão única, para conferir as análises sobre o processo saúde-doença. O adoecer humano não deve ser tratado somente sob a forma de uma relação biológica de causa e efeito, tão simples, que desconsidere outros aspectos relevantes, tais como os contextos socioeconômicos e históricos.

Fica evidente que a associação da educação física à Saúde nos termos observado em Palma (2001) vislumbram um desejo de empregar esforços epistemológicos apartado dos cânones das ciências biológicas. Além disso, a defesa de que ao se "tratar da saúde" deve-se fomentar projetos e políticas públicas, o autor revela suas aspirações por uma ciência engajada socialmente. Assim, ao pautar a epistemologia da educação física na saúde, um caminho parece certo, que é o de sua articulação à saúde coletiva. 
A dificuldade de comunicarmo-nos com outras áreas da saúde pode ser em virtude da "imagem" que ainda muito têm das ciências médicas, associando-as às técnicas medicamentosas, cirúrgicas e eletrônicas que interferem no corpo biológico e na manifestação e enfrentamento da doença como processo isolado da vida, do cotidiano das pessoas. Nesse sentido, a saúde coletiva rompe com esse modelo. Ela chama a atenção para a necessidade, por exemplo, de fazer-se pesquisa voltada para a atenção primária, direcionada ao serviço básico de atendimento à população e para a educação em saúde, não só para a pessoa, mas também para a comunidade, para a família, na direção da população, das políticas sociais e das políticas públicas. (CARVALHO, 2006, p. 162).

O debate epistemológico da educação física que propõem o biológico e o social em oposição reside historicamente no contexto político da década de 1980 e que aqui já foi mencionado. A questão é que a educação física pautou essa discussão na ordem de "ser ou não ser ciência" (BRACHT, 2007) e uma das soluções encontradas pela comunidade científica da área para encontrar legitimidade ao se situar no campo científico foi de se atrelar ao campo da saúde. Como o campo da saúde, do ponto de vista hegemônico é determinado pelas pesquisas biomédicas, a educação física incorporou os cânones da produção de conhecimento desse campo, aos quais sobejam as características disciplinares, atomísticas, positivistas e reducionistas (CARVALHO, 2005). Não obstante haja um salto qualitativo das pesquisas em educação física que ao atravessarem à Saúde o fazem por meio da saúde coletiva, é sabido que "os saberes e as práticas em saúde que prevalecem na Educação Física são ainda os que se fixam em dados estatísticos, que reduzem o processo saúde-doença a uma relação causal determinada biologicamente [...]" (CARVALHO, 2005, p.102).

O debate hodierno da educação física na saúde (pública), aponta em direção do movimento crítico em saúde de uma parte da comunidade acadêmica da educação física que, paulatinamente, tem procurado modificar essa conjuntura que fora apontada em Carvalho (2005). Obviamente isso ocorre a partir do trabalho de um conjunto de pesquisadores que possuem a mesma concepção de saúde da autora supracitada. Nesse sentido, percebe-se um salto qualitativo das mais recentes publicações e de como a aproximação com a saúde coletiva passou a ser vocalizada na educação física de maneira a se abordar novos temas 
que, ao mesmo tempo, continuam a defender a saúde como direito social, mas que também agora, colocam como desafio teórico a legitimação qualificada (e crítica) da intervenção do profissional de educação física no espaço da saúde pública. Isso pode ser constatado nos estudos de Wachs e Fraga (2009) e Abib et. al.(2010) no âmbito da saúde mental e em Moretti et. al. (2009) na experiência com práticas corporais alternativas na atenção primária. Em Fraga et. al (2013), materializa-se mais uma importante contribuição em torno da aproximação da educação física com a Saúde Coletiva. Esta obra é fruto de um seminário que promoveu debates tomando como mote a educação física em interface com a saúde pública a partir de referências das ciências humanas e sociais. Três grupos de pesquisa ${ }^{(11)}$ promovem uma investigação conjunta que resultará no futuro em outros produtos, tendo como propósito acompanhar e analisar os processos de composição e articulação entre ensino, serviço e comunidade com vistas a constituir uma rede de saberes e práticas que respondam aos desafios da formação em saúde comprometida com a defesa e consolidação do SUS. Esses são alguns exemplos dos expressivos avanços do campo teórico da educação física na saúde pública.

Não obstante a isso, tais avanços não ocorrem sem tensionamentos. Mesmo agora, ao passo em que se debate o direito à saúde integrada a uma política de promoção da saúde, a educação física, incorporada à lei, o faz em meio a interesses e disputas políticas.

Nesse sentido, o recente ensaio de Damico e Knuth (2014) inaugura uma discussão que pode demonstrar certo amadurecimento teórico da área delineada no campo da saúde e que se processa como a repercussão do tensionamento entre o biológico e o social no âmbito das políticas públicas de saúde que paulatinamente vêm absorvendo o trabalho do profissional de educação física. Damico e Knuth (2014) tomam a Política Nacional de Promoção da Saúde, efetivada em 2006, como pano de fundo de uma discussão que encerra nos

\footnotetext{
${ }^{11}$ Alguns grupos de pesquisa no Brasil tendem a um protagonismo. Vinculados à pós-graduação, é o caso de 'Educação Física \& Saúde Coletiva \& Filosofia' sediado na USP, o 'Políticas de Formação em Educação Física e Saúde' (POLIFES) com sede na UFRGS e o 'Laboratório de Estudos em Educação Física' (LESEF) presente na UFES.
} 
conceitos de 'atividade física' e 'práticas corporais' os sentidos de poder duais extraídos do histórico e tenso debate entre o biológico e o social na educação física. Quando o documento da política institucional inscreve os conceitos na forma de 'práticas corporais/atividade física' o faz com alguns interesses que certamente precisam ser analisados. Atualmente há em curso na educação física uma disputa política que abarca os conceitos de 'atividade física' e 'práticas corporais $^{12}$ em oposição, mas que se sentem "interpeladas e convocadas a propor o melhor modelo de sedução e convencimento para integrar as pessoas às normas culturais difundidas pelo discurso da promoção da saúde" (DAMICO \& KNUTH, 2014, p.334). Vale dizer que tais conceitos se posicionam de maneira diametralmente opostos quando se observa aspectos em torno da concepção epistemológica e compreensão teleológica da intervenção profissional da Educação Física na saúde pública.

Visto isso, uma última análise aqui é necessária. A interlocução da educação física com a Saúde Coletiva a conduz também a absorver, em parte, os seus dilemas e conflitos. Assim, não seria de todo equivocado refletir que ao se adentrar no debate da política de promoção da saúde, a educação física carrega a polarização do debate que na Saúde Coletiva se apresenta como a perspectiva regulatória versus a perspectiva emancipatória (BUSS, 2005; HEIDMANN et.al., 2006) sendo a primeira aquela que foca os hábitos de vida e o estilo de vida dos indivíduos como condicionante à saúde e o culpabiliza pela sua perda; e a segunda, aquela que compreende que os determinantes sociais da saúde devem ser levadas à cabo por uma política que desenvolva ações intersetoriais observando a necessidade de contemplar o conceito ampliado de saúde (SILVA, BAPTISTA, 2014).

Ao se observar a produção teórica em educação física na saúde, convém destacar que os conceitos 'atividade física' e 'práticas corporais' agregam, grosso modo, elementos teóricos que as fazem representantes da educação física nesse debate da Saúde Coletiva. Sendo o primeiro, representante a partir de uma

\footnotetext{
${ }^{12}$ Por estar fora do escopo dessa seção, não avançamos na diferenciação desses dois conceitos. Entretanto, optamos pelo conceito de práticas corporais como referencial teórico da pesquisa no que tange a discussão oriunda da pesquisa de campo realizada e apresentada mais à frente.
} 
perspectiva regulatória, e o segundo, representante que segue uma perspectiva emancipatória. A visão de antagonismo dessas categorias e como elas se processam na produção de conhecimento em educação física são reveladoras de uma tensão que determinam sua ação política e, sobretudo, a formação profissional.

\section{Reflexões em perspectiva para projetar a Educação Física na Teoria da Subjetividade}

A educação física brasileira do tempo presente parece viver uma nova crise. A década de 1980 foi catalisadora de sua primeira crise (MEDINA, 1983) e teve como principal desdobramento a incorporação da teoria social como agente científico norteador ou, ao menos, tensionador de sua prática social principalmente nos espaços da escola, do esporte e da saúde. À época fora um debate imprescindível aos objetivos identitários da área. Passados pouco mais de trinta anos, em nossa opinião, a educação física passa a reviver outra crise, entretanto, pressionada por um contexto histórico bastante distinto. O eminente fim do socialismo real consubstanciado na mais forte crise do capitalismo, une-se aos tempos de uma sociedade que chegou a níveis de consumo que tem degradado o planeta a tal ponto de ser possível vaticinar o fim da humanidade. Obviamente que esse panorama mundial interfere nas formas de se pensar a humanidade e a ciência, representante legitimadora desse pensamento, tem requerido novos modelos teóricos que busquem não só respostas explicativas para o vivido, mas que também proponham solução para os problemas enfrentados. Nesse sentido e retornando ao debate específico da crise identitária da educação física, entendemos como fundamental enriquecer o debate epistemológico da área introduzindo novos aportes científicos que paulatinamente vem se constituindo num movimento pós-estruturalista da área. Isso já é possível perceber no interior do debate acadêmico da educação física em trabalhos como o de Bracht e Almeida (2006) e Fensterseifer (2001). Ao contrário da "primeira crise" da educação física que subsidiou seus apontamentos segundo os princípios 
da modernidade, tendo no materialismo-histórico sua maior expressão epistemológica, esses autores têm paulatinamente reivindicado novos olhares para a especificidade da educação física nos termos de outro paradigma.

Na esteira desse movimento é que apresentamos nosso estudo no âmbito da Teoria da Subjetividade numa perspectiva cultural-histórica. Embora possua algumas particularidades, é certo que ela potencializa uma inovação epistêmica da educação física com possibilidades reais de impactar a esfera profissional. Neste primeiro trabalho se apresenta no campo da saúde, mas, por meio da Epistemologia Qualitativa (GONZÁLEZ REY, 1997, 2005d) possui bases teóricometodológicas capazes de produzir investigações em todas as práticas sociais da área.

Nossa inspiração está atrelada a algumas inquietações não resolvidas pela teoria social, sobretudo àquelas que segundo nosso entendimento, distorce o que de mais importante há em Marx que é a dialética como forma ontológica de compreensão da realidade. Nesse sentido concordamos com Berger e Luckmann (2011, p.16-17):

A sociologia do conhecimento tem sua raiz na proposição de Marx que declara ser a consciência do homem determinada por seu ser social. Sem dúvida tem havido muitos debates para se saber ao certo que espécie de determinação Marx tinha em mente. Pode-se dizer, com certeza, que muito da grande "luta com Marx" [...] foi realmente uma luta contra a defeituosa interpretação de Marx pelos marxistas modernos.

A sociologia do conhecimento foi particularmente fascinada pelos dois conceitos gêmeos, estabelecidos por Marx, de "infraestrutura" e "superestrutura" (Unterbau, Ueberbau). Foi neste ponto principalmente que a controvérsia se tornou violenta a respeito da correta interpretação do próprio pensamento de Marx. O marxismo posterior teve a tendência de identificar a "infraestrutura" com a estrutura econômica tout court, da qual se supunha que a "superestrutura" era um "reflexo" direto (assim, por exemplo, Lenin). É agora de todo de claro que isto representa incorretamente $\mathrm{O}$ pensamento de Marx, pois $\mathrm{O}$ caráter essencialmente mecanicista, em vez de dialético, desta espécie de determinismo econômico torna-o suspeito. O que interessava a Marx é que o pensamento humano funda-se na atividade humana 
("trabalho" no sentido mais amplo da palavra) e nas relações sociais produzidas por esta atividade.

Em nosso ponto de vista, o trecho final da argumentação de Berger e Luckmann (2011) sinaliza, grosso modo, os limites ${ }^{13}$ de Marx em face à compreensão dos desdobramentos das relações sociais produzidas pelo trabalho que vão resultar na ideia de uma sociedade como produto humano e, por sua vez, consignada a ser uma realidade objetiva. Eivado das contribuições de Marx, Vygotsky pôde ascender uma teoria enriquecida dos processos psicológicos e que deu pistas da necessária incorporação dos processos de subjetivação para compreensão da realidade. Isso se deu numa terceira fase do pensamento vygotskyano (GONZÁLEZ REY, 2012b) ${ }^{14}$ e que o autor não desenvolveu devido à precocidade de sua vida. Assim, são ofertadas pistas que integradas ao paradigma da complexidade de Morin (2006) oferecem elementos teóricos importantes para se entender uma realidade que se constitui não por sua objetividade, mas pela sua subjetividade.

O pensamento complexo derivado de Morin (2006) se posiciona como um paradigma que pretende superar a lógica cartesiana, encaminhando a compreensão da realidade a partir do pensamento sistêmico e ecológico e que procura religar os saberes fragmentados pela modernidade em sua pretensão cientificista; também problematiza e contextualiza historicamente aquilo que parece disperso, concebe o sujeito como produto e produtor de cultura e de si mesmo de forma recursiva e não linear nem mecânica. Logo, a compreensão

\footnotetext{
${ }^{13}$ Não há aqui qualquer pretensão em absolutizar nossas "verdades" ou mesmo caracterizar nossas ideias de forma prepotente. Entendemos o pensamento de Marx uma excelente contribuição filosófica e sociológica do pensamento moderno. Todavia, é mister contextualizar Marx em seu objeto de estudo: as relações sociais no modo de produção capitalista. Para nós, o legado de Marx é ontológico. No âmbito epistemológico, se por um lado Marx é indispensável aos estudos antropossociais, por outro seria um risco entendê-lo como suficiente.

${ }^{14}$ Entendemos que o pensamento de Vygotsky e de qualquer outro pensador não se enquadra num bloco monolítico. Mesmo em Marx é possível perceber uma trajetória complexa de seu pensamento histórico, que indica fases do "jovem" Marx e do "velho" Marx. Isso não quer dizer que não haja uma organicidade na trajetória de seu pensamento, porém, demonstra que o pensamento também "se move" e possui historicidade.
} 
apresentada em Berger e Luckmann (2011) na sociologia foi válida como alerta de que a realidade possui uma dimensão subjetiva, mas que fugia aos autores aquilo que constitui o núcleo gerador de subjetividade, que é a produção de sentidos subjetivos dos sujeitos, revelada na obra de González Rey (1997, 2005a) pensada a partir dos clássicos da psicologia soviética.

Entendemos como válido realizar este excurso reflexivo como aspecto introdutório importante de uma das teses que ansiamos desenvolver neste trabalho: de que os estudos da educação física na saúde não reconhecem a subjetividade como um núcleo fundamental das investigações de suas práticas sociais.

A forma com que o debate acadêmico da educação física na saúde pública está colocado - como pôde ser visto na seção anterior - apresenta-se tensionado pela dicotomia do social e do biológico. Mesmo compreendendo que há um salto qualitativo relevante da educação física quando esta se aproxima aos constructos teóricos da Saúde Coletiva, entendemos que o desenvolvimento teórico da área ganharia um importante reforço caso as pesquisas incorporassem o viés da subjetividade como um enfoque teórico-epistemológico integrador da complexidade humana.

Até aqui, a discussão progressista da educação física na saúde reclama à teoria social seus subsídios epistemológicos, não estendendo às investigações outros aportes que certamente contribuiriam nos rumos que a saúde pública brasileira tem requerido. Esse movimento em prol do recrudescimento do social em detrimento ao biológico pode ser cotejado à dinâmica dicotômica do social com o individual na história. Os desdobramentos dessa polarização radical foram as experiências totalitárias do socialismo real e o aprofundamento da degradada sociedade de consumo face à consolidação do neoliberalismo no mundo. Assim, de um lado os estudos da educação física na saúde sofrem em sua hegemonia dos problemas levantados pela permanência do positivismo e do biologicismo como parâmetros de cientificidade. De outro, os estudos que redimensionam a educação física na saúde à luz das ciências antropossociais compreendem a influência do individual como um epifenômeno do social, negando completamente a ideia de ter na subjetividade uma via legítima de produção de conhecimento. 
Ademais, é necessário reconhecer que a educação física permanece optando, do ponto de vista epistemológico, por um critério de pesquisa baseada na dicotomia sujeito-objeto e tendo nos instrumentos técnicos o imperativo dos procedimentos legitimadores da ciência, o que manifesta mais uma vez a total negação da subjetividade nos processos de construção do conhecimento.

Nos termos que propomos a reflexão do referencial teórico desse trabalho é importante dizer que a subjetividade

[...] não substitui os outros sistemas complexos do homem (bioquímico, ecológico, laboral, saúde, etc.) que também encontram, nas diferentes dimensões sociais, um espaço sensível para o seu desenvolvimento, mas transforma-se em um novo nível na análise desses sistemas, os quais, por sua vez, se convertem em um novo sistema que, historicamente, tem sido ignorado em nome do subjetivismo, do mentalismo e do individualismo. (GONAZÁLEZ REY, 2005d, p.14).

Portanto, nuclear a condição de sujeito nas investigações em educação física não é optar por um subjetivismo acrítico. O subjetivismo foi a forma com que a filosofia positivista tentou, ao longo da história ocidental, suprimir a subjetividade do debate epistemológico de uma época, entendendo que o sujeito era capaz por processos intrapsíquicos gerar uma consciência atomista de visão de mundo. Segundo González Rey (2012a), isso não corresponde à subjetividade por não levar em conta a realidade de contexto social que o sujeito se insere. Ao contrário da visão universalista do subjetivismo, a subjetividade se dá na emergência dos processos humanos produzidos pelos sentidos subjetivos caracterizados, simbólico e emocionalmente, em função da experiência vivida na história e na cultura.

Entendemos que o debate da educação física no âmbito da saúde pública não deveria deixar de imiscuir novos aportes científicos, em especial àqueles que dialogam com o pensamento complexo. Inclusive, nossa proposta temática de pesquisa procurou se apropriar da discussão da reforma psiquiátrica brasileira por perceber nela elementos que aproximam e requerem um olhar epistêmico distinto 
daqueles que já estão dados. Paulo Amarante, importante pesquisador da discussão da saúde mental no Brasil tem reclamado isso, senão vejamos:

Umberto Maturana, Ilya Prigogine, Isabele Stengers, Edgar Morin, Henri Atlan, para citar apenas alguns poucos, são exemplos de autores que, com frequência, nos auxiliam nas reflexões sobre a Reforma Psiquiátrica, no desafio presente e fundamental de recolocar a dimensão das relações entre conhecimento e objeto. Daí advém um outro conceito fundamental neste processo tem sido o de complexidade. Por exemplo, se adotamos a noção de complexidade para lidar com o conceito de doença, esta deixa de ser um objeto naturalizado, reduzido a uma alteração biológica ou de outra ordem simples, para tornar-se um processo saúde/enfermidade. (AMARANTE, 2009, sn - grifo do autor).

As pesquisas orientadas para a investigação da inserção da educação física na saúde mental, especificamente às que tematizam a reforma psiquiátrica brasileira, são raras. Os CAPS, que se constituem como a materialização da reforma no Brasil, foram objeto de estudo de maneira pioneira na educação física na pesquisa realizada por Wachs e Fraga (2009). É interessante a conclusão dos autores da necessidade da educação física se consolidar no espaço do CAPS em acordo aos princípios reformuladores dos processos de cuidado aos sujeitos com transtorno psíquicos. De todo modo, a exiguidade de estudos da educação física em torno da saúde mental e em especial nos CAPS, justificam novas iniciativas. Nossa intenção foi a de percorrer esse caminho, porém, através do referencial teórico da subjetividade numa perspectiva cultural-histórica. De antemão, entendemos que o sujeito da saúde, ou no caso, o usuário do CAPS e também os profissionais que lá estão, devem se apresentar como sujeitos no curso da investigação. Em nossa opção teórica, devemos entendê-los como sujeitos que se apresentam conscientes de si e do espaço social em que estão inseridos. A aproximação teórica aos aspectos relacionados à temática da saúde mental bem como a incipiente produção acadêmica da educação física neste tema é o assunto do próximo capítulo deste trabalho. 


\section{SAÚDE MENTAL, EDUCAÇÃO E EDUCAÇÃO FÍSICA}

\section{Epistemologia e intervenção profissional na saúde mental: aspectos históricos da reforma psiquiátrica brasileira e o campo da educação como perspectiva}

A loucura, objeto dos meus estudos, era até agora uma ilha perdida no oceano da razão; começo a suspeitar que é um continente.

Simão Bacamarte ${ }^{15}$

O propósito deste momento teórico da fundamentação é o de deslocar a atenção às questões relacionadas às problemáticas apresentadas especificamente no campo da saúde mental. De forma mais pontual, abordaremos duas dimensões importante sobre o debate acadêmico atual da saúde mental ${ }^{16}$, qual seja a dimensão epistemológica e a dimensão da intervenção profissional. Nesse sentido, é importante ressaltar o quão elas necessitam se integrar a fim de responder as demandas que emergem no contexto da reforma psiquiátrica. Com efeito, à guisa de esclarecimento e contextualização da presente temática desta seção, recuperamos alguns apontamentos históricos bem como as bases filosóficas da reforma psiquiátrica e sua constituição em solo brasileiro. Em meio a este debate, produzido em formato de revisão da literatura, discutimos a hipótese de que uma parte significativa das problemáticas apresentadas na constituição da reforma psiquiátrica sugerem a necessidade do atravessamento interdisciplinar com o campo da educação.

A constituição da reforma psiquiátrica brasileira procede a uma crise no âmbito da psiquiatria médica institucional no mundo em meados do século $X X$. Em Birman e Costa (1994) encontramos a defesa de que, à época, o projeto terapêutico no seio da psiquiatria clássica sofrera uma severa inflexão, tanto do ponto de vista teórico como prático em função da mudança de seu objeto. $A$ doença mental que funda o saber e a prática da psiquiatria é substituída - por

\footnotetext{
${ }^{15}$ Personagem protagonista em 'O Alienista', de Machado de Assis.

${ }^{16}$ Vale dizer que o recorte nesta discussão está circunscrito à contribuição da perspectiva da saúde coletiva no que se refere à fundamentação teórica e os estudos aqui abordados.
} 
meio de vários movimentos reformistas na Europa e Estados Unidos - pela perspectiva da promoção da saúde para os indivíduos com transtornos psíquicos.

Antes, a loucura fora sempre um estado patológico, de demência cronificada ou mesmo, em tempos ainda mais remotos, da perturbação do espírito (BIRMAN; COSTA, 1994). Em comum na história está a opção pelo enclausuramento como forma de "tratamento" dos indivíduos acometidos pela desrazão. De diferente, havia a justificativa para o isolamento, enquanto na Idade Média, a saída do louco da cena social tinha como objetivo a proteção - do indivíduo e da sociedade - para um tempo de catarse necessária à purificação do espírito. Na Modernidade, ganha força a pretensão do domínio (científico) do estado da loucura, somente possível quando o objeto está "à mão" dos cientistas e "disposto" a se sujeitar ao caminho que o leve "à cura". Com efeito, está na Modernidade os dispositivos para a emergência do conceito de doença mental. Isso se deveu em grande medida à institucionalização da lógica hospitalocêntrica e ao avanço científico que orientou a formação médica e legitimou o médico como sujeito social detentor das capacidades necessárias para identificar a doença. Em Foucault (1979, p.127, grifo nosso) encontramos a expressão dessa mentalidade (médica) que procurava tender para uma cientificidade da loucura:

\begin{abstract}
Sabemos sobre a sua doença e sua singularidade coisas suficientes, das quais você nem sequer desconfia, para reconhecer que se trata de uma doença; mas desta doença conhecemos o bastante para saber que você não pode exercer sobre ela e em relação a ela nenhum direito. Sua loucura, nossa ciência permite que a chamemos doença e daí em adiante, nós médicos estamos qualificados para intervir e diagnosticar uma loucura que lhe impede de ser um doente como os outros: você será então um doente mental.
\end{abstract}

A partir dessa compreensão, o hospital psiquiátrico passou a ser o lugar representativo da loucura como objeto de estudo, fato que empoderou o médico alienista como sujeito capaz de identificar a doença mental. Ali situava-se o laboratório e a clínica ao mesmo tempo e no mesmo espaço. Vale lembrar, como fez Foucault (2008), que o hospital não nasceu como uma instituição médica. 
Tratava-se, antes do século XVIII, de uma casa de caridade, de filantropia e hospedaria para quem precisasse de cuidados, geralmente mantida por uma ordem cristã. Entretanto, o corolário do ambiente do manicômio, no qual havia se instituído a clausura como forma única de terapia, reservou à história uma trajetória de barbárie e desrespeito ao humano. O desejo de apreensão da loucura pela ciência moderna pressupunha que o processo singular da desrazão era passível de se sujeitar às taxonomias das doenças e as variantes terapêuticas de base científica. Tutelar o louco se tornou o pilar das práticas manicomiais, fato que resultou em histórias de sofrimento, segregação e morte (CASTEL, 1978). No fundo, o sofrimento era asseverado pelas práticas psiquiátricas tendo respaldo na ciência. Era comum a prática de lobotomia, eletrochoque e o coma de insulina, aos quais produziam um estado de letargia, demência e apatia absoluta nos indivíduos sujeitados a estas práticas "médicas".

Além desse contexto de sofrimento, os sujeitos acometidos de uma doença mental, eram "[...] despojados de seus direitos jurídicos, políticos e civis, tornando-se, dessa maneira, um não-cidadão" (AMARANTE, 1996, p.17). A ciência médica legou ao louco a doença mental e reservou a ele o lugar apropriado à terapia, no caso, o manicômio, legitimando dessa forma a condição marginal desse sujeito que representava um perigo à sociedade e à noção de ordem requerida. Durante muito tempo o hospício serviu, em parte, para um processo de higienização social. No Brasil isso não foi diferente, como é relatado no livro de Daniela Arbex, intitulado "Holocausto Brasileiro". Arbex (2013) não escreveu uma obra científico-acadêmica. Trata-se de um livro-reportagem que revelou o lado obscuro das instituições psiquiátricas brasileiras, mais especificamente o caso do Hospital Colônia de Barbacena, em Minas Gerais. O trabalho da jornalista fortalece a tese de como a doença mental e os hospícios serviam como pretexto para uma verdadeira "limpeza social", uma vez que se constatou que $70 \%$ dos internados em Barbacena nem mesmo tinham diagnóstico de doença mental. Ali residiam em sua maioria - em condições extremamente precárias - "[...] epiléticos, alcoolistas, homossexuais, prostitutas, pessoas que se rebelavam ou que se tornaram incômodas para alguém com mais poder" (ARBEX, 2013, p. 14). O caso registrado por Arbex é a ratificação da "instituição total" de 
Goffman (1974) no que corresponde à perpetuação coercitiva da ação de determinadas instituições na vida dos indivíduos, sobretudo o de hospitais psiquiátricos e que geram a completa "mortificação do eu".

O Colônia é só um exemplo de como o modelo manicomial havia fracassado e representava os malogros de uma sociedade que fazia repercutir nas instituições psiquiátricas sua completa negligência às questões de direitos humanos. No âmbito da psiquiatria, tais experiências desumanizadoras demonstrava o quão deveria ser questionado as práticas e saberes psiquiátricos.

Do ponto de vista histórico, o pós-guerra marcou um conjunto de reformas vividas em instituições psiquiátricas na França, Inglaterra, Itália e Estados Unidos que foram balizadoras para a gênese de transformações importantes nas formas de saber, nos discursos e nas práticas psiquiátricas (AMARANTE, 1995). Várias foram as experiências que procuravam transformar o modelo de assistência psiquiátrica, os quais é possível citar as comunidades terapêuticas, de psicoterapia institucional, de psiquiatria de setor, de psiquiatria preventiva e comunitária, de antipsiquiatria, de psiquiatria democrática, estas compreendidas com as mais importantes nesse movimento reformista no mundo (AMARANTE, 1994). No Brasil, entretanto, ao mesmo tempo em que estas experiências se revelavam, também se permaneciam marginais, fruto de ações isoladas completamente desprezadas pelo investimento público. Se asseverava a lógica do modelo asilar de tratamento que paulatinamente incorporava a gestão privada como uma tendência do trabalho referente à psiquiatria. O Brasil além de ir na contramão das reformas que procuravam tensionar o modelo hegemônico da psiquiatria, agora a legitimava como um objeto mercantil. Sobre esse processo de privatização da psiquiatria, escreveu Amarante (1994, p. 79):

$\mathrm{Na}$ década de 60, com a unificação dos institutos de aposentadorias e pensões, é criado o Instituto Nacional de Previdência Social (INPS). O Estado passa a comprar serviços psiquiátricos do setor privado e, ao ser privatizada grande parte da economia, o Estado concilia no setor saúde pressões sociais com o interesse de lucro por parte dos empresários. A doença mental torna-se, definitivamente, um objeto de lucro, uma mercadoria. Ocorre, assim, um enorme aumento do número de vagas e de 
internações em hospitais psiquiátricos privados, principalmente nos grandes centros urbanos. Chega-se ao ponto de a Previdência Social destinar $97 \%$ do total dos recursos da saúde mental para as internações na rede hospitalar.

Grosso modo, esse panorama histórico, revelava por um lado a falência do modelo manicomial em relação às novas práticas psiquiátricas e, por outro lado o desgaste econômico em face às opções políticas que oneravam o Estado brasileiro. Tais aspectos gestavam a época o descontentamento de quem trabalhava na vanguarda desse setor da saúde. A aproximação do processo de redemocratização brasileira - que naquele momento vivia ainda um regime ditatorial - também deve ser considerada no âmbito da organização de um movimento político que pretendia contribuir para transformar as bases da política direcionada ao subsetor saúde mental. Esse movimento ficou conhecido como o da reforma psiquiátrica brasileira, no qual destacamos o Movimento dos Trabalhadores de Saúde Mental (MTSM) e os Núcleos Estaduais de Saúde Mental do Centro Brasileiro de Estudos de Saúde (CEBES). Esses atores sociais e políticos representavam a voz crítica da saúde mental no interior da reforma sanitária brasileira que se processou no final da década de 1970 e culminou na formulação do Sistema Único de Saúde (SUS) disposto na constituição democrática de 1988 e implementada em 1990 (CAMPOS, 1991; PAIM, 2009). Por meio deles surgiram as propostas de reforma de todo o sistema psiquiátrico brasileiro bem como o recrudescimento do debate sobre os saberes e as práticas médicas psiquiátricas. A crítica se deslocava do abandono da pretensão de cura do doente mental por meio do tratamento asilar para uma ampla defesa sobre a necessidade de promover a saúde mental e viver as experiências de assistência colaborativa entre agentes de saúde pública, família e, sobretudo, o sujeito acometido por algum transtorno psíquico.

Essa inflexão nos rumos do modelo de assistência é seguramente um momento de forte influência advindas das ideias de Franco Basaglia e da experiência italiana de romper radicalmente com o paradigma hegemônico da clausura, fato que determinou o fim dos manicômios naquele país. Soma-se à lógica da desinstitucionalização norte-americana, outro aspecto que em grande 
medida contribuiu para o fortalecimento dos argumentos a favor da reforma psiquiátrica brasileira. Ao fim e ao cabo, o debate brasileiro aconteceu por meio de vários eventos de natureza científica e outros organizados por uma base popular que repercutiram diretamente nos rumos das políticas públicas orientadas à saúde mental. Ademais, sua repercussão também incidiu diretamente nos saberes e práticas psiquiátricas, orientando novas possibilidades, do ponto de vista epistemológico e interventivo. A título de registro, tais aspectos são desdobramentos que se deram principalmente da $1^{\text {a }}$ Conferência Nacional de Saúde Mental, realizada em 1987 e do $2^{\circ}$ Encontro Nacional de Trabalhadores da Saúde Mental realizado no mesmo ano e que resultou na Carta de Bauru, documento basilar para o início do movimento de luta antimanicomial no país sob - lema "Por uma sociedade sem manicômios". (AMARANTE,1995, 1996; LOBOSQUE, 2003; TENÓRIO, 2002).

Assim, a mobilização de parte da sociedade civil mais vinculada ao meio acadêmico progressista, aos trabalhadores e servidores públicos da saúde mental e outros grupos representativos de modelos alternativos de assistência psiquiátrica, foi fundamental para assegurar a tramitação de projeto de lei de $\mathrm{n}^{\circ}$ 3.657/89, apresentado pelo deputado federal Paulo Delgado. Nele se instituía um conjunto de ações que procuravam dissolver de maneira progressiva os hospitais e clínicas psiquiátricas no país. Passaram-se pouco mais de dez anos até que, em meio a continuidade do movimento de luta pelo fim dos manicômios, o projeto foi aprovado e sancionado em 2001 sob a Lei de $n^{\circ}$ 10.216. Nascia assim os Centros de Atenção Psicossocial (CAPS) ${ }^{17}$, modelo de assistência alternativo as práticas hospitalocêntricas que tendiam agora a uma prática centrada na gestão de terapias constituídas por uma equipe multiprofissional e que tinham como objetivo a manutenção do sujeito com transtorno psíquico (chamado agora usuário) na comunidade. Na verdade, a lei ia muito além da constituição dos CAPS. Nela, procurava-se ampliar as possibilidades de assistência do setor público a partir de uma regulação mais flexível na articulação com outros setores

\footnotetext{
17 Junto aos CAPS também foram criados os Núcleos de Atenção Psicossosial (NAPS). Por entendermos estes como sinônimos de CAPS, como também entende Amarante (1995), omitimos seu registro no corpo do texto.
} 
da sociedade. A propósito disso, observa-se a criação de leitos psiquiátricos em hospitais gerais, centros de convivência cultural e educativa, grupos de trabalho e ofício cooperativo, residências terapêuticas, etc. Tratavam-se, assim, de experiências diversas que se ocupavam em criar novas formas de serviços terapêuticos no qual o objetivo era reafirmar práticas psicossociais longe da lógica asilar e de segregação.

De todo modo, o CAPS representa a frente vanguardista do novo modelo de assistência para a saúde mental no Brasil. Nesse sentido, não é possível colocá-lo em suspensão no tocante ao nosso objetivo de refletir e discorrer sobre saúde mental. A constituição do CAPS nos desafia a pensar o novo e a dar respostas à desconfiança gerada no amplo debate com setores mais conservadores da saúde pública e, em especial, do subsetor saúde mental. Por meio do trabalho do CAPS dispõe-se a discutir não mais "assistência psiquiátrica", mas agora, "assistência psicossocial". Nesse sentido, a implementação do CAPS nos remete a pensar a práxis do ator social que se apresenta ao trabalho naquela instituição. A antes exclusiva orientação de que caberia ao médico psiquiátrica a lógica do diagnóstico e do tratamento, passa agora a se estender para um conjunto de profissionais que irão operar pela lógica da inclusão do usuário e de suas famílias no âmbito do cuidado e da assistência. Além disso, reafirma-se o compromisso - estabelecido na orientação do Ministério da Saúde para a implementação do CAPS - de que é necessário salvaguardar o direito de ir e vir do usuário; combater qualquer atitude de estigmatização e preconceito; humanizar a atenção de forma a privilegiar a participação do usuário em seu tratamento; promover o desenvolvimento de serviços com base no território e enfatizando os anseios da comunidade, explorando mecanismo de regulação e controle social, gerando assim um espaço de abertura à prática da cidadania e inclusão social; garantir acesso aos serviços produzidos segundo uma perspectiva interdisciplinar e por meio de um coletivo multidisciplinar de agentes de saúde e centrar o trabalho de cuidado e assistência na produção de um projeto terapêutico singular. Todos estes aspectos podem ser vistos como uma síntese expressada pela orientação de um programa de saúde mental e promovida pelo SUS (BRASIL, 2004). 
Parece óbvio apontar que o avanço (teórico) registrado na lei e em seus dispositivos normatizadores não garante o êxito dos objetivos e intencionalidades ensejados no texto. A transposição daquilo que se pretende para a operacionalização no âmbito da realidade concreta - do trabalho - possui uma série de determinações que ratificam a complexidade de qualquer fenômeno social. Visto isso e tomando emprestado as ideias de Amarante (2009), é possível pensar que a instalação do CAPS promove, no bojo da discussão científica da saúde mental no Brasil, o desafio de integrar a dimensão epistemológica dos problemas que se apresentam na complexidade do fenômeno observado em torno da saúde mental à dimensão interventiva. Esta por sua vez, deve traduzir coerentemente a mesma epistemologia por meio das ações do trabalho. Com efeito, na medida em que se entra em cena novos atores, novos profissionais, novas áreas de conhecimento é necessário refletir sob quais matizes epistemológicas estas novas áreas fundamentam seus saberes a fim de contribuir no âmbito não mais da reforma psiquiátrica, mas na concretização dos argumentos vocalizados quando de sua luta histórico-política e, sobretudo, de tudo aquilo que se inscreve nos documentos que a oficializam. Seria essa coerência o aspecto central para se ver concretizado os ideais de assistência e cuidado inscritos na lei.

Sobre isso, Amarante (2009) alerta sobre a importância de se rever no âmbito da ciência de seus cânones aqueles referenciais epistêmicos que autorizavam "cientificamente" os saberes e práticas psiquiátricas, quais sejam os de produção de verdade baseados na neutralidade científica. Se não fosse assim, não teria sido possível para esta perspectiva de ciência gestar os conceitos de "alienação/doença mental, isolamento terapêutico, degeneração, normalidade/anormalidade, terapêutica e cura, dentre outros" (AMARANTE, 2009, sn). Romper com essa tradição epistemológica parece ser condição sine qua non para o início de uma efetivação do empreendimento da reforma psiquiátrica brasileira, pelo qual o CAPS pode ser um dos meios. No entanto, não está no CAPS o signo e o determinante sócio institucional que irão assegurar isso. Talvez, a resposta esteja mais relacionada com os sujeitos da prática do que com os objetos que os acercam. Senão, vejamos: 
Nesta tradição [se refere a tradição basagliana], a clínica deixaria de ser o isolamento terapêutico ou o tratamento moral pinelianos, para tornar-se criação de possibilidades, produção de sociabilidades e subjetividades. O sujeito da experiência da loucura, antes excluído do mundo da cidadania, antes incapaz de obra ou de voz, torna-se sujeito, e não objeto de saber. (AMARANTE, 2009, sn grifos nossos).

A passagem acima requer outros esclarecimentos, embora ela situe um modelo de pensamento que observamos em vários trabalhos de Amarante (1994, 1995, 1996), entre outros autores (JONES, 1972; ROTELLI, 1994; LOUGON, 1993) e que procuram resignficar a assistência e, por que não dizer, a promoção da saúde mental nos termos de um outro paradigma epistemológico que não seja aquele da psiquiatria moderna. Para esta discussão é fundamental recuperarmos a gênese da categoria de desinstitucionalização.

Mencionada en passant ao se fazer referência às influências de reformas psiquiátricas no mundo, a compreensão de desinstitucionalização a qual se refere Amarante (2009), pouco tem a ver com aquela que primeiro nos chegou observando as transformações psiquiátricas nos Estados Unidos, onde este conceito foi aplicado primeiramente. Nesse sentido, vale dizer que a experiência norte-americana vivida na década de 1960 procurou no âmbito de sua reforma defender a ideia de desinstitucionalização "[...] como um conjunto de medidas de desospitalização" (AMARANTE, 1996). Havia, como um todo, uma clara proposta pragmática de desoneração do sistema de saúde do Estado. A iniciativa estava muito mais atrelada a uma ação política de eficiência de gasto público do que com relação a uma medida que iria definitivamente transformar a natureza da assistência. Além disso, outro ponto que distingue qualitativamente a configuração da desinstitucionalização norte-americana àquela que Amarante (2009), baseado em Basaglia, quer enaltecer, tem a ver com a manutenção de uma epistemologia que continua autorizando e legitimando o saber psiquiátrico. Ou seja, a crítica (norte-americana) recai sobre a forma e não sobre o seu conteúdo. Era necessário acabar com o modelo asilar, mas não com as práticas psiquiátrica fundadas nas ciências positivistas. O corolário desse modelo 
percebido em grande medida nos tempos atuais é a crescente dependência dos psicotrópicos e o uso muitas vezes abusivo desses expedientes.

Com efeito, a desinstitucionalização, reclamada por Amarante (2009, sn grifos nossos) e a qual temos acordo,

[...] não se restringe à reestruturação técnica, de serviços, de novas e modernas terapias: torna-se um processo complexo de recolocar o problema, de reconstruir saberes e práticas, de estabelecer novas relações. Por isso, é acima de tudo, um processo ético-estético, de reconhecimento de novas situações que produzem novos sujeitos, novos sujeitos de direito e novos direitos para os sujeitos.

A evocação da "produção de novos sujeitos" e a adjetivação recursiva de sujeitos e direitos nos faz refletir e conjecturar de que o campo de conhecimento da Educação não pode deixar de atravessar os processos com os quais se pretende uma nova "ética-estética". Logo, por hipótese, abrimos a discussão de que em face à complexidade que encerra o fenômeno da saúde mental não é possível avançar, do ponto de vista epistemológico e também interventivo, sem que o esteio da Educação seja uma face obrigatória da formatação de práticas psicossociais.

Nossa hipótese se fortalece ao observar um conjunto significativo de publicações recentes e de diretrizes orientadoras da formação de agentes de saúde e profissionais de áreas afins, baseadas na saúde coletiva e em processos com alguma dimensão educativa. Por exemplo, pode-se citar o Programa de Educação pelo Trabalho para a Saúde (PET-Saúde) ${ }^{18}$ que tem sido implementando em várias universidades públicas brasileiras e orientado à produção científica de viés interventivo. O PET-Saúde tem induzido o interesse de

\footnotetext{
${ }^{18}$ O Programa de Educação pelo Trabalho para a Saúde/Vigilância em Saúde (PET-Saúde/VS) é um programa promovido pelos Ministérios da Saúde e da Educação, desenvolvido por universidades em parceria com Secretarias Estaduais e/ou Municipais de Saúde e, visa à formação do aluno através do trabalho, oferecendo oportunidades de troca de conhecimento e experiência entre profissionais que atuam no Sistema Único de Saúde (SUS) e alunos de cursos de graduação da área da saúde. (http://www.cvs.saude.sp.gov.br/ - acessado em 8 de março de 2015)
} 
jovens acadêmicos a se vincular com o trabalho em saúde mental nos CAPS (KEMPER et. al., 2015; CONCEIÇÃO et. al., 2015; ROSA, et. al., 2015).

Outro elemento importante e que sublinham nossas conclusões sobre a inserção da Educação nas práticas orientadas à assistência psicossocial tem a ver com a centralidade e o protagonismo da categoria sujeito no âmbito da discussão de reforma psiquiátrica levada a cabo por Amarante (2009). Sobre isso, cabe ressaltar que o enaltecimento do sujeito como razão das práticas psicossociais conduzem àqueles, preocupados com a centralidade do sujeito em qualquer processo de prática psicossocial, a se ater a compreensão dos aspectos que tornam o sujeito, sujeito do processo e não assujeitado a ele. Este desafio, em nossa opinião, procede a aceitação da parte dos profissionais agentes de saúde (e de educação) de que o sujeito se revela na expressão de sua subjetividade. Nesse sentido, o contexto em que se opera as práticas psicossociais precisam preservar a possibilidade de expressão de subjetividade, algo que o campo da Educação - com todos os seus limites - certamente pode empreender.

\section{O não-lugar da educação física na saúde mental: uma incipiente incursão científica}

$\mathrm{Na}$ seção anterior, foi possível perceber que os dispositivos da reforma psiquiátrica brasileira constituíram um novo modelo de assistência aos sujeitos acometidos de transtornos mentais. Isso se materializou por meio da implementação dos Centros de Atenção Psicossocial (CAPS). O CAPS desenvolve um serviço a partir da organização de um coletivo de profissionais de saúde e outras áreas que se juntam ao médico psiquiátrica e ao enfermeiro para elaborar projetos terapêuticos em saúde mental. São muitas as profissões e áreas de conhecimento possíveis de se constituírem como representantes de um 
projeto de CAPS a ser desenvolvido por uma secretaria de saúde municipal. A educação física, área protagonista em nosso estudo, é uma delas.

Assim, o objetivo que circunscreve esta última seção da fundamentação teórica, é a de apresentar os estudos científicos que compõe e sustentam a inserção da educação física na saúde mental, mais especificamente, os que têm no CAPS seus campos de pesquisa. Nesse sentido, observa-se o quão pequeno tem sido a incidência de estudos de base científica que discutem a educação física em face aos aspectos que se ligam à saúde mental. Uma busca simples na base de dados da CAPES por meio do cruzamento dos descritores "educação física" e "saúde mental" revelou pouco mais de cem produtos científicos, entre artigos, teses e dissertações, onde constam pesquisas, nem sempre compreendidas no âmbito da educação física, mas, que de alguma forma apontaram a atividade física, o corpo ou o movimento como termos chaves dos estudos. Vale dizer que quase a totalidade destes estudos promovem investigações tomando os (supostos) efeitos das atividades físicas que impactam os indivíduos acometidos por uma determinada doença mental, algo completamente fora dos propósitos de nossa investigação. Entretanto, ao filtrar as informações e restringindo a busca por pesquisas no contexto da saúde mental como subsetor da saúde pública ou os estudos que possuem alguma relação com a intervenção da educação física em CAPS, esse número cai drasticamente para apenas dois produtos. Outros trabalhos nessa temática têm sido publicados em periódicos nacionais de menor expressão e também em anais de congressos. Isso demonstra como o interesse acadêmico-científico da área sobre o tema da saúde mental é ainda bastante incipiente. De todo modo, isso é perfeitamente explicável uma vez em que é muito recente a presença dos profissionais de educação física trabalhando diretamente em CAPS. Ademais, a formação acadêmica praticamente não visualiza o espaço profissional da saúde pública como foco de atuação. Mesmo os cursos de bacharelado em educação física hegemonicamente fornecem uma formação atrelada ao trabalho no universo das academias e do fitness ou, preferem ainda, uma formação orientada ao treinamento esportivo. A saúde pública e, por consequência, a formação para a 
saúde mental tem sido ofertada por inciativa de poucos professores, geralmente, aqueles que têm pesquisado mais recentemente sobre a temática.

De todo modo, é possível discutir sobre as tendências dessas pesquisas já constituídas. Se por um lado, percebe-se uma discussão incipiente do ponto de vista quantitativo, por outro, o conteúdo de alguns trabalhos dão indícios de que a educação física pode produzir ideias qualitativamente fundadas nas demandas e desafios que a reforma psiquiátrica brasileira ensejou.

Isso é perfeitamente observável no trabalho pioneiro de Wachs e Fraga (2009) já antes mencionado aqui, mas não desdobrado. Nesta pesquisa, o trabalho da educação física realizado por meio de oficinas foi acompanhado em três diferentes CAPS e tinha como objetivo compreender o que se tem feito "[...] em nome da educação física nos CAPS, bem como os sentidos que lá circulam sobre a presença de professores de educação física e sobre as práticas por eles desenvolvidas" (WACHS, FRAGA, 2009, p.94). Dois aspectos importantes são levantados ao final do estudo e que merecem destaque. O primeiro tem a ver com a necessidade de se refletir sobre quais seriam os determinantes orientadores da prática dos professores de educação física para o serviço psicossocial. Nesse ponto, os autores discutem a importância de produzir práticas que emerjam no próprio CAPS e não aquelas impostas pela própria educação física. A autoridade da educação física e a legitimidade como área de conhecimento presente no CAPS se daria em face as formas que ela conseguiria responder às demandas expostas pelos usuários e sua instalação como uma área que potencialize o trabalho interdisciplinar. O segundo aspecto especula sobre a forma como a presença da educação física em CAPS contribui para o modelo de desinstitucionalização na medida em que pode ofertar propostas pedagógicas de orientação do e para o corpo com vista a desenvolver ações de autonomia para os usuários.

Em Wachs e Fraga (2009) observa-se uma preocupação com um conjunto de informações instituídas como dados de pesquisa revelam alguma preocupação com a produção de subjetividades naquele espaço social. Isso se torna relevante para a conclusão que os autores chegam em apontar que a práticas da educação física subjazem as necessidades e objetivos do CAPS. O estudo de Roble, 
Moreira e Scagliusi (2012) acrescentam ao debate das formas de atuação da educação física em CAPS outros elementos. Em nossa opinião, estes autores chegam a conclusões que corroboram aquelas defendidas por Wachs e Fraga (2009) no que diz respeito à orientação das práticas promovidas pela educação física. Em Roble, Moreira e Scagliusi (2012, p.570) o objetivo foi o de promover uma experiência curricular na formação acadêmica inicial de estudantes de educação física. No caso, "[...] alunos de terceiro ano dos cursos de Psicologia, Nutrição, Terapia Ocupacional, Fisioterapia e Educação Física formam equipes, que, junto com os docentes de tais cursos, desenvolvem projetos terapêuticos em serviços de saúde [...]" na rede pública. Os estudantes da educação física se inseriram em um Núcleo de Atenção Psicossocial (NAPS) e além de promoverem um trabalho em educação física com os usuários, elaboraram registros dessas experiências que foram tomadas como dados de pesquisa. Ao ouvirem os usuários, os estudantes compreenderam que havia um contexto de tendência ao sedentarismo da parte deles e que o projeto terapêutico deveria atender a esta demanda.

Outros estudos que possuem base empírica e situam o cenário do CAPS como lócus de investigação e as práticas laborais da educação física como objeto vão ao encontro destes dois últimos no que se refere ao debate sobre a atuação da educação física na saúde mental, como é o caso de Abib et. al. (2010), Lírio (2011), Guimarães et. al. (2012), Silva et. al. (2014). Veit e Rosa (2015).

A pesquisa de Furtado et. al. (2015, p.51), por sua vez, procura relativizar o êxito do trabalho dos professores de educação física em CAPS. Ao contrário dos demais trabalhos, embora se ratifique a legitimidade da área em consonância aos objetivos do modelo de assistência psicossocial, o estudo reflete os desafios que as condições estruturantes de trabalho em saúde mental impõem à educação física. Nesse sentido, os autores concluem que "os profissionais ainda estão aprendendo a lidar com os novos desafios".

Em todos os trabalhos é possível verificar em comum o esforço de apropriação ao processo histórico de luta por uma nova concepção de assistência ao transtorno psíquico. É perceptível que há uma base teórica que respeita os referenciais críticos da saúde pública e os fundamentos da reforma psiquiátrica 
brasileira. Nesse sentido, a gênese da aproximação da educação física ao trabalho em saúde mental no setor público situa-se de forma coerente com os anseios teóricos e práticos de uma perspectiva ampliada de saúde. Observa-se nestas poucas pesquisas que o trabalho com as práticas corporais tem se preocupado mais com os sujeitos da prática do que com a doença. Na relação histórica da educação física com a saúde, isso certamente é um avanço e acompanha o discurso progressista da área.

Algo ainda a se explorar tem a ver com o núcleo teórico desta tese. Os trabalhos não objetivam acessar ou explorar a produção de subjetividades dos atores e sujeitos envolvidos às práticas da educação física. Outrossim, surge uma lacuna teórica que, nos limites do desenvolvimento de qualquer pesquisa, nosso estudo ansiou desenvolver. 


\section{III - METODOLOGIA}

O que me motiva é a preocupação de ocultar o menos possível a complexidade do real.

Edgar Morin

Você replicará que a realidade não tem a menor obrigação de ser interessante. Eu the replicarei que a realidade pode prescindir dessa obrigação, mas não as hipóteses.

Jorge Luis Borges 


\section{Fundamentos Teóricos da Epistemologia Qualitativa: a prática da construção de uma outra racionalidade}

Observando os estudos de González Rey (1997, 2005a, 2005b, 2005d), compreendemos a Epistemologia Qualitativa como a expressão metodológica e epistemológica da Teoria da Subjetividade numa perspectiva cultural-histórica. Ela se apresenta como uma possibilidade científica aos estudos que procuram compreender a dimensão subjetiva de um fenômeno que se caracteriza ontologicamente como complexa. É, diante disso, a representação contrahegemônica ao cientificismo, ao positivismo e ao racionalismo.

Embora não esteja explícito em seus trabalhos, não sendo possível assim apontar a sua influência, percebemos algumas aproximações da crítica ao cientificismo e ao racionalismo promovidas por Feyerabend (2011), às inspirações dos fundamentos teóricos da Epistemologia Qualitativa de González Rey. No caso, González Rey (2005d) parece concordar quanto à crítica aos parâmetros inexoráveis da tradição científica moderna apresentados por Feyerabend. Entendemos, entretanto, que em González Rey (2005d) uma via epistemológica animadora se apresenta à constituição de uma nova racionalidade. À guisa de debate epistemológico, apresentamos a seguir uma ligeira discussão sobre isso. Tal discussão serve-nos como mote temático para introduzirmos em síntese os pressupostos teóricos da Epistemologia Qualitativa.

O físico austríaco Paul Feyerabend (1924 - 1994) ganhou grande notoriedade no âmbito da filosofia da ciência a partir da polêmica obra "Contra o método" publicado em 1974, no qual promove uma contundente crítica à forma hegemônica de se pensar a ciência, rejeitando por completo as implacáveis e atomísticas regras metodológicas que compõe o tradicional pensamento científico empirista, e propõe aquilo que ficou conhecido como "anarquismo epistemológico". De alguma forma, essa virada "contra o método" só é possível dado seu ecletismo de formação. Doutor em física, pela Universidade de Viena, doutor honoris causa em Letras e Humanidades pela Universidade de Chicago e profundo conhecedor de teatro, tendo sido assistente de Berthold Brecht (REGNER, 1996). 
Para Feyerabend todos os mecanismos reguladores do ponto de vista metodológico da pesquisa prejudicam severamente os processos criativos que engendram o avanço do conhecimento. Para ele a ciência só empreenderá êxitos na medida em que se aceita procedimentos ditos "anárquicos". Nesse sentido, declara:

Para os que examinam o rico material fornecido pela história (da ciência) e não tem a intenção de empobrecê-lo a fim de agradar a seus baixos instintos, a seu anseio por segurança intelectual na forma de clareza, precisão, "objetividade" e "verdade", ficará claro que há apenas um princípio que pode ser defendido em todas as circunstâncias e em todos os estágios do desenvolvimento humano. É o princípio de que tudo vale. (FEYERABEND, p.42, 2011).

De fato, a utilização de termos como "anarquismo" e "tudo vale" podem levar a uma compreensão limitada do alcance da crítica de Feyerabend ao racionalismo como mote central e definidor de fronteiras da ciência. Aplicados à epistemologia, o anarquismo não significa ser contra todo e qualquer procedimento metodológico mas, antes, a oposição a um único e imutável princípio. O "tudo vale" pode ser visto como uma reação, nessa mesma direção, no sentido de apontar para o fato de que todas as metodologias possuem limitações (COSTA; KIPNIS, 2015).

Para Feyerabend, a ciência, e junto a racionalidade científica, constitui-se em mais uma ideologia junto com outras trazidas pelos mitos, dogmas e afirmações metafísicas, que não deve ter preponderância alguma na construção de uma cosmovisão. Em um estado democrático, a convivência dessas diferentes ideologias seria saudável para o desenvolvimento dos indivíduos e da sociedade. Essa suposta superioridade da ciência significa colocá-la como medida objetiva de todas as ideologias a partir do fato, da lógica e do método científico. Esse autor não propõe uma teoria da ciência, mas critica o método científico exclusivamente baseado no conceito de racionalidade, deixando em aberto a possibilidade de se construir uma racionalidade contextualizada capaz de ampliar 
nossa humanidade, nossa consciência e nos aproximar de uma visão do conhecimento mais aberta (COSTA; KIPNIS, 2015).

Arriscamos dizer que a visão epistemológica de González Rey tem contribuído significativamente para essa possibilidade de "construção de uma racionalidade contextualizada", sobretudo porque corrobora as ideias de Feyerabend sobre o racionalismo procurando, entretanto, ressignificar a razão científica no abandono da dicotomia do empírico e do teórico que o cientificismo maculou, sendo o primeiro a representação da realidade externa e o segundo a especulação abstrata ou a mera descrição do empírico. Nesse sentido escreve González Rey (2005d, p.9):

Se rompermos com a ideia de que a realidade é um sistema externo, [...] e consideramos nossas práticas como algo constitutivo, mas também constituinte dos campos por nós estudados, a única maneira de construir um espaço de realidade como conhecimento é valer-se de nossas práticas científicas, as quais são fundadoras de novos campos de realidade; nesses campos, a infinita complexidade da realidade é suscetível, por meio de tais práticas científicas, de multiplicar-se em várias formas de inteligibilidade as quais, embora nos permitam visualizar a realidade, o fazem de modo limitado por causa dos próprios meios que usamos. Dessa forma rompe-se a expectativa racionalista de que o mundo pode ser conhecido de forma completa e progressiva pela razão humana. A racionalidade é, ao contrário, a forma com que temos para produzir inteligibilidade em sistemas, os quais, por sua complexidade, escapam dos meios utilizados por nós para conhecê-los.

Logo, para este autor, os limites metodológicos - como apontava Feyerabend - estão implicados na própria constituição da realidade complexa. Todavia, ao se aceitar essa dita realidade complexa não podemos cair na armadilha do discurso abstrato ou de significá-la como "complicada" e "confusa". A "saída" para a ciência, portanto, passa ao entendimento de que os pesquisadores precisarão incansavelmente definir ontologicamente um sistema de realidade com o qual estabelecerá relações com os objetivos aventados, ciente de que a sua subjetividade está implicada nesse processo. O resultado disso, ensina González Rey (2005d, p.17), é que "as características gerais de um sistema complexo devem adquirir valor heurístico para construir o conhecimento 
dentro do campo por nós estudado". Com efeito, a reclamada racionalidade contextualizada e aqui reafirmada, mostra-se explícita em González Rey (2005d, p.29) em sua compreensão de pesquisa e de como a teoria deve ser ressignificada $^{19}$ :

[...] consideramos a pesquisa qualitativa uma via essencial para a produção de teoria, isto é, para a construção de modelos teóricos de inteligibilidade no estudo de sistemas que não são diretamente acessíveis, nem em sua organização, nem nos processos que os caracterizam à observação externa; definimos a teoria como a construção de um sistema de representações capaz de articular diferentes categorias entre si e gerar inteligibilidade sobre o que se pretende conhecer na pesquisa científica. Tal sistema de representações cede espaço à organização intelectual de um campo, o qual se expressa em uma representação com capacidade de integrar novos aspectos do estudado no desenvolvimento de uma linha de pesquisa.

Sobre esses apontamentos González Rey (2005d) edificou a Epistemologia Qualitativa, em que a teoria é sempre um sistema aberto que integra tanto representações teóricas gerais do pesquisador como os momentos empíricos de sua pesquisa. Para ele, o empírico é ocasião em que o teórico se confronta com a realidade, e por isso são indissociáveis. Em González Rey (2005d, p.30) encontramos que o empírico (na pesquisa) "é a informação da realidade que entra em contradição com o teórico e que permite sua extensão e crescimento". A teoria, portanto, apresenta-se como facilitador e limitador da percepção dos fenômenos empíricos. Por esse motivo, a necessária mediação reflexiva do pesquisador deve tornar-se sujeito desse processo a fim de lograr êxito na produção de um modelo teórico, consagrando-se como o núcleo gerador do pensamento.

O nascimento da terminologia "Epistemologia Qualitativa" merece alguns esclarecimentos. A proposta foi assim denominada a partir da publicação da obra Epistemología Cualitativa y Subjetividad em 1997. Foi cunhada por González Rey procurando se aproximar qualitativamente dos estudos do campo da psicologia e das ciências antropossociais ao mesmo tempo em que radicalmente se

\footnotetext{
${ }^{19} \mathrm{~A}$ análise do autor se refere às ciências antropossociais.
} 
apresentasse como opositora das características ateóricas impostas pela tradição do positivismo que impôs a prática de pesquisa fundada no modelo de descrição e quantificação de dados só possíveis de serem validados por meio de estatística (González Rey, 2005d). A objeção ao positivismo se dava na medida em que este foi assimilado pela psicologia negando o seu principal objeto: a subjetividade. Se por um lado a abordagem da pesquisa qualitativa mostrou-se um importante elemento de confrontação à dominação do positivismo, por outro, a adesão a esta abordagem de pesquisa foi, segundo González Rey (2005d), paulatinamente sendo corrompida pelo instrumentalismo que consagrou a técnica em detrimento à reflexão, reificando o empírico e hipertrofiando a produção teórica. Talvez pudéssemos referenciar novamente Feyerabend: o problema era epistemológico que implicava desvios metodológicos. Grosso modo, a diferença entre os dois é de ordem propositiva.

O objeto de estudo de González Rey é a subjetividade. Herdada do pensamento vivo, aberto e contraditório de Vygotsky, o autor compreendeu que as diversas mudanças que acompanham o conceito de subjetividade pressupõem também mudanças do ponto de vista epistemológico e metodológico que por sua vez, contribuem no sentido de desenvolver o conceito e desdobrar novas categorias. Dito de outra forma, a subjetividade numa perspectiva culturalhistórica requer um novo pensar e fazer científico. Dito isso, podemos dizer que a Epistemologia Qualitativa abre um horizonte metodológico no âmbito da pesquisa qualitativa aos estudos nas ciências antropossociais de forma inovadora. Uma síntese possível na apresentação da Epistemologia Qualitativa pode ser assim destacada: a) a pesquisa pressupõe um caráter construtivo-interpretativo do conhecimento; b) a legitimação do singular como produção de conhecimento; c) o processo de comunicação e a dialogicidade como característica particular das ciências antropossociais.

Sobre o caráter construtivo-interpretativo do conhecimento, González Rey (2005d, p.6) assim se expressa:

[...] desejamos enfatizar que o conhecimento é uma construção, uma produção humana, e não algo que está pronto para conhecer uma realidade ordenada de acordo com as categorias universais do conhecimento. Disso surgiu o conceito de "zona de sentido", 
definido por nós como aqueles espaços de inteligibilidade que se produzem na pesquisa científica e não esgotam a questão que significam, senão que pelo contrário, abrem a possibilidade de seguir aprofundando um campo de construção teórica. Tal conceito tem, então, uma profunda significação epistemológica que confere valor ao conhecimento, não por sua correspondência linear ou imediata com o "real", mas por sua capacidade de gerar campos de inteligibilidade que possibilitem tanto o surgimento de novas zonas de ação sobre a realidade, como de novos caminhos de trânsito dentro dela através de nossas representações teóricas.

Assim, o conhecimento científico se dá pela sua capacidade de permanecer reativo à confrontação de novos pensamentos que se processam nas experiências com o empírico. Sobre esse princípio, o autor alerta para a necessária diferenciação entre os termos interpretação e construção já que o primeiro implica o segundo. Embora o empírico seja um aspecto relevante na Epistemologia Qualitativa, a ideia de construção estabelecida nesta discussão não se associa obrigatoriamente a um referencial empírico. Nesse sentido, a construção de uma categoria conceitual tem caráter especulativo, "a construção é um processo eminentemente teórico" (González Rey, 2005d, p.7). Logo, a Epistemologia Qualitativa oferece uma metodologia orientada pela busca de produção teórica sobre um determinado fenômeno ou, como prefere o autor, de modelos teóricos de inteligibilidade.

A valorização da característica teórica da pesquisa fundada na Epistemologia Qualitativa é fator preponderante para que se estabeleça a legitimação do singular como fonte de conhecimento científico. Esse relevante aspecto da Epistemologia Qualitativa representa uma severa inflexão a como a psicologia e as ciências antropossociais tradicionalmente legitimam a cientificidade do conhecimento, que hipervalorizam o procedimento técnico que "colhe" dados do empírico em detrimento da reflexão criativa do pesquisador. Registra-se que a lógica de "coletar dados" - expressão chavônica na ciência merece uma análise crítica com a qual podemos redefini-la à luz da produção teórica nas ciências antropossociais:

[...] o dado, mais que uma expressão de respeito à realidade tal qual ela se apresenta, argumento que tem apoiado os autores positivistas a sustentarem a legitimidade do caráter científico da pesquisa, representa a primeira grande evidência de que qualquer 
aproximação à realidade é, inevitavelmente, uma expressão do conceito de realidade que precede e organiza tal aproximação. Portanto, fora a definição ontológica e epistemológica em que o conceito de dado definiu seu valor, não há nenhum sentido em continuar definindo a coleta de dados como uma etapa da pesquisa: em primeiro lugar, porque realmente os dados não se coletam, mas se produzem e, em segundo lugar, porque o dado é inseparável do processo de construção teórica no qual adquire legitimidade. (GONZÁLEZ REY, 2005d, p.100).

Ao pensar nesses termos, González Rey (2005d) inverte o critério de legitimidade científica do nível empírico para o nível teórico, sendo este somente possível caso a singularidade do trabalho pensante do pesquisador se situe como núcleo da produção de conhecimento. O material empírico integra as ideias do pesquisador e são organizados num tecido metodológico com o qual 0 pesquisador se mantém protagonista no curso da pesquisa e nunca refém. A preservação desse processo é que dá legitimidade ao conhecimento produzido. Logo, o pesquisador está implicado intelectualmente na pesquisa e "a informação única que o caso singular nos reporta não tem outra via de legitimidade que não seja sua pertinência e seu aporte ao sistema teórico que está sendo produzido na pesquisa" (GONZÁLEZ REY, 2005d, p.12).

A negação do instrumentalismo na Epistemologia Qualitativa se evidencia pela comunicação e o dialógico como vias privilegiadas para se conhecer a subjetividade, tendo nelas o eixo metodológico particular nas ciências antropossociais. Porém, alguns apontamentos se tornam necessários no sentido de diferenciação de outras abordagens de pesquisa que têm na comunicação o foco central para a construção de conhecimento. Nesse sentido, entendemos como obrigatória a leitura da seguinte passagem em González Rey (2005d, p.14):

O lugar que atribuímos à comunicação como espaço primordial para a manifestação do sujeito crítico e criativo na pesquisa tem, de fato, um papel essencial para superar o que denominamos [...] Epistemologia da Resposta, a qual é, em realidade, uma reprodução, em termos epistemológicos, do princípio estímuloresposta dominante durante toda a primeira metade do século $X X$ na construção do pensamento psicológico. A metodologia, em sua concepção instrumental, apresentou-se como sequência de estímulos, seja pranchas, perguntas, sensações seja outros que, organizados em determinados procedimentos, procuravam a resposta do sujeito como unidade de informação essencial para a 
construção do conhecimento. A Epistemologia Qualitativa procura subverter tal princípio e converter a produção do sujeito, o complexo tecido informacional que este produz por diferentes caminhos, no material privilegiado para construir 0 conhecimento, rompendo assim com um dos princípios mais arraigados do imaginário da pesquisa ocidental: o fato de compreender a pesquisa, em sua parte instrumental, como a aplicação de uma sequência de instrumentos, cujos resultados parciais serão a fonte do resultado final. (GONZÁLEZ REY, 2005d, p.14-15 - grifo nosso).

A subversão reclamada pelo autor tem como princípio o completo distanciamento de qualquer tipo de apriorismo instrumental ou categorial no processo de produção da informação. Os sujeitos da pesquisa precisam estar assim como o pesquisador - implicados em sua subjetividade no curso da pesquisa, tornando-se não mais um "conjunto da amostra", mas sim, efetivos colaboradores de pesquisa. Ademais, a lógica estímulo-resposta dos instrumentos padronizados denunciados na passagem acima, também evidenciam a completa desconsideração dos elementos sociais constituidores do contexto metodológico, fato que a Epistemologia Qualitativa procura romper ressignificando a definição de instrumento nos seguintes termos: a) o instrumento é um meio para provocar a expressão do sujeito; b) o instrumento é apenas uma fonte de informação que deve estar separada de qualquer categoria teórica pré-estabelecida; c) os instrumentos precisam possuir articulação interna perfazendo um sistema integrado; d) os instrumentos subjazem as expressões simbólicas e singulares dos sujeitos; e) os instrumentos precisam ter potencial de envolvimento emocional dos sujeitos, aspecto fundamental para a produção de sentido subjetivo; f) os instrumentos não possuem regras padronizadas de elaboração.

Por fim, é válido registrar que a pesquisa que toma por base a Epistemologia Qualitativa como referencial metodológico, está circunscrevendo o seu estudo à dinâmica da subjetividade como significação ontológica do conhecimento. Portanto, é mister afirmar que o anseio fundante das ideias aqui apresentadas transcendem qualquer perspectiva pragmática da metodologia científica. Destarte, procurou-se com elas ter no qualitativo a expressão maior da discussão epistemológica na psicologia e nas ciências antropossociais. 
Em nosso caso, foi deliberada a intenção em proceder com este estudo sob a orientação da Epistemologia Qualitativa, mesmo observando as inúmeras dificuldades que a apropriação dela impõe. De todo modo, temos clara a percepção de que o método não pode se estabelecer como um caminho inexorável e rígido e que em seguindo-o, chegamos a um conhecimento que já estava pronto, precisando apenas ser revelado. Com efeito, concordamos com González Rey (2005d, p.202) que para o conhecimento "existem múltiplas alternativas de inteligibilidade e significação na construção de realidades que, como a subjetividade, são complexas". Assim, cabe-nos sermos rigorosos em expressar sobre aquilo que foi vivido, como explorarmos nossa produção de sentido subjetivo no curso da pesquisa, quando invocamos uma possibilidade de percurso metodológico. É o que passamos a fazer nas próximas seções desse trabalho.

\section{O processo de construção do cenário de pesquisa}

A dinâmica metodológica na qual se apoiou esta pesquisa responde aos fundamentos da Epistemologia Qualitativa, a qual sumariamos na seção anterior. Diante dessa orientação é fundamental registrar como se efetivou o processo do percurso metodológico no âmbito das relações humanas e da produção de subjetividades de quem pesquisa e de quem participa e colabora de alguma forma com o estudo. Aceitar tal opção epistemológica exige que o pesquisador rompa com a lógica fragmentada e fechada em torno de um método de características inexoráveis, entendendo dessa forma que o método também possui um caráter processual. Logo, a produção de conhecimento que segue esta perspectiva qualitativa compreende que esse processo metodológico ocorre "numa desordenada e complexa interação entre os mundos conceitual e empírico, em que a dedução e a indução ocorrem ao mesmo tempo" (BECHHOFER, 1974, p.73 apud GONZÁLEZ REY, 2005b, p.67). Frente a isso, González Rey (2005d) recomenda como necessário proceder sobre um conjunto de ações estratégicas à 
configuração da pesquisa no que tange a aproximação do locus social do estudo e que se efetiva por meio da construção de relações pessoais no qual o objetivo é construir uma rede de envolvimento emocional por parte de pesquisadores e sujeitos colaboradores da pesquisa. Trata-se de um cuidado extremamente importante de preparação e contínua vivencia no campo de pesquisa. Em outras palavras, seria uma forma explícita de se qualificar o momento empírico. Além disso, González Rey (2005d) defende que a produção de sentido subjetivo, fator caro aos estudos da subjetividade, está condicionada a um contexto em que os sujeitos da ação (pesquisadores e colaboradores) se mostram envolvidos emocionalmente em determinado momento do estudo e, assim, implicados por suas subjetividades. Por isso se torna imprescindível os esclarecimentos que seguem esta seção.

A trama de uma pesquisa, circunscrita à Epistemologia Qualitativa, legitima o contingencial como aspecto característico da expressão de complexidade dos fenômenos humanos. O contingencial, que para algumas correntes metodológicas devem (e podem) ser previstos na Epistemologia Qualitativa é a expressão de que o pesquisador se integra de fato ao campo. Isto quer dizer que não o domina, não o apreende e não o controla. O pesquisador, nesse sentido e em se tratando dos fenômenos sociais, "vive" o campo e está sujeito às contingências que a complexidade do campo encerra. As vicissitudes que perfazem o percurso metodológico não são fatores que fragilizam o estudo. Ao contrário, são aspectos do vivido que demonstram o quanto a pesquisa social assume condição de honestidade científica que compreende a fluidez do espaço social e sua ambivalência como aspectos que devem traduzir a complexidade dos fenômenos sociais. Estas reflexões são importantes para apresentar, de uma forma geral, os entraves e os novos rumos que nossa pesquisa tomou no processo de realização. Vale ainda dizer que os entraves não determinam o (não) alcance de objetivos antes aventados. No caso, os entraves retroalimentam a pesquisa, fornecem novos elementos que reconfiguram os objetivos e enriquecem o estudo nos termos de um fenômeno complexo.

Em campo, nosso objetivo era o de acompanhar o trabalho efetivado por um professor de educação física em algumas oficinas terapêuticas promovidas 
por este professor, bem como vivenciar toda a rotina de trabalho do CAPS como a acolhida, reuniões coletivas dos profissionais, eventos da instituição entre outras atividades. O vínculo criado com este professor facilitou enormemente nossa chegada a esta unidade do CAPS. O professor de educação física, agora sujeito colaborador de nossa investigação, possuía um bom trânsito junto à direção do CAPS de forma que nossa aceitação foi imediata. Nossa presença, antes vista como uma visita que visava uma investigação científica, aos poucos foi se transformando numa iniciativa que auxiliava e contribuía no trabalho. Nossa participação nas reuniões multiprofissionais nos levaram a perceber nestes espaços, momentos extremamente valiosos para a construção de informação. Assim, estabelecemos as quintas e sextas-feiras como nossos dias de presença no CAPS e isso se concretizou ao longo de 4 meses (fevereiro à maio de 2015).

No início de maio de 2015, a cidade do CAPS investigado viveu uma conjuntura política bastante tensa no que diz respeito ao conjunto de mobilizações político-sindicais de várias classes trabalhistas do serviço público. Asseverava-se ali um pacto dos servidores que lutavam por melhores condições de trabalho bem como estruturação da carreira. O setor educação deflagrou greve que logo foi acompanhada pelo setor saúde. A unidade do CAPS, na qual estávamos realizando a pesquisa, teve adesão total de seus servidores, exceto os cargos de gerência. Isso resultou na suspensão dos serviços terapêuticos destinados ao atendimento de usuários. Passado um mês de greve, era necessário tomar uma decisão frente à continuidade e os rumos da pesquisa e nossa inserção naquele cenário. Embora fossemos sensíveis e solidários aos profissionais do CAPS, aquela conjuntura fugia aos escopos de nossa diligência. O tenso ambiente nas constantes manifestações contra o governo do estado mantinha um clima de completa indecisão frente aos encaminhamentos futuros que sinalizasse o fim da greve. No início de junho, ainda sem uma definição do fim da greve, tomamos a decisão de alterar (ou somar outro) o cenário de pesquisa, embora tal decisão não tenha considerado a incompletude da experiência vivida como um determinante nessa decisão.

Havíamos produzido um conjunto substancial de informações na experiência vivida em meio àquele cenário. Encaminhávamos a possibilidade de 
elaborar nosso modelo teórico frente àquilo que íamos projetando em face à empiria do trabalho de campo. Entretanto, tais informações produzidas nestes momentos empíricos eram pressionadas pela continuidade dos estudos teóricos em torno da Teoria da Subjetividade e da Epistemologia Qualitativa. Havíamos circunscrito o professor de educação física como sujeito colaborador do estudo e sua atuação em saúde mental como foco de nossos objetivos. Obviamente, existem outros atores não menos importantes naquele cenário social produzindo novas configurações subjetivas fundamentais para se pensar a atuação. Ou seja, o foco em um perfil de sujeito, no caso o professor de educação física, não determina que a produção de informação venha somente a partir das ações desse sujeito. Ao refletir sobre a teoria, entendíamos que a produção de sentido subjetivo, embora vinculado à singularidade do sujeito que a produz observando sua historicidade e cultura, não se isola à subjetividade social de um cenário. Não se trata de isolar o sujeito, mesmo porque sua atuação é sempre em relação aos outros sujeitos, seja com seus colegas profissionais ou com os usuários. Naquele momento da pesquisa, não era só a greve que fomentava as vicissitudes de nossa investigação. A própria empiria somada ao amadurecimento teórico forjava em nós a necessidade de romper com aquilo que antes pretendíamos como processo de pesquisa e de construção de seu cenário.

Particularmente, precisávamos nos aproximar dos usuários. Nessa primeira experiência em CAPS, nossa implicação sempre permaneceu junto aos profissionais e servidores do CAPS, não aos usuários. Nosso relacionamento com os usuários se restringia aos momentos de acompanhamento da oficina terapêutica promovida pelo professor de educação física. Entretanto, refletíamos sobre indicadores que nos pressionava a avançar também em ideias que permeavam a produção de sentido subjetivo dos usuários que participavam de forma bastante comprometida na oficina.

Assim, aquela conjuntura de interrupção da pesquisa em função da greve nos forçava a decidir rapidamente sobre os novos encaminhamentos para o momento empírico. Contudo, a decisão nos pareceu qualificar o estudo. Alteramos o cenário social da investigação e refletimos sobre a pretensão de incorporar novos objetivos específicos à vinculação das configurações subjetivas 
advindas dos sujeitos que, como usuários do CAPS, participam ativamente de uma oficina de práticas corporais. Tal alteração buscou uma nova unidade de CAPS, procurando agora explorar e criar um vínculo afetivo-emocional com os usuários. Nesse sentido, não abandonamos os objetivos sobre o refletir a atuação e o trabalho do professor de educação física em CAPS, mas sim, incorporar um objetivo a mais. O momento empírico do CAPS resultou em um dos eixos temáticos da elaboração da construção da informação desta tese, intitulada “Configurações subjetivas da atuação do profissional de educação física em CAPS: dilemas e desafios" e será apresentada na continuidade do presente trabalho.

Constituir novo cenário de pesquisa, embora ainda em um CAPS, resultava em outras diligências. Entretanto, isso jamais foi elemento de apreensão. Contávamos com o auxílio do pesquisador Daniel Goulart ${ }^{20}$ que havia defendido sua dissertação de mestrado e tomado como tema de pesquisa a saúde mental. Goulart foi fundamental para que fossemos muito rapidamente acolhidos numa outra unidade de CAPS. A pesquisa de Goulart, que teve esse CAPS como cenário social, havia gerado entre os seus profissionais um sentimento de muita admiração pelo pesquisador. O referencial teórico da pesquisa, suas intenções e sua sensibilidade como pesquisador, forjaram em Goulart um referencial que transcendeu a própria pesquisa. Sua vinculação a este CAPS passou a se constituir de forma mais sistemática. Ao saber de nosso interesse em conduzir a pesquisa em CAPS, de imediato Goulart se prontificou a mediar esse processo frente àquela unidade que já o havia acolhido. Nessa ocasião, por conta de seu trabalho com investigador naquele cenário e o êxito dele junto aos profissionais do CAPS, Goulart agora realizava um trabalho voluntário junto à gerência e coordenação com vistas à formação continuada dos profissionais de saúde que lá atuavam. Foi em meio a este trabalho que Goulart nos conduziu ao (novo) CAPS, no qual almejávamos dar continuidade ao momento empírico deste estudo.

\footnotetext{
${ }^{20}$ Pesquisador do grupo "A subjetividade na Educação e na Saúde", sediado na UnB e liderado pelo Prof. González Rey, defendeu dissertação de mestrado em 2013 intitulada "Institucionalização, subjetividade e desenvolvimento humano: abrindo caminhos entre educação e saúde mental".
} 
Assim, em meados de junho de 2015 iniciamos nosso processo de aproximação a este "novo" cenário de pesquisa. Em função do contexto mencionado acima, fomos extremamente bem acolhidos. Eles viam em nós uma extensão da competência demonstrada por Goulart. Em pouco tempo havíamos conhecido todos os sujeitos que trabalhavam neste CAPS.

De todo modo, a construção do cenário de pesquisa neste segundo CAPS possuía outros desafios para o estudo. Nós estávamos cônscios de que não havia a figura do professor de educação física trabalhando neste CAPS. O projeto de CAPS instituído na Secretaria de Estado de Saúde daquela cidade não contempla a contratação de professores de educação física para atuar em CAPS. Entretanto, gostaríamos de fundar nossa presença nos aproximando dos usuários. Além disso, sabíamos que neste CAPS havia algumas intervenções motivadas por práticas corporais, como era o caso de uma oficina de futebol e que tinha como mediadora uma técnica em enfermagem. Outras oficinas tinham como estratégia de trabalho o vínculo com atividades que explorassem o corpo. Como era o caso da dança realizada por uma voluntária com formação em artes cênicas. O fato é que desde a experiência anterior, percebíamos a carência e o desejo de que os projetos terapêuticos incluíssem uma agenda para as práticas corporais. Nossa saída na ausência de um profissional com vínculo efetivo de trabalho em CAPS e que fosse da área de educação física, foi nos oferecermos como pesquisadores e voluntários para compor a equipe desses profissionais, num espaço onde foi necessário nosso conhecimento acerca da educação física. Naturalmente nos aproximamos da oficina de futebol e lá fomos muito bem acolhidos. Em nenhum momento ocupamos o lugar da pessoa que lá mediava e organizava a oficina e tão pouco nos colocamos como sujeito detentores de um conhecimento alheio àqueles profissionais. Nossa inserção foi paulatina e sempre auxiliando no processo, de forma coadjuvante na centralidade da oficina, mas protagonista na aproximação com os usuários, foco desse novo momento de pesquisa.

Participar da oficina de futebol foi incorporando novos indicadores à pesquisa e que certamente promoveram discussões que levam a pensar a atuação da educação física na saúde mental. Ou seja, não se tratou assim, de um "desvio" do estudo em face às contingências do momento empírico. Vivemos 
nessa nova construção a absorção de um contexto que favorece e retroalimenta nossas construções teóricas, só que agora, enriquecidas dos sujeitos a quem se destina a prática do professor de educação física. Assim, novos sujeitos colaboradores do estudo se somaram ao trabalho, e em especial, três sujeitos que serão apresentados mais adiante. Em termos cronológicos, essa experiência se deu entre junho à novembro de 2015, com a oficina de futebol acontecendo uma vez por semana, às quintas-feiras. Nossa presença transcendeu esse tempo, na medida em que também estivemos presentes em algumas reuniões da equipe profissional e em outras oficinas com a intenção de reconhecer melhor aquele cenário social. Os desdobramentos dessa experiência foram incorporados em nosso modelo teórico e resultaram na elaboração de um segundo eixo temático da tese e que se apresenta com o título de "Configurações subjetivas da prática da educação física em CAPS: produção de sentido em quem vive às práticas corporais".

As seções que seguem, apresentam os locais da investigação, os instrumentos de pesquisa que foram fundamentais para a produção de informação bem como os sujeitos-colaboradores do estudo. Na Epistemologia Qualitativa, a organização em separado destes aspectos jamais pode aludir a uma compreensão fragmentada do todo da pesquisa. É necessário procurar criar uma organicidade entre tais estruturas de texto mesmo que seja um desafio à escrita científica. Nos limites de nossa compreensão teórica frente a esta perspectiva epistemológica, é o que procuramos fazer na sequência.

\section{O locus da investigação: o Centro de Atenção Psicossocial (CAPS)}

O CAPS é uma unidade de saúde que presta serviço à comunidade por meio do Sistema Único de Saúde (SUS), tratando de pessoas que sofrem de transtornos mentais, psicose, neuroses graves e demais quadros que justifique cuidados intensivos e personalizados. O CAPS tem como objetivo oferecer 
atendimento à população de sua área de abrangência, realizando o acompanhamento clínico e a reinserção social dos usuários pelo acesso ao trabalho, lazer, exercício dos direitos civis e fortalecimento dos laços familiares e comunitários. É um serviço de atendimento de saúde mental criado para ser substitutivo às internações em hospitais psiquiátricos no Brasil. (BRASIL, 2004).

As unidades do CAPS são montadas observando a necessidade de cada distrito sanitário ${ }^{21}$ da cidade, em espaços próprios e preparados adequadamente ao atendimento às suas demandas específicas. Precisa possuir consultórios para atividades individuais e em grupos, espaços de convivência, refeitório, sanitários, áreas externas para oficinas e práticas de esporte e lazer (BRASIL, 2004).

Os CAPS integram diversos profissionais de nível superior e médio e sua dinâmica de trabalho se realiza a partir da relação interdisciplinar dessa equipe multiprofissional. No interior do CAPS são encontrados médicos, enfermeiros, psicólogos, assistentes sociais, terapeutas ocupacionais, pedagogos, professores de educação física e qualquer outro profissional que atenda às necessidades do projeto terapêutico (BRASIL, 2004). A organização interna e a dinâmica de trabalho variam em cada CAPS. Em suma, os CAPS organizam-se em oficinas temáticas explorando a especificidade de cada um de seus profissionais, fato que nos levou a problematizar quais os reais alcances do trabalho que se pretende interdisciplinar, mas se apresenta em meio à especialização profissional no cuidado ao usuário.

Anteriormente mencionado, nossa pesquisa se efetivou em duas unidades de CAPS $^{22}$ em cidades distintas. O primeiro CAPS investigado, doravante identificado como CAPS "A", se constitui como um CAPS II, isso significa que ele deve estar num território que abrange uma população de 100 mil habitantes (BRASIL, 2012). Trata-se de instituição que orienta seus serviços para a

\footnotetext{
${ }^{21}$ Os distritos sanitários são organizações territoriais que integram o sistema de saúde de uma cidade e tem como objetivo a execução das políticas de saúde observando os contextos específicos da região.

${ }^{22}$ No sentido de atender orientações do comitê de ética em saúde, omitimos o nome e a localização dos CAPS que perfizeram esta investigação. Vale dizer que as pesquisas realizadas no Programa de Pós-graduação em Educação da UnB não têm como requisito à submissão de projetos de pesquisa em Comitê de Ética.
} 
assistência circunscrita aos indivíduos que apresentam transtornos mentais ${ }^{23}$. O bairro em que está localizado este CAPS faz parte da periferia e se instala, em certa medida, numa comunidade de baixa renda. Sua infraestrutura no ponto de vista quantitativo é boa, embora haja traços de sucateamento em face às dificuldades de investimento público na manutenção do espaço. De todo modo, são três casas amplas num lote de aproximadamente $1500 \mathrm{~m}^{2}$. As casas oferecem salas para terapias individuais e em grupo, salas de reuniões para os profissionais, copa e cozinha, e ainda um espaço de convivência com televisão, som e computador. Com relação aos recursos humanos, possui médicopsiquiátrica, clínico geral, psicólogos, assistentes sociais, enfermeiros, professores de educação física, arte terapeuta e terapeuta ocupacional. Além disso, possui equipe técnica administrativa, serviço de limpeza e segurança. $O$ território onde se localiza este CAPS não possui grande densidade demográfica, fato que contribui para que a equipe e o espaço comportem a demanda que solicita o serviço.

O segundo CAPS, identificado a partir de agora como CAPS "B", também se constitui como um CAPS II e é específico para assistência em transtornos mentais. Diferentemente do CAPS "A", está localizado numa região de grande concentração demográfica. Observa-se, nesse sentido, que sua capacidade é bastante pressionada em função da alta demanda. Além disso, a unidade federativa deste CAPS possui uma das piores coberturas de serviço em saúde mental do país em números proporcionais (BRASIL, 2012), algo que fica bastante evidente quando se percorre este CAPS e se constata a quantidade de pessoas procurando atendimento cotidianamente. Sua infraestrutura possui características correlatas às orientações de constituição de um CAPS. Este CAPS se localiza numa região residencial. Trata-se de um sobrado, que conta com salas de atendimento de grupo e também individual e possui um espaço administrativo e uma cozinha. O quintal serve como espaço de convivência e também é palco para algumas oficinas. A varanda da frente possui sofás e alguns assentos, onde as

\footnotetext{
${ }^{23}$ Existem outros modelos de CAPS que são constituídos especificamente para o atendimento de problemas psicossociais deflagrados por álcool e drogas e para assistência exclusiva de crianças e adolescentes.
} 
pessoas são acolhidas. Comparado ao CAPS "A", trata-se de um espaço pequeno, mas que opera com uma quantidade maior de usuários. O conjunto de profissionais é formado por médico-psiquiatra, clínico geral, psicólogos, assistentes sociais, terapeutas ocupacionais e enfermeiros. Possui também técnicos de enfermagem que contribuem tanto em tarefas administrativas quanto terapêuticas. Existe uma quantidade grande de estagiários e voluntários que contribuem com o serviço.

\section{Instrumentos de pesquisa}

A pesquisa que se estrutura numa perspectiva qualitativa reclama uma compreensão distinta das metodologias inspiradas no modelo positivista de produção do conhecimento. No que diz respeito à lógica de produção da informação, a Epistemologia Qualitativa procura romper com a ideia do pesquisador que coleta dados e o faz de forma neutra ao fenômeno da investigação. Em nossa perspectiva metodológica, a ruptura se concretizou na forma de preceder frente aos instrumentos de pesquisa. Estes passam a ter um caráter facilitador para se pensar e produzir uma informação, no qual o pesquisador é sempre o sujeito ativo desse processo. Na medida em que o estudo da subjetividade no que diz respeito à produção de sentidos subjetivos não se dá por uma via consciente (GONZÁLEZ REY, 2005a; 2012a), podemos compreender, assim, que a informação não é revelada pelo instrumento. $O$ instrumento facilita a produção de indicadores, que por sua vez, são fundamentais para o processo construtivo-interpretativo do conhecimento.

A escolha dos instrumentos de pesquisa deve estar associada à problemática do estudo. Entretanto, a pesquisa qualitativa não deve se estruturar de forma estática e fragmentada sob o risco de ferir suas características primordiais e que se confrontam com outros modelos pragmáticos. Observando os estudos na psicologia a partir de uma tradição empirista e positivista, González 
Rey (2005b, p.77) alerta que "o uso de instrumentos se converteu em um fim em si mesmo dada a capacidade atribuída a eles para produzir resultados 'finais', suscetíveis de serem utilizados como entidades objetivas no processo estatístico de análise". Portanto, os instrumentos jamais podem subsumir a capacidade criativa e reflexiva do pesquisador, sobre isso alerta González Rey (2005d, p.38):

\begin{abstract}
A premissa de que o valor da informação está definido pelo caráter dos instrumentos que a produzem exclui o momento de aplicação das idéias e reflexões do pesquisador; considerando só a informação procedente dos instrumentos como legítima, com a qual a coleta de informação se converte em um ritual instrumental que exclui toda a informação proveniente da reflexão do pesquisador. Dessa maneira, as diferenças criativas dos pesquisadores são subordinadas a diretrizes padronizadas para qualquer operação metodológica; essas diretrizes devem reportar dados comparáveis entre si, cujas fontes são os instrumentos com suas respectivas exigências despersonalizadas que os legitimam, os experimentos capazes de resultados não discutíveis, ou as situações de observação mediadas pelo uso de juízes que suprimem qualquer informação não apoiada pelo consenso. Essa forma de utilizar o critério de juízes nas diversas operações metodológicas omite a singularidade dos pesquisadores e subordina o criativo e o intelectual ao puramente operacional.
\end{abstract}

A admissão da Teoria da Subjetividade anunciada como esteio do presente estudo impõe outro olhar metodológico que precisa buscar alternativas instrumentais para perceber o fenômeno em sua complexidade.

Nesse sentido, procuramos nos orientar por instrumentos que oportunizaram a máxima dinâmica interativa entre pesquisador e sujeito colaboradores da pesquisa. Com efeito, fez-se uso excessivo de dinâmicas de diálogo que se constituíram num contexto formal ou informal. "O caráter dialógico da pesquisa permite que os participantes participem dela a partir de suas inquietações, suas memórias e seus problemas atuais, o que é fundamental para o seu envolvimento nesse processo" (GONZÁLEZ REY, 2011, p.50). Logo, as configurações subjetivas vão se constituir em meio às falas e a todos as formas de expressão que os instrumentos devem propiciar. Estas, por sua vez, se articulam às hipóteses e ao pensamento reflexivo do pesquisador, numa dinâmica recursiva, alimentada ainda por outros momentos vividos in loco no cenário de 
pesquisa. Outrossim, acentua-se o caráter construtivo-interpretativo da construção da informação.

A seguir, destacamos a dimensão teórica dos instrumentos que foram utilizados à luz da Epistemologia Qualitativa bem como as características específicas destes instrumentos em nossa pesquisa.

\section{Dinâmicas conversacionais}

"A ruptura com a epistemologia estímulo-resposta faz com que reivindiquemos em nossa metodologia os sistemas conversacionais, os quais permitem ao pesquisador deslocar-se do lugar central das perguntas para integrar-se em uma dinâmica de conversação [...] que implique, com naturalidade e espontaneidade, os participantes" (GONZÁLEZ REY, 2005d, p.45). Isso quer dizer que as informações extraídas de diálogos com os sujeitos não necessariamente precisam se vincular a uma taxonomia de categorias e perguntas pré-estabelecidas que determine e impõe assuntos do tema a ser investigado. Por isso, nada está definido a priori, "pois cada novo momento do processo pode representar uma diferente etapa de sentido subjetivo dos participantes", que por sua vez, solicita ao pesquisador uma exploração desse momento de forma criativa, mantendo-se atuante durante esse decurso. Assim, entendemos que a "conversação" deve se pautar sempre em ser um processo ativo, no qual a interlocução entre pesquisador e sujeitos aconteça de maneira espontânea e implicada ao que se pretende investigar. Esse processo ocorre durante os inúmeros contatos e momentos no qual o pesquisador se relaciona afetivo-emocionalmente aos sujeitos. Só assim é possível preservar uma dinâmica interativa ao diálogo, elemento muito caro a nossa perspectiva metodológica.

\subsection{Participação em reuniões multiprofissionais}

Durante nosso percurso na pesquisa, estivemos sempre que possível integrados à dinâmica de trabalho dos CAPS. Nosso objetivo era experimentar tal dinâmica com a máxima aproximação ao cotidiano laboral dos profissionais e, em especial, ao da educação física. Logo, sensibilizamos a gerência do CAPS no 
sentido de poder frequentar e, na medida do possível, participar ativamente das reuniões que organizam o trabalho coletivo da instituição. Tanto no CAPS "A" como no CAPS "B" haviam reuniões coletivas de todos os profissionais em um período e dia específico. No CAPS "A" participamos com bastante frequência destes encontros e tomamos os debates que aconteciam nestes momentos como parte importante da produção de informação para o nosso estudo. Percebíamos que participar das reuniões, observada já a nossa aceitação como pesquisadores naquela instituição, determinava em grande medida estar em meio a produção de sentidos subjetivos que se expressam quando aquele conjunto de profissionais discutem temas pertinentes ao trabalho e, sobretudo, os problemas que atravessam e implicam decisões coletivas, mas que nem sempre são consensuais. Nessas reuniões se configuravam aspectos da subjetividade social do CAPS que dificilmente se percebe caso não haja uma participação integrada a este momento do trabalho, pois são nas reuniões de equipe que muitas das decisões, que operacionaliza o CAPS, são tomadas. Vale dizer que no CAPS "B" nós participamos muito pouco destes momentos devido a incompatibilidade de agenda da pesquisa em se alinhar com as reuniões de equipe desse CAPS.

\subsection{Roda de debate nas oficinas}

A presença do professor de educação física ou mesmo a natureza do trabalho em oficinas orientam o trabalho numa forma pedagógica de se relacionar com os usuários. As oficinas, que não são exclusivas do trabalho da educação física, são realizadas com um grupo de usuários que aceitaram em participar dela com o objetivo de ver na oficina uma parte importante de seu projeto terapêutico. Os profissionais de saúde, responsáveis pela oficina promovem uma mediação com os usuários de forma bastante diversa. No entanto, o caso específico da educação física, e isso se mostrou bastante evidente no CAPS "A", existe uma forma de desenvolvimento do trabalho no qual a relação com os usuários inclui uma rotina que, parecia ter muito a ver com a dimensão pedagógica da formação acadêmica dessa área. A oficina promovida pelo professor de educação física incluía sempre em seu desenvolvimento a formação de uma roda com os usuários com o objetivo de apresentar a proposta de atividade daquele dia e, ao final das 
atividades, formava-se uma nova roda para debater aquilo que foi vivido $e$ encaminhar novas propostas. Percebíamos nestes momentos, em função da potencialidade da dinâmica de debate, algo bastante proveitoso no sentido de produzir informações. Assim, tomamos essa "estratégia pedagógica" de organização dos discursos de quem participa, como um instrumento para pensar a produção de sentidos subjetivos dos sujeitos colaboradores da pesquisa. No CAPS "B", embora este formato não estivesse presente, aos poucos fomos auxiliando a responsável pela oficina de futebol a implementar este momento. Fato que, mais tarde, acabou sendo incorporado totalmente à rotina de trabalho desta oficina. Vale dizer que a criação deste momento foi fundamental para a produção de informação que procurava tornar protagonista os usuários em torno das configurações subjetivas da atuação da educação física e o uso de práticas corporais como meio terapêutico.

\subsection{Momentos informais de interação}

Para além das situações que estávamos presentes e integrados à dinâmica de trabalho do CAPS e que se se constituíram como momentos empíricos valiosos para a construção da informação, houve também outras oportunidades para produzir informação que tinham um caráter aleatório, espontâneo e imprevisível na vivência de diálogos com os sujeitos. Trata-se de momentos de interação com os sujeitos colaboradores da pesquisa e que, exatamente em face a este caráter espontâneo, jamais podem ser desprezados enquanto formas de expressão de subjetividade individual dos sujeitos. Assim, sempre que possível procuramos estabelecer laços de afetividade e envolvimento emocional com os colaboradores da pesquisa. Isso obviamente não ocorre exclusivamente naqueles espaços formais e institucionais do trabalho em saúde mental. Neste caso, aconteciam entre as atividades, citadas aqui as conversas nos espaços de convivência ou no lanche após as oficinas no CAPS "B", por exemplo. Ainda tinham os eventos que o CAPS realizava como a festa junina e outras atividades como o bazar no CAPS "A" que acontecia na última quinta-feira no mês e sempre mobilizava as pessoas para um espaço que oferecesse música e dança. Enfim, 
são cenas sociais que espelham o cotidiano concreto dos sujeitos e que, em nossa perspectiva teórico-metodológica não podem ser desprezadas.

\section{Uso de indutores não-escritos}

"Os indutores que podem estar na base de qualquer instrumento são parte do infinito repertório de operações simbólicas das pessoas em seus contextos culturais que se convertem em instrumentos [...] com vistas à produção de conhecimento" (GONZÁLEZ REY, 2005d, p.65). O uso de indutores não escritos tem sido aplicado às pesquisas sociais de maneira corrente por meio de cartas, filmes, fotos, pranchas, etc. Seu objetivo é o de facilitar as expressões de informação que envolve a produção de sentido. Na Epistemologia Qualitativa é possível recorrer a esta categoria de instrumentos quando se busca, de forma criativa, avançar sobre um espaço de produção de sentidos em conformidade ao contexto simbólico dos sujeitos da investigação. Por exemplo, "o uso de fantoches é uma via privilegiada na pesquisa com crianças, pois cria uma atmosfera lúdica na qual a criança se expressa com total espontaneidade" (GONZÁLEZ REY, 2005d, p.69). Com efeito, o fundamental é explorar níveis cada vez mais contundentes de envolvimento emocional dos sujeitos em interação subjetiva constante com os pesquisadores.

\subsection{Jogando com os usuários na oficinal de futebol}

Especificamente no CAPS "B" nossa aproximação permeou um contato muito maior com os usuários atendidos. Ali, nos juntamos a uma técnica em enfermagem que contribuía para a assistência, promovendo uma oficina de futebol. Embora fosse uma oficina não obrigatória, percebemos que nela havia uma procura bastante grande de usuários. As experiências da oficina eram objeto de diálogo entre os demais profissionais do CAPS e, sobretudo, da gerência, que precisou pleitear junto à administração pública, em espaço para esta oficina, uma vez que o CAPS não dispunha dele. Assim, um horário de uma quadra poliesportiva pública localizada nos arredores do CAPS foi reservada pela administração regional para que fosse possível realizá-la. A oficina de futebol já 
tem quase dois anos e acontece nas quintas-feiras pela manhã, das $9 \mathrm{~h}$ às $10 \mathrm{~h} 15$. Além de reunir usuários de diversos tipos de diagnóstico, não exclui sujeitos em função de seu transtorno. Inscritos e frequentando periodicamente contam-se 21 usuários, dos quais apenas um é mulher. Em função da temática e de nossos interesses de pesquisa, vimos nesta oficina uma oportunidade de produção de informação. Nossa participação na oficina, inicialmente, era o de auxiliar na realização dela à luz da educação física. Entretanto, ao longo do processo, percebemos o quão seria interessante se passássemos a também participar junto com os usuários e jogar futebol com eles. Desde nossa chegada, percebíamos um clima de empatia e um convite para jogar já havia sido feito por eles. Ao aceitar o convite, compreendemos que o "jogar junto" abria a possibilidade de se compreender um conjunto de expressões de corpo que o distanciamento não permitiria. O jogo cria um ambiente de conflito, de exposição de corpo (se joga bem ou se joga mal) e tensão emocional que, para nós, precisava ser explorado como instrumento capaz de produzir informação.

\section{Investigando singularidades: os sujeitos colaboradores da pesquisa}

Ao longo da pesquisa, não houve uma preocupação em determinar uma quantidade fixa de sujeitos que eventualmente poderiam ter participado de nosso estudo. Sobre isso, vale dizer que no debate acadêmico sobre as pesquisas qualitativas é possível perceber uma orientação de pesquisa que identifica de forma apriorística o quantitativo de participantes, sejam de grupos grandes, pequenos ou mesmo de estudos de caso. Essa determinação desvirtua o valor epistemológico da pesquisa qualitativa já que "não é o tamanho do grupo que define os procedimentos de construção do conhecimento, mas sim as exigências de informação quanto ao modelo em construção que caracteriza a pesquisa" (GONZÁLEZ REY, 2005d, p.110). Sobre isso, a Epistemologia Qualitativa assim recomenda: 
O pesquisador qualitativo define os grupos em função das necessidades que vão aparecendo no transcorrer da pesquisa, e a primeira atitude a ser tomada antes de selecionar alguém é envolver-se no campo para observar, conversar e conhecer, de forma geral, as peculiaridades do contexto em que a pesquisa será desenvolvida: a seleção do grupo vai envolver hipóteses feitas pelo pesquisador. Posteriormente e conhecendo os aspectos da organização e do funcionamento do espaço social a ser estudado, o pesquisador passará a participar de diferentes atividades organizadas dentro de tal espaço. Nesse trânsito pelo campo, aparecerão as primeiras hipóteses a serem organizadas em conceitos e reflexões que servirão de base para o modelo condutor do processo de construção. (GONZÁLEZ REY, 2005d, p.110).

Imbuídos dessa perspectiva, elegemos alguns sujeitos que foram, de fato, verdadeiros colaboradores da pesquisa. Em que pese as considerações críticas que emergiram em nosso modelo teórico, muitas de nossas provisórias conclusões foram necessariamente a pauta de diálogos com estes sujeitos, a fim de preservar nele a condição de ser sujeito, que é a de se manter ativo frente ao processo de diálogo ou qualquer outra forma de expressão. Do contrário, eles seriam apenas um "conjunto de nossa amostra". De todo modo, é necessário preservar a identidade deles como um aspecto ético incontestável. Com este objetivo, além de preservar seus nomes, os apresentamos a partir das informações genéricas abaixo.

\section{CAPS "A"}

\begin{tabular}{|c|c|c|c|c|c|}
\hline $\begin{array}{c}\text { Sujeito } \\
\text { colaborador }\end{array}$ & Sexo & Idade & $\begin{array}{c}\text { Grau de } \\
\text { escolaridade }\end{array}$ & Profissão & $\begin{array}{c}\text { Tempo de } \\
\text { experiência } \\
\text { no CAPS }\end{array}$ \\
\hline J.M & $\mathrm{M}$ & 31 & Superior & $\begin{array}{c}\text { Professor } \\
\text { de } \\
\text { Educação } \\
\text { Física }\end{array}$ & 2 anos \\
\hline
\end{tabular}




\begin{tabular}{|c|c|c|c|c|c|}
\hline R.L. & F & 42 & $\begin{array}{c}\text { Superior } \\
\text { Pós-graduada }\end{array}$ & Psicóloga & 5 anos \\
\hline M.C. & F & 49 & $\begin{array}{c}\text { Superior } \\
\text { Pós-graduada }\end{array}$ & Psicóloga & 5 anos \\
\hline
\end{tabular}

CAPS "B"

\begin{tabular}{|c|c|c|c|c|c|}
\hline $\begin{array}{c}\text { Sujeito } \\
\text { colaborador }\end{array}$ & Sexo & Idade & $\begin{array}{c}\text { Grau de } \\
\text { escolaridade }\end{array}$ & Profissão & $\begin{array}{c}\text { Tempo de } \\
\text { permanência } \\
\text { no CAPS }\end{array}$ \\
\hline E.A. & $\mathrm{M}$ & 38 & $\begin{array}{c}\text { Ensino Médio } \\
\text { completo }\end{array}$ & Bancário & 4 anos \\
\hline B.L. & $\mathrm{M}$ & 20 & $\begin{array}{c}\text { Ensino Médio } \\
\text { incompleto }\end{array}$ & Não tem & 1 ano \\
\hline M.D. & $\mathrm{M}$ & 46 & $\begin{array}{c}\text { Ensino Médio } \\
\text { completo }\end{array}$ & Pedreiro & 3 anos \\
\hline
\end{tabular}

\section{Apontamentos metodológicos sobre a organização da informação}

O conjunto de informações produzidos com base na Epistemologia Qualitativa, não segue o padrão de organização comum em outras abordagens metodológicas de produção de conhecimento. Nesse sentido, em nossa perspectiva teórica não se opera a prática do "tratamento dos dados" e da imposição de recursos técnicos que orientam sua análise. Assim, não existem etapas que identificam o percurso da investigação como primeiro a coleta de dados, na sequência a organização e a análise de dados, para finalmente se elaborar o relatório de pesquisa, que pode ser um artigo, uma dissertação ou uma tese. 
$\mathrm{Na}$ esteira dessa compreensão, elaboramos algumas estratégias de organização da informação. Para isso, foi fundamental não perder de vista que as informações fornecem aspectos importantes para a elaboração de um modelo de inteligibilidade que se integra de forma inseparável ao sentido subjetivo que o pesquisador oferece quando de sua produção teórica final (GONZÁLEZ REY, 2005b). Ademais, o panorama da produção de conhecimento no tocante à pesquisa qualitativa defendida por González Rey (2005b) sugere uma menor preocupação com o acúmulo de dados pragmáticos, e muito mais com um recrudescimento em torno da produção de ideias e explicações dos indicadores que emergiram no curso da pesquisa.

Destarte, as experiências vividas em diálogos e outras expressões com os sujeitos são registradas em diário de campo. Observa-se, entretanto, que tais registros não se constituem como mera descrição do vivido. Ao contrário, o diário de campo é a rica fonte de elaboração da construção de informação sendo mister que seja uma composição que se funda na produção de sentido subjetivo e que o pesquisador possa, de antemão, discutir reflexivamente as informações, pontuando as suas elaborações sem prescindir do teórico. Dessa forma, o diário de campo se integra ao capítulo de construção da informação, no qual o pesquisador passa a refletir as informações produzidas pelo momento empírico à luz de seus referenciais teóricos. Na prática, a construção da informação se processa, em grande medida, concomitantemente ao momento empírico. A continuidade do momento empírico em meio à produção de informação e a elaboração do modelo teórico desta tese se tornou a tensão necessária para reconfigurar apropriações teóricas e assim, ampliar a possibilidade de elaboração de novas zonas de sentido em face aos nossos objetivos de pesquisa. 


\section{IV - CONSTRUÇÃO DA INFORMAÇÃO}

Sonhar o sonho impossível, Sofrer a angústia implacável, Pisar onde os bravos não ousam,

Reparar o mal irreparável, Amar um amor casto à distância,

Enfrentar o inimigo invencível, Tentar quando as forças se esvaem, Alcançar a estrela inatingível: Essa é a minha busca. Dom Quixote, de Cervantes.

- Onde está seu sofrimento quando você joga futebol? Pergunta de um usuário de CAPS para outro usuário, após uma prática de futebol 


\section{Considerações iniciais sobre a construção da informação}

Este capítulo tem como objetivo apresentar um conjunto de reflexões construídas ao longo do processo de investigação e tiveram, sobretudo no momento empírico, seus determinantes principais.

Vale dizer que os apontamentos abordam tópicos que subjazem a produção construtivo-interpretativa de informações e que González Rey (2005c) denomina de lógica configuracional. Trata-se da tensão estabelecida pelo pensamento teórico do pesquisador em confronto com a cena empírica e se dá no processo de ação da investigação. Do ponto de vista das elaborações destacadas a seguir, objetiva-se submeter à reflexão temas que não têm recebido atenção no campo da saúde em sua interface com a educação física, mas que emergiram como configurações subjetivas da atuação da educação física na saúde mental.

Atravessam este momento teórico aspectos relacionados ao universo da saúde pública brasileira, em especial a saúde mental. O trabalho da educação física nos espaços da saúde mental do setor público, no caso, os Centros de Atenção Psicossocial (CAPS), torna-se protagonista na medida em que a produção de informação esteve sempre atrelada a atuação educativa da educação física neste espaço e que foi alvo de toda dimensão empírica da pesquisa. As reflexões teóricas foram produzidas com base na teoria da subjetividade numa perspectiva cultural-histórica.

Procuramos, assim, elaborar um modelo teórico que permita dar visibilidade e valor heurístico ante alguns temas organizados em eixos temáticos. Inspirados em Goulart (2013), estruturamos as discussões deste capítulo por meio de dois eixos temáticos. O primeiro intitula-se "Configurações subjetivas da atuação da educação física em CAPS: dilemas e desafios" produzidos com base na cena empírica do CAPS "A". Subcapítulos são organizados procurando delimitar assuntos que vão se desdobrando no interior deste mesmo eixo temático. Isso ocorre também com a organização do segundo eixo temático, intitulado "Configurações subjetivas da prática da educação física em CAPS: produção de sentido em quem vive às práticas corporais" produzido com base no momento empírico vivido no CAPS "B". 
Neste capítulo que a aborda a construção da informação é importante destacar duas categorias da Epistemologia Qualitativa ainda não apresentadas, mas que neste momento se tornam fundamentais para o desenvolvimento do estudo. Tratam-se das categorias de indicador e de zona de sentido. A primeira tem a ver com o conjunto de significados gerados pela construção do pesquisador ante os aspectos que se relacionam aos diversos instrumentos ou situações vividas no momento empírico. Os indicadores são fundamentais porque é por meio deles que estrutura-se as hipóteses e o esforço do pesquisador em gerar inteligibilidade sobre determinado assunto, o que se dá no processo de construção da informação (GONZÁLEZ REY, 2005d). Uma característica importante do indicador é que ele não representa um elemento descritivo. $O$ trecho de uma fala num momento de conversação, por exemplo, pode gerar um indicador não pelo conteúdo da fala em si, mas sobre o que os desdobramentos e a expressão da fala pode significar em torno da produção de sentido subjetivo. Assim, o indicador é uma construção teórica do pesquisador. A segunda categoria, as zonas de sentido, González Rey (1997) compreende o valor heurístico de um saber e que desenvolve uma nova zona de inteligibilidade diante de um conceito que antes já era utilizado em determinado contexto, por um autor específico ou por uma corrente de pensamento científico, mas que em função da elaboração teórica do pesquisador, se modifica em face ao estabelecimento de uma nova forma de olhar tal conceito. 


\section{CONFIGURAÇÕES SUBJETIVAS DA ATUAÇÃO DA EDUCAÇÃO FÍSICA EM CAPS: DILEMAS E DESAFIOS}

Como foi dito acima, desenvolvemos e organizamos a construção da informação em dois eixos temáticos. A seguir, abordaremos o primeiro eixo construído com base na cena empírica do CAPS "A". O principal objetivo é refletir sobre as configurações subjetivas da atuação do professor de educação física que está presente, trabalhando efetivamente integrado a uma equipe multidisciplinar do CAPS. Tal objetivo nos oferece desdobramentos importantes para avançar em nosso modelo teórico e gerar inteligibilidade ante um fenômeno pouco explorado na educação física. Assim, algumas zonas de sentido vão se configurando em meio à tessitura do texto, no qual foi possível discorrer sobre aspectos que atravessam o trabalho da educação física na saúde mental.

Ao pensarmos estes aspectos à luz da teoria da subjetividade de González Rey, associada a uma perspectiva epistemológica e de intervenção da educação física na saúde pública a partir da saúde coletiva compreendemos que o contexto da saúde mental encerra uma complexidade que faz surgir para o profissional de educação física que trabalha em CAPS alguns dilemas e desafios que sua formação imediata não pressupõe. Logo, desenvolvemos ideias de que a centralidade do professor no processo educativo da intervenção em educação física com os usuários do CAPS é algo a ser questionado. Da mesma forma que o uso instrumental dos conhecimentos do saber escolarizado da educação física possui inúmeras dificuldades se caso haja transposição da experiência de formação e trabalho da educação física escolar para a cena da saúde mental. Ademais, a inserção da educação física em meio a uma equipe multiprofissional tem sido um desafio em torno da legitimidade social e científica desta nova área para a assistência pública em saúde mental. As formas de submissão da educação física ante a ordem e a lógica medicalocêntrica, ainda muito presente no CAPS, demonstra uma contradição em face ao papel social e ao alcance potencial da educação física para uma perspectiva de promoção da saúde.

Estes aspectos levantados são melhor discutidos e destrinchados ao longo desta seção e primeiro eixo temático. A Epistemologia Qualitativa, suporte epistemológico e metodológico desta investigação, propiciou nossas reflexões 
teóricas e a abertura de discussões não presentes na educação física quando submetida ao contexto da saúde pública, mais especificamente da saúde mental.

Ao final desta seção, encaminhamos algumas provisórias conclusões com o objetivo de sintetizar aquilo que foi antes abordado e, ao mesmo tempo, encaminhar novas questões que ampliem o debate e que seja alvo de novos estudos.

\section{A emergência da educação física como área de conhecimento e intervenção em saúde mental: contradições e possibilidades}

O CAPS é um espaço acolhedor para a educação física. A perspectiva do trabalho multiprofissional é um facilitador da criação de um ambiente que almeja diversificar ações laborais no sentido de promover um cuidado bastante próximo dos usuários do serviço e que seja atraente a eles. Nesse sentido, as práticas corporais parecem ser uma forma interessante de acessar os sujeitos que chegam ao CAPS com severos transtornos psíquicos. Se por um lado a saúde mental é um espaço bastante novo de intervenção da educação física e facultativo a um projeto de CAPS, por outro, a aceitação da parte dos demais profissionais envolvidos e dos usuários beira ao consenso.

J.M., professor de educação física de 31 anos que possui 2 anos dedicados ao CAPS "A" lembra que desde o início de sua chegada se sente reconhecido e respeitado pelos colegas de trabalho:

"Todos gostaram da ideia de ter a educação física representada no trabalho do CAPS. Quando cheguei, muitos vieram falar comigo sobre a expectativa dos usuários de ter alguém que pudesse realizar com eles atividade física. Os colegas da psicologia achavam que oficinas práticas poderiam ajudar no tratamento terapêutico e atividade física poderia ajudar os pacientes a melhorar sua forma física já que alguns tinham distúrbios metabólicos em função dos medicamentos. 
Isso aumentava o peso deles e muitos passavam a ter seu corpo completamente transformado por conta do tratamento com remédios".

Há nesse trecho de conversação elementos que representam questões que vão além de uma boa recepção da educação física no trabalho do CAPS "A". De fato, tal trecho e um conjunto de outras informações tomadas junto aos demais profissionais desta instituição demonstram um anseio de a educação física fazer parte do trabalho. Entretanto, a partir dele é possível avançar em informações que conduzem a outros pontos que, de forma imediata quando do momento da fala de J.M., não se situava como foco de seu pensamento, mas que indica uma produção de sentido subjetivo que expressa uma compreensão de "que tipo" de trabalho se espera da educação física e para atender "quais objetivos"? Essas questões abrem uma zona de sentido que envolve a preocupação de como produzir as intervenções em educação física na saúde mental. Um desafio que não só se dá em função do recente espaço profissional criado para a área no Brasil, como se amplia ante a própria história que a educação física possui na relação com o campo da saúde.

A expectativa dos profissionais, lembrada por J.M., sinaliza por uma compreensão de uma educação física que se mostra hegemônica no imaginário coletivo das pessoas, no qual sua presença se justifica em face à ideia funcionalista de que caberia a ela proceder ante os problemas de natureza orgânica dos sujeitos. Ou seja, emagrecer os usuários parece dar o tom positivo da intervenção da educação física na saúde mental. Trata-se de clara visão reducionista forjada pelo senso comum ou pela perspectiva acrítica e biologicista da área.

É evidente que o problema do uso de psicotrópicos trazem efeitos colaterais orgânicos ao indivíduo, que poderia até ser o de obesidade. Entretanto, externalizar o problema - ou a solução (para educação física) - demonstra uma tendência a retirar de cena a produção de sentidos subjetivos dos sujeitos que fazem uso de medicamentos ou de como eles se relacionam com a possibilidade de praticar atividade física. Como lembra González Rey (2011, p.71), “(...) as doenças nunca anulam a produção de saúde, o que implicaria a morte da 
pessoa". Corroborando a esse pensamento, poder-se-ia dizer que atividade física por si só não determina uma condição de saúde, o que implicaria que todo praticante de atividade física fosse uma pessoa "saudável". Isso anularia a ideia de promoção da saúde como um processo de configuração subjetiva que integra a subjetividade individual do sujeito ao contexto sócio-histórico vivido.

Em nossa opinião, isso em parte, incorpora ao debate da educação física novas zonas de sentido para a questão dos intervenientes do trabalho da biodinâmica, tão presentes na formação inicial da educação física, e os componentes sociopedagógicos, que se preocupam com os sujeitos da prática da educação física numa perspectiva "integral" ${ }^{24}$ de ser humano. Para além do que representa o debate na educação física, às vezes orientado nos termos de discursos maniqueístas, a saúde mental revela um cenário importante no que corresponde à integração destas duas correntes. Um movimento que poderia agregar preocupações da ordem da biodinâmica da educação física em meio as sociopedagógicas. A despeito dessa disputa, algo ainda não instalado nesse debate é a importância da subjetividade como uma instância ontológica no processo que orienta o trabalho da educação física, pois independente do contexto, a educação física se encarrega de uma prática "com" sujeitos ou "para" sujeitos, o que significa levar em consideração os sentidos subjetivos dos sujeitos a quem são ofertados a prática da educação física.

Ao debater a visão dos profissionais do CAPS "A" com J.M. sobre como se constituía o trabalho da educação física inserida na instituição e diante da perspectiva interdisciplinar do serviço, ele confessa:

"Posso fazer o que eu quiser nas minhas oficinas. Tenho muita autonomia. Geralmente são encaminhados para mim os usuários que já gostam de atividade física e que por conta dos problemas que estão enfrentando acabam se tornando

\footnotetext{
${ }^{24}$ Importante colocar entre as aspas a ideia de ser humano integral no campo acadêmico da educação física, já que a integralidade na área opera marcadamente pela lógica racionalista de uma integração social exclusivamente. Embora seja um avanço quando comparada a lógica exclusiva do trabalho com a perspectiva biológica de corpo, ainda pouco se sente uma preocupação com uma integralidade que se ocupe em enfatizar a importância da subjetividade como expressão emocional do sujeito e que contemple a história e a cultural como instâncias articuladoras dessa subjetividade.
} 
sedentários. Sempre converso com as psicólogas e percebo que os usuários gostam muito das minhas oficinas pois elas têm uma dinâmica de prática. No fundo, eles (os usuários) já estão cansados de ficar conversando ou ouvindo alguém falar algo para eles".

Particularmente este trecho traz alguns indicadores que se relacionam às formas que J.M. e os profissionais do CAPS "A" compreendem a atuação profissional e os usuários do serviço. Nosso objetivo quando propúnhamos a dialogar com J.M., neste momento específico, era o de compreender melhor o desafio de se trabalhar na perspectiva interdisciplinar, um dos princípios do trabalho em CAPS. No entanto, J.M. desdobra aspectos que orientam a percepção para uma configuração subjetiva do trabalho (e da atuação da educação física) que não podemos deixar de refletir. Vale dizer, que o sentido subjetivo não emerge de forma direta e linear em meio ao discurso, por isso esse trecho de nossas conversas com J.M. se tornou relevante.

J.M. compreende sua possibilidade de livre trabalho e escolhas sobre as oficinas como uma forma de autonomia. Sua expressão, ao falar isso, nos demonstrou satisfação em viver esse ambiente no trabalho. Entretanto, a "autonomia" observada e comemorada por J.M., sinaliza uma contradição ante os anseios institucionais no que diz respeito ao trabalho coletivo e ao desafio da interdisciplinaridade da assistência. Até que ponto "poder fazer o que se quer" representa de fato autonomia? A ideia de autonomia de J.M. sugere que as regras do trabalho em "sua" oficina sejam convencionadas de maneira ensimesmadas, em nossa opinião, deturpando o lugar da produção de um trabalho, que embora ofereça um espaço específico à educação física, necessita gerar possibilidades de práticas que dialoguem com outros conhecimentos na constituição destas práticas. Além disso, vale refletir sobre a estratégia da oficina como espaço terapêutico. A história de J.M. antes de se estabelecer no CAPS é de uma formação centrada em aspectos pedagógicos e de trabalho em escola. Em que pese tal formação contribuir enormemente no conjunto de ações educativas que acompanhamos durante a realização de seu trabalho nas oficinas e que mais à frente iremos debater, nesse caso específico sobre as formas de constituir seu 
trabalho "autônomo", em nossa opinião, acaba isolando a educação física das demais áreas do CAPS. J.M. parece carregar uma configuração de uma subjetividade social da atividade docente na escola no qual a sala de aula é um espaço que pertence ao professor, que o domina e o explora como quer.

Acompanhando as oficinas dinamizadas por J.M. percebemos que os usuários também pouco estabelecem um diálogo mais protagonista em relação às possibilidades de viver as práticas corporais em função de seus desejos. Há uma certa passividade da parte dos usuários que geralmente tem uma postura muito próxima a outros contextos de atuação da educação física, sobretudo a escolar. Os usuários esperam que J.M. ofereça as práticas, tanto no que diz respeito à natureza dessas práticas e quais seriam elas, até as formas de vivenciá-las. Ou seja, o professor de educação física centraliza todo o processo e os usuários executam as atividades em torno das práticas corporais, sejam elas caminhadas, alongamentos, exercícios de ginástica, jogos e brincadeiras e alguns esportes, como futebol e voleibol. Recuperando o nosso indicador, J.M. expõe que as psicólogas direcionam os usuários conforme elas percebem o desejo deles de fazer parte de uma oficina da educação física. $O$ fato dos usuários escolherem as oficinas que farão parte de seu projeto terapêutico, embora seja um avanço, não garante que eles continuem protagonistas quando vivenciam as oficinas. Para nós, seria fundamental que as escolhas do usuário, e assim, a abertura para a produção de uma configuração subjetiva que processasse o seu projeto terapêutico, fossem mantidas no interior das próprias oficinas. Isso parece não acontecer na medida em que J.M. compreende que os usuários procuram sua oficina "para deixarem de ser sedentários".

Pode até ser verdade que os usuários tenham essa compreensão, afinal de contas, é bastante interessante a forma como J.M. compreende a subjetividade individual de alguns usuários, que certamente comentam com ele que estão "cansados de ficar conversando". De fato, a educação física acaba sendo um espaço bastante distinto do trabalho das demais oficinas oferecidas por outros profissionais. Estas acabam sendo dirigidas e dinamizadas quase que exclusivamente por meio da linguagem oral. $O$ corpo é praticamente abandonado. É uma lógica de terapia do cognitivo, reduzindo completamente a condição 
complexa e de integralidade do ser humano. Talvez por isso, os profissionais, mesmo se baseando no senso comum, veem como necessária a presença da educação física no CAPS. A constituição de um espaço numa oficina que se expressa pelo corpo acaba sendo um aliado do trabalho da educação física no CAPS. Afinal de contas, é fundamental que os usuários estejam disponíveis e sintam vontade de fazer parte de uma oficina, e isso parece ser parte da expressão de subjetividade individual dos usuários que aderem às oficinas de educação física.

De todo modo, intuir que a finalidade do trabalho e atuação da educação física em CAPS é para estabelecer um espaço de prática e atividade que vise aos usuários acabar com a sua condição sedentária parece, em nossa forma de ver o problema, algo que tende para um reducionismo do papel social da educação física na saúde mental. Mesmo assim, os sentidos subjetivos produzidos por J.M. na maneira de perceber os usuários parecem ser coerentes com suas formas de atuação. A centralidade do processo de realização da oficina está todo nele, o professor. Na medida em que os usuários querem manter-se ativos, J.M. oferece isso a eles nas oficinas. Do contrário, ele promoveria outras dinâmicas, incluindo os usuários no processo de construção das práticas corporais no interior da oficina. Discutindo com J.M. a possibilidades de outras dinâmicas e também sobre se as oficinas impactavam os usuários no sentido de diminuir a condição sedentária deles, ele assim se expressa:

"Eles participam bastante das oficinas da educação física, mas eles não conseguem fazer outras atividades fora do CAPS porque muitos trabalham, ou quando não trabalham porque estão desempregados eles não têm motivação para fazer atividade física. Por isso que aqui é importante para eles este espaço. Se não fosse a educação física eles não teriam como fazer nenhuma atividade fora. Precisam de alguém que os motive porque senão tiver alguém eles não fazem. Você viu que eu estou sempre motivando eles para fazer as atividades". 
Novas contradições cercam a produção de sentido subjetivo de J.M. e outros indicadores surgem, quando se confronta a prática da educação física aos aspectos que induzem e legitimam o trabalho de agentes de saúde de outras áreas a fim de compor um quadro profissional que contribua efetivamente para uma assistência psicossocial orientada à emancipação dos sujeitos com transtornos mentais. Nesse sentido, é preciso questionar como se configura subjetivamente a participação dos usuários e se a atuação da educação física vai ao encontro dos princípios da desinstitucionalização (AMARANTE, 2009; BARROS, 1994; GOULART, 2015) dos usuários do CAPS.

A ideia de participação de usuários em uma oficina de educação física não pode ser objetivada em expressões com quais se relacionam à simples observação de que os sujeitos realizam e praticam as atividades. Se fosse somente isso, seria possível inferir que tal panorama, que nos parece comum no CAPS "A", sugere que os usuários sejam assujeitados a realizarem as atividades, algo bastante comum em outros contextos do trabalho de educação física. Ou seja, há a figura de um professor que determina em que momento se irá fazer a atividade, qual atividade será feita, com que frequência e com qual intensidade. Esse contexto tratar-se-ia do conjunto de princípios do exercício físico e do treinamento esportivo que hegemonicamente se pratica na educação física e que também se observa em outros cenários sociais, inclusive na saúde mental. Logo, em nossa opinião, a expressão do sujeito que deve se inserir no trabalho da educação física por meio das oficinas deveria orientar uma dinâmica na qual o usuário pudesse iniciar um processo educativo que o levasse a refletir sobre as necessidades e benefícios das práticas corporais de forma que estas se tornassem configurações subjetivas de um sujeito ativo e que procura repensar e agir ante uma nova possibilidade de modo de vida. Para isso, um conjunto de possibilidades deve ser ofertada e ao mesmo tempo deve se levar em consideração os desejos subjetivados na história e na cultura dos usuários.

A importância de se refletir sobre a necessidade dos usuários que participam de uma oficina terapêutica serem, de fato, sujeitos desse processo vai ao encontro do pensamento progressista da reforma psiquiátrica brasileira e todo 
um conjunto de anseios de serviços que conduzam peremptoriamente para uma abertura à desinstitucionalização. Os avanços instituídos pelas normatizações com relação aos objetivos da nova assistência terapêutica - materializado na instalação do CAPS - não são garantidoras da efetivação de tais objetivos. Corroborando, assim, com Goulart (2013b), é possível dizer que "fora dos sujeitos" não há desinstitucionalização. Nesse sentido, o estudo das configurações subjetivas dos processos de trabalho e, em nosso caso, da atuação da educação física, abre uma zona de sentido antes não explorada. A justificativa da inserção da educação física como área de conhecimento presente na saúde mental acabou criando uma perspectiva funcionalista do trabalho da educação física, entendendo que ela estaria determinada a preencher o hiato da ausência de atividades física na cultura dos usuários. Tal perspectiva possui uma contradição de fundo com o próprio princípio da desinstitucionalização ou, em termos práticos e seguindo a "cartilha" do trabalho no CAPS, a reinserção do usuário na sociedade, pois antes, ele estava apartado por sua condição de sofrimento. As configurações subjetivas da atuação de J.M. procede ao contrário, mesmo ele não tomando consciência disso e sendo, de fato, um profissional extremamente comprometido com o serviço público.

Por hipótese, entendemos que os usuários não se ocupam em ter uma vida ativa no que corresponde, nesse caso, em atravessar suas vidas com as práticas corporais, não porque "não tem ninguém os motivando" ou porque "trabalham muito", como sugere J.M.. Se fosse assim, tratar-se-ia de uma ação do sujeito em face a uma determinação de algo externo a ele. Desde nossa perspectiva teórica, nem teríamos sujeito nesta situação. Obviamente que o trabalho é um aspecto da vida das pessoas que ocupa muitas vezes uma parte importante do tempo delas. Entretanto, fosse isso verdade, os trabalhadores estariam fadados a não viver as práticas corporais como forma de lazer. Com efeito, uma questão salta-nos à vista: até que ponto a opção de viver as práticas corporais não são configuradas subjetivamente pelos sujeitos? Será que os sujeitos que possuem uma vida ativa em torno de vivências de prática corporais o fazem por uma consciência racional dos impactos do sedentarismo ou elas vivem 
cotidianamente as práticas corporais porque elas estão implicadas em suas configurações emocionais?

Responder tais questões oferecem uma construção teórica com base na teoria da subjetividade numa perspectiva cultural-histórica que nos permite contradizer J.M. e, assim, também uma concepção bastante difundida na educação física. Em nossa opinião, qualquer prática corporal, seja caminhar, correr, nadar, jogar, dançar, lutar, etc, compõe um conjunto de ações culturais humanas que se tornaram fenômenos históricos e que acompanham a sociedade. O fator preponderante para que os sujeitos incorporem ao longo de toda a sua vida tais práticas se deve a uma produção de sentidos subjetivos que determinada prática corporal está, ao nível do subjetivo, implicada na esfera emocional do sujeito. Logo, não se trata de não mais ser sedentário em função do sujeito se conscientizar que tal hábito traz riscos iminentes a saúde. Por exemplo, alguém passa a viver uma vida ativa e começa a correr e a se alimentar melhor porque passou a apresentar índices bioquímicos que poderiam trazer problemas cardíacos e o médico esclareceu para este sujeito os determinantes da cardiopatia. Um tempo depois, caso os determinantes bioquímicos da cardiopatia regredissem a índices de "normalidade", este sujeito manteria a prática da corrida em sua vida? A resposta pode ser sim ou não. Entretanto, nossa hipótese é de que este sujeito só irá permanecer correndo caso tal prática tenha passado a implicar sua vida ao nível do subjetivo. Não se trata apenas dos correspondentes aos aspectos de ordem bioquímica, pois de fato a atividade física ajudaria o indivíduo a produzir endorfina e consequentemente uma sensação física de prazer. Entretanto, se este mesmo sujeito estivesse impossibilitado de correr por conta de um problema articular no joelho, por exemplo, e tivesse que nadar, talvez ele não mantivesse o hábito. Seria necessário, assim, perceber a história desse sujeito e a sua cultura para refletir sobre os porquês de preferir correr a nadar. Todavia, o que importa para nós é refletir sobre a ideia de que a representação de um sujeito ativo e que modifica seu modo de vida implica também em transformar sua subjetividade individual diante de suas configurações subjetivas de seus hábitos de vida. Isso, certamente, pressupõe as práticas corporais. 
Com efeito, seria muito difícil os usuários da oficina de J.M. manterem-se ativos e modificar seu modo de vida em torno das práticas corporais, em função da dinâmica pedagógica que se processa na oficina e, sobretudo, ante a configuração subjetiva de atuação do professor. A não implicação emocional dos sujeitos diante das práticas corporais vividas nas oficinas, supõe que fora dali, caso o usuário não tenha uma cultura e uma história de vida nas práticas corporais, dificilmente ele irá gerar este hábito. Certa vez, tivemos o seguinte diálogo com J.M., fato que implica outros indicadores:

"Pesquisador: Como você reconhece os usuários? Você tem uma preocupação em saber a história de vida deles?

J.M.: Sim, eu converso muito com eles. Quando eles chegam é papel de quem faz a acolhida escrever em seu prontuário um pouco da história deles. De como eles começaram a apresentar algum problema, alguma dificuldade em se socializar, estas coisas.

Pesquisador: E na acolhida, existe um protocolo, não é? Um roteiro de perguntas que orientam o profissional que está trabalhando na acolhida, não é?

J.M.: Sim, existe, mas a gente sempre vai além dessas perguntas. O objetivo é saber mesmo quem é aquela pessoa. Saber mesmo qual a sua história.

Pesquisador: Então, é possível saber por lá quais esportes ou atividade física que estas pessoas já têm experiência? Existe este registro em seus prontuários, não é?

J.M.: (Rindo, um pouco constrangido). Não. Isso não tem não..."

A importância de reconhecer a história de vida dos usuários, embora apareça no discurso de J.M. e também de outros profissionais do CAPS "A" não contempla todas as dimensões humanas do usuário. Este elemento nos faz refletir se no conjunto daqueles profissionais existe uma subjetividade social 
presente, naquele CAPS em particular, que vê a presença do professor de educação física como apenas um ator a mais na equipe sem necessariamente apontar com clareza qual o alcance e a real necessidade dele no projeto de assistência psicossocial em voga. O corpo se constitui, desde nossa perspectiva, muito mais do que apenas numa dimensão biológica. Possui uma dimensão cultural e histórica que parece ser desprezada na configuração subjetiva dos profissionais frente à atuação do profissional de educação física na saúde mental. Essa condição coadjuvante da educação física desfavorece um trabalho que vise a integração complexa entre corpo, subjetividade e modo de vida.

Ao procurar mais informações sobre a acolhida dos usuários, percebemos que a história que se quer conhecer dos usuários tem a ver com aspectos objetivos que de alguma forma tocam seu sofrimento. Embora não faça parte do escopo de nosso trabalho discutir como se configura o sofrimento dos usuários, este momento específico da pesquisa nos conduziu a perceber que a acolhida quer, na prática, adiantar um levantamento de dados sobre os determinantes comportamentais que levam o usuário a viver o transtorno. Perspectiva completamente distante de perceber o sofrimento e o transtorno como uma produção de sentido subjetivo, ideias levantadas por González Rey (2011a, 2011b, 2015) e discutidas em Goulart (2013b) observando a saúde mental no contexto do CAPS.

A ausência de um acolhimento que recupere a memória dos usuários em face às alternativas de trabalho que compõe de alguma forma as oficinas, especialmente a de educação física, indica uma desarticulação do processo de procurar estabelecer com o usuário uma possibilidade de a partir dele gerar caminhos ao seu próprio projeto terapêutico. Obviamente, trata-se de um desafio aos profissionais inseridos no CAPS, mas só possível, em nosso modo de ver, caso se rompa com a visão pragmática da assistência, fragmentada do trabalho e configurada numa subjetividade social que desacredita no usuário como sujeito capaz de gerar novos sentidos subjetivos e alternativas para a sua própria condição de sofrimento.

No âmbito da educação física, o caminho pedagógico e educativo por meio das práticas corporais deve ser considerado. Nesse sentido, é louvável o trabalho 
de J.M. que conduz sua oficina com traços e características extraídas de sua apropriação como educador. Aqui já mencionamos sua história como docente na educação física escolar. Em nossa aproximação à oficina nos ficou nítida a competência docente em torno de sua dinâmica expressiva e comunicativa e sua didática na forma de se dirigir e se relacionar com os usuários. Certa vez J.M. nos mostrou seus cadernos de planejamento da oficina. Perceber como J.M. organiza sua oficina e sistematiza suas ações neste caderno, nos fez pensar como tal organização se tornou mais um indicador importante para refletir as configuração subjetivas da atuação da educação física naquele contexto, em particular, na oficina de J.M.. Ao fazer isso, ao nos mostrar seus cadernos, J.M. marcava uma posição de atuação profissional que tal organização demonstrava seu compromisso e competência para seguir no trabalho da oficina. Nossa reflexão teórica projeta nisso outros sentidos que abrem um campo de visibilidade heurística para pensar se de fato, a trilha pedagógica da educação física que incorpora os componentes técnicos-didáticos já consagrados na área em seu diálogo com a escola é o melhor caminho também para o trabalho na saúde mental.

Nossa resposta, provisória, é não. O trabalho do CAPS e, sobretudo, o desafio profissional de promover a desinstitucionalização encerra uma complexidade epistemológica e de intervenção profissional que o debate acadêmico e científico da educação física ainda não acessou. Assim, nos parece bastante simplista legitimar a atuação da educação física na saúde mental tendo em vista a incorporação de seus instrumentais teóricos e metodológicos extraídos do saber escolar. A despeito dos avanços que a educação física brasileira gerou no campo educacional, a mera transposição do fazer pedagógico escolar da educação física para o campo da saúde mental na relação com sujeitos em sofrimento psíquico nos parece insuficiente. Tendo em vista as configurações subjetivas da atuação da educação física compreendida em nossa investigação, tal estratégia confere inadequações aos princípios fundamentais da reforma psiquiátrica brasileira e principalmente com aqueles que pressupõe um serviço disposto a enfrentar o problema da institucionalização. Nesse sentido, nossa hipótese é que se recupere e se tenha como núcleo de qualquer processo de 
trabalho em saúde mental, inclusive na educação física, a preservação da condição de sujeito do usuário, desde nossa perspectiva teórica, no qual o sujeito reclama um serviço que não rotule seu sofrimento em parâmetros biomédicos discutíveis e nem destitua dele o agir e decidir sobre os principais processos de sua recomposição mental. Isso requer ações de natureza educativa que se estabeleça por aquilo que o campo da Educação pode oferecer em respeito a uma ética do sujeito e não pelas suas perspectivas técnico-instrumentais.

A presença da educação física pode fortalecer movimentos que potencializem a desinstitucionalização. Nesse sentido concordamos com Wachs e Fraga (2009). Entretanto, é necessário operar com uma lógica ainda a ser construída pela educação física em sua interface com a saúde mental. Como possibilidade, é necessário promover ações que debatam a importância de se pensar a intervenção em educação física na saúde mental de forma contextualizada ao serviço e as diretrizes de trabalho do CAPS (projeto terapêutico). Ademais, defender que as práticas pedagógicas e educativas da educação física, orientadas para a promoção da saúde - mais do que a incorporação técnico-instrumental - devem tomar como princípio ações que facilitem a emergência dos sujeitos que, por sua vez, devem ser capazes de se posicionar ativamente em relação a sua saúde em diferentes contextos da vida. Concordando com González Rey (2011a), o posicionamento da pessoa como sujeito do processo de mudanças em seu modo de vida é fundamental para o seu desenvolvimento. Observando o contexto da saúde mental, esse princípio parece ser ainda mais relevante. 


\section{A educação física em meio a uma equipe multiprofissional em CAPS: competência e legitimidade em saúde mental}

O cenário investigado do CAPS "A", como fora anteriormente mencionado, se caracteriza como um espaço no qual a presença da educação física se constitui como uma área profissional integrada à organização administrativa do trabalho, junto às demais áreas. Não há dúvidas de que o trabalho da educação física neste espaço possui uma história e pode ser representada pelos profissionais que lá já estiveram e que hoje ainda trabalham. Entretanto, a instalação da educação física como mais uma área no conjunto das profissões presentes no CAPS carece de um maior entendimento da parte de todos estes profissionais. A subjetividade social do CAPS "A" nos oferece elementos importantes para discutir os desafios que se apresentam à educação física em se estabelecer num espaço ainda orientado pelo campo da saúde em sua constituição biomédica.

Pontualmente, esta seção da construção da informação nos convida a pensar sobre formas de se compreender a relação do profissional de educação física com os demais profissionais do CAPS. Tal relação se mostra configurada em hierarquias de acordo com a perspectiva medicalizadora do serviço, fato que contraria a perspectiva reformista do CAPS com relação às críticas direcionadas ao modelo manicomial na saúde mental e que revela uma tendência a alguns processos de institucionalização ${ }^{25}$. Elementos que estão circunscritos ao "status científico" de cada área de conhecimento parecem constituir uma subjetividade social que estabelece relações verticalizadas no processo de trabalho e que são naturalizadas pelos próprios profissionais do CAPS.

A saúde mental, de forma geral, não integra as intervenções profissionais da educação física brasileira. O CAPS acaba sendo um espaço de trabalho inusitado para área. Os currículos de formação em educação física não incluem

\footnotetext{
${ }^{25} \mathrm{O}$ tema da institucionalização diretamente não compreende os objetivos do estudo, embora essa discussão atravesse as ideias aqui apresentadas. Nesse sentido, destaca-se a pesquisa de Daniel Magalhães Goulart em nível de mestrado e defendida na Faculdade de Educação da UnB. Trata-se do estudo intitulado "Institucionalização, Subjetividade e Desenvolvimento Humano: abrindo caminhos entre educação e saúde mental" e que teve a orientação do Prof. Fernando González Rey.
} 
um conjunto de conhecimentos (tradicionais) que abarcam um eventual trabalho com sujeitos com transtornos psíquicos que geralmente se relacionam com as áreas médicas e da psicologia. Entretanto, num primeiro momento, há uma percepção dos sujeitos envolvidos no trabalho no CAPS que irá mitigar a ausência de uma preparação profissional apriorística à atuação. Embora, mais a frente isso vá entrar em contradição durante as ações do trabalho, sobretudo em momento de organização coletiva e planejamento.

Em trecho de conversação com os profissionais do CAPS, a ideia de que "ninguém está a priori preparado para atuar no CAPS" parece hegemônico. $O$ conteúdo desse pensamento pode ser percebido na seguinte fala de R.L. (psicóloga, 42 anos e 5 anos no CAPS):

"Ninguém estudou para estar no CAPS. O pessoal da psicologia se formou na verdade para atuar na clínica. Eu queria ter meu consultório, mas como não tinha dinheiro eu fui fazer o concurso na secretaria municipal de saúde. Quando entrei foi um choque. No começo foi bem difícil, mas aí você vai entendendo como funciona essa nova lógica do cuidado e sempre tem outras pessoas mais experientes. Mas a faculdade não prepara para atuar na saúde mental no serviço público. Isso a gente aprende na prática".

Há elementos importantes neste trecho que compreendem uma configuração de sentido subjetivo que transcendem (diretamente) os objetivos que aqui se propõe destacar. Por exemplo, quando R.L. aborda o desejo de "ter seu próprio consultório", mas não o realiza por questões de natureza financeira, reforça uma percepção de que os profissionais se adentram ao CAPS a partir de motivações externas à natureza do trabalho em saúde mental. Excetuando os médicos, as demais profissões presentes no CAPS encontram dificuldades de consolidação no setor privado. Assim, o setor público de saúde no contexto brasileiro acaba sendo um "porto seguro" a esses profissionais que procuram legitimamente se manter na profissão a despeito do lugar ou da natureza do trabalho. 
Retornando a fala de R.L. e aos objetivos que centralizam esta discussão, parece haver consenso na ideia de que os profissionais - exceto o psiquiatra não iniciam suas carreiras no CAPS preparados e seguros do ponto de vista das competências para o trabalho na saúde mental. Existe um nível simbólico nessa compreensão que dispõe sobre um contexto de relações horizontalizadas frente à qualificação profissional dos trabalhadores do CAPS, ou seja, todos comungam a mesma dificuldade inicial. Além disso, também é consenso que o serviço precisa preservar sua orientação multidisciplinar. Entretanto, algumas ações observadas ao longo da pesquisa e outros trechos de conversação podem, de alguma forma, contradizer essas percepções.

O CAPS se organiza a partir de uma orientação coletiva do trabalho e por isso, reuniões de planejamento de equipe acontecem regularmente ao longo de toda semana, as quais foram acompanhadas pela pesquisa com regularidade. $O$ primeiro ponto que alude a ideia da existência de uma subjetividade social que naturaliza a distinção qualitativa entre os profissionais é a ausência constante do médico-psiquiatra nas reuniões, pois,ua presença só é requerida em casos específicos em que a gravidade no estado de algum usuário reclama a opinião médica. A aceitação desse hábito contraria sobremaneira princípios importantes da atenção à saúde mental em consonância às bases da reforma psiquiátrica brasileira e, sobretudo, aos objetivos do CAPS. Ademais, alguns trechos de conversações extraídas das reuniões podem trazer outros indicadores que reforçam essa compreensão. Como por exemplo, a fala de M.C. (psicóloga, 49 anos, 5 anos no CAPS e gerente do CAPS) durante a discussão de proceder frente a alguma alternativa terapêutica para usuários que reincidentemente retornavam ao CAPS após processos de alta médica:

"Vamos nos organizar em duplas para pensar outras oficinas específicas para os usuários mais antigos. Pode ser qualquer composição de duplas. Fica fora sempre o psiquiatra e algum psicólogo, a gente pode se revezar nisso. De acordo com a oficina a gente discute com o psiquiatra o uso de medicamentos e horários e a gente da psicologia observa a evolução do quadro". 
Algumas explicações são importantes na análise desse trecho. Nele o que se destaca é a compreensão de que é necessária uma suposta supervisão do trabalho por determinados profissionais, quais sejam, os psiquiatras e os psicólogos. Assim, a tradição medicalizadora do trabalho se expressa nos discursos e nas ações que orientam o trabalho na saúde mental, embora a perspectiva teórica e normativa do cuidado no CAPS seja outra.

O profissional de educação física possui pouco protagonismo decisório nas ações do CAPS levadas à discussão durante as reuniões de equipe, sendo reservado a ele, atividades operacionais. Para ele, o ambiente hierarquizado se evidencia de forma naturalizada e suas motivações não abarcam possibilidades de eventuais transformações nesse contexto. Em parte, isso é reforçado por sua compreensão disciplinar e unilateral das intervenções da educação física:

"A atividade física entra como uma prática complementar ao serviço. É claro que observo o quadro de melhora dos pacientes e acredito que tem a ver com as nossas atividades. $E$ isso também é dito pelos psicólogos que estão acompanhando estes mesmos pacientes. Mesmo assim, é preciso sempre estar atento quais são as restrições médicas de cada um, principalmente porque alguns medicamentos interferem no ânimo e no metabolismo dos pacientes" (J.M., professor de educação física, 31 anos, 2 anos no CAPS).

Para J.M., a intervenção da educação física tem caráter acessório. Sem se perceber, J.M. ao mesmo tempo em que se posiciona em face aos supostos resultados positivos de sua atuação, também sugere que há uma autonomia relativa nas opções metodológicas de seu trabalho, uma vez que ele está condicionado às prescrições médicas. Outro ponto relevante é que a intervenção se submete aos cânones biologicistas da atividade física sem levar em consideração as possibilidades de construção de práticas corporais pensadas segundo os processos de configuração subjetiva de usuários em sua relação motivacional de vivenciar tais práticas em coletividade e assessorada por um profissional, aspecto abordado na seção anterior. 
Assim, para além daquilo que já foi discutido, o que nos parece pertinente destacar tem a ver com a forma com que J.M. se submete às diretrizes médicas no que tange ao uso de psicotrópicos. Seu posicionamento sugere uma produção de sentido subjetivo de assunção à competência e à autoridade médica. Levando em consideração a inserção da educação física ante o debate no campo da saúde, não seria uma contradição tal posicionamento? Ora, mesmo fora das questões afeitas ao universo da saúde mental, a educação física - em suas correntes mais progressistas e as que dialogam com a saúde coletiva - tem marcado uma posição de confronto à lógica de dependência ao uso de medicamentos. Mesmo as correntes da educação física que operam segundo a lógica exclusiva da biodinâmica, discutem os efeitos do exercício como um esteio importante para a saúde e redução da necessidade de uso de fármacos. $O$ contexto da saúde mental pode esclarecer por que J.M. mantém uma atitude passiva e de subserviência laboral aos demais colegas, principalmente à psiquiatria e à psicologia. Destarte, entendemos que J.M. é pressionado por uma subjetividade social que não reconhece de fato - senão apenas pelo discurso - o papel social e o alcance das intervenções da educação física na saúde mental. Isso deve ser relativizado, pois é evidente que a incipiente inserção da educação física neste cenário é, certamente, um desafio para os profissionais que lá estão. É algo, como defendemos aqui, a ser construído. Entretanto, nos parece que um caminho que não deve ser seguido é o de obliterar, do profissional, sua condição de ser sujeito do processo de seu trabalho com todas as dificuldades que isso talvez, num primeiro momento, possa acarretar.

Outrossim, compreendemos que o que está ausente em J.M. é sentir-se competente frente aos desafios que o CAPS encerra. Antes, é importante lembrar que isso só parece se configurar subjetivamente em J.M. quando a educação física está "integrada" às demais profissões. Isso não ocorre quando o trabalho é exclusivo da educação física. Poder-se-ia apresentar determinantes externos ao problema de sentir-se incompetente frente ao trabalho, o que inclusive aparece no discurso de J.M. quando certa vez dialogamos: 
“Pesquisador: Até que ponto sempre é necessário pensar as suas práticas a partir das orientações do médico?

J.M.: Não é que seja obrigatório. Mas a gente trabalha em equipe, então é sempre importante levar em consideração todas as informações. E convenhamos, nós não temos formação específica para atuar aqui no CAPS. A gente vai aprendendo.

Pesquisador: Mas olha, Você certa vez me disse sobre a complexidade que é isso aqui, você acha que o médico possui uma formação que dá conta dessa complexidade?

J.M.: Acho que não, mas ele tem reconhecimento. E a psiquiatria tem relação direta com o CAPS. É diferente da gente da educação física. A gente não se preocupa em estudar a mente humana”.

A compreensão de J.M. é que a formação inicial diferencia qualitativamente a educação física da psiquiatria, no que diz respeito ao trabalho na saúde mental. As dificuldades da formação inicial seria a forma de externalizar o problema de se sentir incompetente. Em parte, J.M, tem razão. A formação inicial precisa passar a se preocupar com a ascensão da saúde pública, em especial da saúde mental. Entretanto, é necessário discutir que tipo de formação em psiquiatria é necessária para romper com a lógica da institucionalização e trabalhar, de fato, em prol da promoção da saúde mental. Na medida em que se observa uma forte presença de uma subjetividade social que assume a doença mental como objeto e dela surgem as ações de confrontação em meio a lógica da cura, dificilmente outras possibilidades de trabalho em cuidado e promoção da saúde mental terão entrada e aceitação em CAPS.

O posicionamento pouco protagonista de J.M. quando da realização de reuniões, de alguma forma, fortalece a compreensão dos demais profissionais de que a educação física pouco pode influir em decisões estratégicas para além daquelas que se destinam a organização de atividades e eventos. Na escola, o professor de educação física é aquele sujeito que possui perfil para as atividades 
festivas e de organização de eventos. Tal característica parece também estar presente no CAPS "A". Tais afirmações não querem inferir que participar destas atividades como protagonista diminui a importância da educação física no cenário de um CAPS. Ao contrário, em nossa opinião, protagonizar estes espaços é uma virtude deste profissional, já que defendemos que são nestes espaços alternativos que se potencializa a emergência nos sujeitos de novos sentidos subjetivos de enfrentamento à condição de sofrimento. Contudo, é necessário refletir sobre a subjetividade social do CAPS "A" que nos oferece o entendimento que tais atividades são meramente operacionais. É como se a educação física fosse convidada às demandas instrumentais, e aos demais profissionais, as de ruptura e transformação, que se assentam no contexto complexo do cotidiano do CAPS.

Visto isso, entendemos como necessária e premente o estabelecimento de uma educação física assentada na competência para atuar na saúde mental. A competência que nos referimos deve estar atrelada às formas de se pensar as práticas educativas da educação física não submetidas à tradição médica que contradiz a reforma psiquiátrica. Nesse sentido, defendemos que a educação física se aproprie dos princípios da reforma e que faça valer sua prática centrada nos corpos dos sujeitos sem que os sujeitos se destituam de sua corporeidade. Em outras palavras, isso quer dizer que ao professor de educação física caberia iniciativas de abertura e alternativas para a emergência dos sujeitos, que por sua vez, levariam à cabo seu projeto terapêutico, integrando a eles as práticas corporais. No âmbito das relações profissionais, a apropriação dos princípios da reforma contribuiriam para a educação física se apresentar competentemente ao debate da construção dos processos de trabalho no CAPS.

Em nossa opinião, a legitimidade da educação física na saúde mental não se estabelece por força das normativas que oportunizam sua presença no CAPS. Talvez pudéssemos chamar esta de legitimidade "de direito", pois, a legitimidade "de fato" precisa se configurar em meio a produção de uma história da educação física a ser construída no CAPS e que ofereça uma abertura à promoção da saúde mental. Entendemos que uma via fundamental para isso é a absorção da teoria da subjetividade numa perspectiva cultural-histórica como eixo do processo de formação e trabalho. 


\section{À guisa de conclusão}

Com a intenção de concluir as análises e proceder frente a uma síntese do processo construtivo-interpretativo das informações, destacamos abaixo alguns pontos que merecem atenção e podem concorrer para o processo de qualificação do trabalho da educação física na saúde mental em CAPS.

a) A intervenção da educação física, comprometida com uma perspectiva de promoção da saúde deve dirigir sua atenção a uma conduta educativa que facilite a emergência do sujeito e que as práticas corporais que nucleiam o trabalho, componham um ambiente de integração e de decisões compartilhadas entre profissional e usuários. Nesse sentido, é preciso superar a lógica de centralidade do processo em torno do profissional que media dinâmicas por meio de práticas corporais, procurando sempre que possível atrelar e implicar emocionalmente os sujeitos da prática, recuperando para isso, aspectos que envolvam sua história e cultura como expressões importantes à constituição de vivências das práticas corporais. Com efeito, é mister problematizar sobre a articulação entre professores de educação física e usuários-sujeitos das práticas corporais. Como viver as práticas corporais respeitando as singularidades e incentivando para um coletivo/grupo estratégias de ações que os possibilitem viver e confrontar o sofrimento e o transtorno? Sobre tal questão se assenta a necessidade premente da educação física experimentar o contexto concreto da saúde mental por meio do CAPS e assim, produzir segundo as experiências vividas, outras noções de produção de subjetividade em torno da própria especificidade da área, qual seja o corpo e o movimento.

b) A defesa de uma não imposição de prática pedagógica tradicional da educação física no CAPS e a produção de intervenções geradas recursivamente às necessidades e demandas dos usuários do CAPS. Nesse sentido, observa-se a importância de se pensar o novo para a educação física que tem como (novo) desafio produzir intervenções qualificadas para atender um projeto terapêutico. O projeto pedagógico da 
educação física, expressado no contexto da escola, pode contribuir desde que se preserve sua dimensão educativa e ampliada de formação humana. Assim, os aspectos técnicos-didáticos-instrumentais não parecem, em nossa opinião, traduzir as necessidades que todos os meandros da complexidade que a saúde mental encerra. Essa dimensão técnicoinstrumental na qual se opera à didática da educação física, no bojo de suas teorias pedagógicas, pouco nos oferece de auxílio para pensar o novo em educação física e seus desafios de produzir intervenções qualificadas em saúde mental. Logo, um problema surge a fim de ser mais bem adensado: em que medida a herança da educação para a educação física pode, de alguma forma, valorizar suas intervenções pedagógicas? Sobre tal questão, entendemos que a educação pode ser assumida pela educação física quando esta eleva o indivíduo a uma condição de protagonismo de suas práticas. O corolário disso é fazer com que emerja uma ética do sujeito (GOULART, 2013b), que no contexto da saúde mental necessita se confrontar com a hegemonia da doença como objeto e da cura como solução, mas ao vencer esta contradição, pode abrir caminhos de vida para - como queria Paulo Amarante - fazer nascer novos sujeitos de direitos e novos direitos para os sujeitos.

c) A configuração subjetiva social que expressa uma tendência à hierarquização de áreas de conhecimento que contrariam a perspectiva de trabalho multidisciplinar do CAPS é um ponto fundamental de reorientação da prática social nesta instituição. A formação científica dos profissionais envolvidos no trabalho deve atender a uma pluralidade de competências que possibilitem um diálogo horizontal frente às especificidades do trabalho na saúde mental. Nesse sentido, caberia a educação física pautar uma formação generalista e cientificamente adequada à interlocução com outras ciências. Em especial à saúde mental, é preciso uma formação que se relacione a compreensão de ciência complexa e que assimile como fundamental os processos de subjetivação de suas práticas laborais. Há pela frente o desafio de se concretizar um compromisso social que elege $o$ 
trabalho na saúde mental uma instância profícua dos processos formativos e possíveis de intervenção profissional em educação física. Com efeito, deve-se exigir uma competência científica humanista da parte do profissional de educação física na apropriação de conhecimentos de outras áreas que agregam valor ao trabalho interdisciplinar no processo de desenvolvimento de relações horizontais com relação aos demais profissionais. 


\section{CONFIGURAÇÕES SUBJETIVAS DA PRÁTICA DA EDUCAÇÃO FÍSICA EM CAPS: PRODUÇÃO DE SENTIDO EM QUEM VIVE ÀS PRÁTICAS CORPORAIS}

Esta parte da construção da informação se constitui como o segundo eixo temático deste capítulo. Sua elaboração possui um espaço empírico distinto da primeira seção, embora seja inevitável não aprofundar reflexões e conclusões de forma recursiva à experiência anterior, na qual a educação física estava institucionalmente presente. A cena empírica que nos ajudou a compor este eixo temático da construção da informação foi o CAPS "B" que não possui o professor de educação física formalmente instalado e integrado como parte da equipe de seus profissionais da saúde mental. Visto isso, passamos a considerar ainda nosso objetivo de refletir sobre as configurações subjetivas da atuação da educação física na saúde mental, embora isso tenha sido feito de forma ressignificada, observando que a ausência do profissional de educação física se choca com a necessidade e o desejo subjetivado em ações daqueles profissionais que estão trabalhando no CAPS "B". Percebemos neste cenário, no qual as dificuldades e crises do espaço social e político da saúde mental, uma possibilidade de experimentação de ressignificar o trabalho da educação física projetando e enaltecendo a emergência das práticas corporais como instância de produção de sentido subjetivo e valorização dos sujeitos nos processos educativos e abertura alternativa às formas de se lidar com o transtorno.

Duas seções compõem este eixo temático. A primeira procura situar o contexto da cena empírica à luz de sua subjetividade social e como que o conjunto dos profissionais do CAPS "B" não se submetem as mazelas e a precarização do setor público em saúde mental em sua região. A categoria da subjetividade social nos permitiu avançar e nos projetar como pesquisadores na busca por um espaço de ressignificação do trabalho em educação física na medida em que o CAPS "B" ofertava, por meio de ações e não somente do discurso, dinâmicas de trabalho que operavam com as práticas corporais, no caso, com o futebol. A segunda seção, mais alargada, discutimos um desdobramento importantíssimo das configurações subjetivas da atuação da educação física, um dos fulcros desta tese que é pensar as práticas corporais 
como produção de sentido subjetivo, abandonando às concepções funcionalistas e teleológicas de corpo quando se trabalha com atividade física, que será melhor explorado ao longo desta seção.

Da mesma forma que fizemos com o primeiro eixo temático, produzimos ao final, uma síntese das discussões e novamente levantamos outros problemas que surgiram em meio à construção, mas que durante a pesquisa não fomos capazes de acessar e, assim, deixamos a cargo de novos projetos de investigação.

\section{Breves reflexões sobre a subjetividade social do CAPS: conjuntura política da saúde mental e a emergência das práticas corporais como resposta terapêutica}

Como forma de introduzir a construção da informação e fortalecer o tecido construtivo-interpretativo neste eixo de análise configurado a partir do protagonismo dos usuários de CAPS que vivem as práticas corporais, faremos um giro para além de nossos objetivos mais pontuais a fim de situar o contexto social deste CAPS naquilo que nos aproxima das configurações subjetivas da atuação do professor de educação física. Faremos isso por meio de uma breve discussão sobre a subjetividade social do CAPS "B" e de como nossas interpretações destacam a abertura para a inserção da educação física na saúde mental.

$A$ área de educação física não está presente no CAPS "B", entretanto, o corpo está. O que nos surpreende é que a despeito da presença de um professor de educação física, os serviços de assistência psicossocial deste CAPS, por meio de seus profissionais e através de uma escuta sensível, perceberam a necessidade de dar voz ao corpo e fazer valer um desejo subjetivado de seus usuários, que era o de participar de dinâmicas que envolvessem práticas corporais. Conversando com os profissionais do CAPS "B" e recuperando um pouco a memória do trabalho efetivado por eles, a ausência de práticas corporais integradas a um projeto terapêutico sempre se mostrou uma incoerência. Era como se o serviço psicossocial entendesse que o enfrentamento dos estados de transtorno pudessem se resolver exclusivamente ao nível do psicológico. 
$\mathrm{Na}$ opinião desses atores, tal incoerência partia do próprio poder público no âmbito da saúde mental e responsável por instituir as políticas de saúde daquele território. Para os profissionais do CAPS "B", que vivem o cotidiano da saúde mental, a política tende a incorporar um discurso que escamoteia outros interesses. A palavra de ordem no CAPS "B" é o de reinserção social. Esse discurso se mostra mais contundente nas orientações e diretrizes políticas. Tratase assim, não do discurso que sinaliza para indicadores que fazem emergir a subjetividade individual dos profissionais que lá estão, mas sim, de um discurso que imprime uma intencionalidade política objetivada em portarias e normativas. Mas entre a política instituída e as configurações subjetivas do trabalho em saúde mental há uma trama complexa que desencadeia um conjunto de ações que geram tensões entre os sujeitos que trabalham na vanguarda do que deseja a política.

O discurso político que procura escamotear outros interesses tem a ver com a desinstitucionalização, conceito importante e tomado como princípio do trabalho em CAPS. Entretanto, tal conceito neste território opera segundo a lógica norte-americana de desinstitucionalização, aquela que procura descronificar ou, como prefere a administração pública de saúde deste território, reinserir na sociedade os usuários, com vistas a desonerar e desobrigar o estado frente às políticas de promoção da saúde mental. Em nossa opinião, o poder público esquece que a reinserção, no correspondente à desinstitucionalização na tradição basagliana, opera com outros significados. A partir de nossa perspectiva teórica, a reinserção não se institui com o diagnóstico de "cura" ou "alta médica", mas se dá quando o sujeito gera alternativas para viver seu sofrimento de maneira não estática e paralisante, porque o sofrimento compõe a subjetividade humana, tal qual a felicidade. Ou como ensina González Rey (2011, p.313):

La salud psíquica no se define por la ausencia de conflictos, sino por la posibilidad de generar nuevos procesos de subjetivación en el decorrer de los mismos. Toda experiencia humana es conflictiva no por su carácter en si, sino por las propias producciones subjetivas generadas por la persona en el curso de su experiencia. Sin embargo, el sufrimiento psíquico aparece por la incapacidad de producir nuevos sentidos subjetivos frente a experiencias que se fijan como dolorosas y que impiden la emergencia de otros estados subjetivos, diferentes de esas 
vivencias dominantes. Considero que el trastorno mental es el resultado de ese proceso.

Logo, ao CAPS caberia criar as condições para que o sujeito pudesse produzir novos sentidos subjetivos para sua experiência de vida frente ao transtorno. Entretanto, nos parece que o caso deste CAPS investigado se assemelha àquilo que Amarante (1996) representou como a "desinstitucionalização como desassistência", uma vez em que o quadro profissional e a estrutura oferecida para a assistência ali parece estar longe de atender a demanda.

Esta compreensão sobre a conjuntura política local, que se configura na subjetividade social do CAPS "B" vai ao encontro dos índices de assistência e cobertura à saúde mental daquela região, uma das mais baixas do país. Nesse sentido, nos parece que aquele conjunto de profissionais vive a pressão do quantitativo de pessoas que procuram o serviço todos os dias. Contudo, é muito interessante perceber como tais dificuldades desencadeiam naqueles sujeitos os profissionais do CAPS "B" - uma produção de sentido subjetivo que os conduzem a criar alternativas em meio àquele contexto caótico. A implicação daqueles profissionais tem feito com que o trabalho exercido naquele CAPS seja uma referência na região. Assim, o CAPS "B" opera estrategicamente estabelecendo convênios e parcerias com instituições de ensino superior pública e privada, com voluntários e pesquisadores interessados na saúde mental. A associação com estes atores sociais tem sido fundamental para a implementação de um serviço minimamente qualificado.

Frente aos objetivos de nosso estudo e o debate sobre a inserção da educação física na saúde mental, é mister destacar que o CAPS "B", em face à construção de alternativas ao trabalho, como foi observado acima, faz emergir uma configuração subjetiva social fundamental para se criar um espaço de vivências de práticas corporais como instância importante ao projeto terapêutico dos usuários. Não ter receio das experiências e das iniciativas que procuram se juntar aos serviços de assistência, demonstram uma abertura para possibilidades de se criar o novo. Naquilo que contempla a educação física, embora oficialmente não esteja presente na figura de um profissional, as práticas corporais instaladas 
em oficinas no CAPS "B" demonstram uma subjetividade social que reconhece a dimensão de corpo para viver a integralidade humana e uma categoria importante na composição de um projeto terapêutico em saúde mental. Este reconhecimento, ao contrário daquilo que refletimos a partir do CAPS"A" não se configura ao nível do discurso. Ao contrário, se processa por meio de ações algo bastante caro à produção de sentido subjetivo e, desde nossa perspectiva teórica, contexto que aumentou ainda mais nosso interesse investigativo.

\section{Práticas corporais como produção de sentido subjetivo: vivências na oficina de futebol}

A oficina de futebol, no qual nos inserimos no trabalho do CAPS "B" possui uma breve história. A oficina nasceu de um desejo dos usuários, o que é bastante significativo e nos orienta para um indicador importante que se integra a alguns momentos de nossa cena empírica. M.D., 46 anos e a três no CAPS"B", revela-nos como começou a oficina:

"A gente sempre quis ter um espaço para jogar futebol aqui no CAPS. Os grupos que eu frequentava sempre tinha gente que topava jogar uma "pelada" ${ }^{26}$. Fora daqui eu frequento uma "pelada" de final de semana e nós sabíamos que haviam outras pessoas, aqui do CAPS mesmo, que também participavam. Então começamos a conversar nos grupos de apoio e também nas assembleias como seria legal ter o time do CAPS. A gente já tinha participado de torneio de futsal em outro CAPS, por isso nós queríamos um espaço para que a gente pudesse jogar entre a gente com mais frequência".

\footnotetext{
${ }^{26}$ Nome popular que expressa um jogo de futebol informal, no qual as pessoas jogam por prazer e numa perspectiva de lazer.
} 
M.D. participou de forma efetiva da construção de um espaço que ofertasse a prática do futebol para usuários do CAPS. Interessante como na fala não se instala uma preocupação teleológica ou funcionalista para a constituição de uma oficina de futebol numa instituição de práticas e cuidados com a saúde mental. As oficinas no CAPS"B" são parte do conjunto de ações que tem como objetivo atender o processo terapêutico dos usuários que apresentam algum tipo de transtorno mental. M.D. ao recuperar a história da gênese da oficina não menciona isso.

Ao não mencionar a finalidade de sua ação que sempre esteve ancorada em sua vivência no CAPS, D.M. permite-nos refletir como a oficina de futebol atende a uma dimensão do desejo dos sujeitos, a partir de uma produção de sentido subjetivo em torno do jogar futebol. A expressão de seu desejo não está vinculada em nenhum momento a uma condição do estado da doença mental, esta, ainda uma representação muito forte no CAPS. O futebol para D.M., é uma prática corporal que atravessa sua vida num nível simbólico-emocional, e por isso reiteramos sua produção de sentido subjetivo, que conduz seu esforço em mobilizar usuários e, sobretudo, os profissionais do CAPS"B" a fim de que se levasse adiante a ideia de se destinar um espaço para se jogar futebol no CAPS.

Incorporar o futebol como uma oficina e elevá-la à condição de parte do conjunto de serviços disponíveis aos projetos terapêuticos singulares dos usuários foi uma decisão dos profissionais do CAPS"B". Estabelecer oficialmente este espaço terapêutico, demonstrou a importância de uma escuta sensível de seus profissionais referente ao desejo dos usuários e, além disso, marcou sua posição de defender a assistência terapêutica segundo os termos ampliados do cuidado, integrando uma prática corporal às demais ações e tendo nela, um verdadeiro escape das práticas tradicionais do cuidado, como é o caso das psicoterápicas e psiquiátricas, estas ainda hegemonicamente presentes.

No trecho da conversação acima, D.M. faz menção a um torneio de futebol que ele e outros usuários haviam participado em outro CAPS. Nossa aproximação em meio a pesquisa nos fez compreender melhor como novas configurações subjetivas surgem quando o trabalho de uma oficina e, por consequência, o cuidado em saúde mental, transcende a própria oficina e abarca outros contexto e 
novas vivências. É claro que quando D.M. faz referência a esta participação, ele aponta um tempo anterior a da própria constituição da oficina. No entanto, uma trama se configura no processo de produção de informação que nos permite uma zona de sentido importante para discutir as contribuições específicas a uma oficina de práticas corporais, em especial, a de futebol. O torneio a que D.M. se refere tem acontecido nos últimos dois anos. Um CAPS localizado em outra região administrativa tem promovido intercâmbio esportivo em futebol. O CAPS"B" tem sido convidado e a gerência sempre organiza uma comitiva que acompanha os usuários nesse evento festivo.

O intercâmbio esportivo pode se fazer emergir novas configurações subjetivas entre os sujeitos da prática, pois, jogar um torneio ou jogar contra outras equipes promove uma abertura de viver um contexto distanciado da condição do transtorno e do sofrimento, pelo menos àqueles que paralisam o sujeito frente aos problemas da vida. Compreendemos que oficinas de práticas corporais possuem um potencial para desenvolver a promoção destas vivências que se abrem para novas configurações quando integram sujeitos que decidem ir além da dinâmica da própria oficina. O futebol, por ser uma prática corporal esportiva, convoca os seus participantes a viver a competição com seus pares. Entretanto, poderíamos refletir sobre outras práticas corporais que certamente são capazes de construir espaços de vivência para além das oficinas. Por exemplo, uma oficina de dança tem potencial análogo na construção de vivências performáticas. Tais atividades, que podem perfeitamente serem realizadas por meio de eventos, requer um nível de participação mais contundente dos usuários. Sua condição de êxito, depende em muito de como os sujeitos estão implicados àquela prática. Logo, a abertura de possibilidades para que os sujeitos se impliquem no processo de condução da oficina, resulta, em nosso modo de ver, na construção de um ambiente propicio à geração de produção de sentido que confronta o estado de sofrimento. Desse modo, abre-se uma alternativa desde o sujeito para enfrentar o transtorno.

Ademais, há outro elemento importante em torno deste debate. Sair dos espaços institucionais merece destaque como um recurso que inova no processo de assistência psicossocial, pois oportunizar o trânsito dos usuários para além 
dos "muros do CAPS" em meio às dinâmicas que se processam numa oficina podem produzir configurações subjetivas de autogoverno e emancipação. Tratase de um passo importante à desinstitucionalização. Como queria Basaglia, promover a reabilitação em meio à cidade, com liberdade e autonomia, porque só assim é possível ofertar um espaço social de validação social dos sujeitos, dandoIhe as condições para a subjetivação de sua própria história.

Durante nosso processo de investigação, participamos da preparação do CAPS"B" para receber pela primeira vez, outros usuários de CAPS para a realização de um torneio de futebol ${ }^{27}$. Segue o seguinte trecho de uma conversa com D.M.:

“D.M.: Era uma promessa nossa fazer o torneio aqui. Geralmente a gente é que vai para lá jogar com eles. Aqui também é mais fácil para chamar outros CAPS e assim aumentar a quantidade de equipes.

Pesquisador: E como vocês se organizam? Todo mundo joga?

D.M.: Sim. Aqui a gente consegue fazer dois times. A gente faz o time A e o time B. O CAPS de lá consegue mais dois no mínimo. Lá eles jogam todo dia. Nem precisa estar no CAPS para jogar.

Pesquisador: Ok, mas como acontece esse torneio? Tem tabela de jogos? Tem juiz? Como fica a organização disso?

D.M.: A gente organiza tudo. Montamos os times e vemos quantos times tem o torneio. A gente monta a tabela encima da quantidade dos times. Queria ver se a gente consegue arranjar um apoio para as medalhas e o troféu.

Pesquisador: E tem premiação também?

\footnotetext{
${ }^{27}$ O torneio não aconteceu. A greve dos servidores da saúde do DF acarretou o cancelamento das atividades da oficina de futebol. Omitimos essa informação na elaboração de nosso processo de construção do cenário de pesquisa, porque embora a oficina tenha sido suspensa, nós continuamos presentes no CAPS "B". O CAPS continuou a operar em alguns atendimentos e trabalhos administrativos.
} 
D.M.: Claro. Tem que ter. Eles lá são muito competitivos. E na verdade é uma festa. A gente vai ter torcida aqui do CAPS. A gente tem que levantar o troféu para todo mundo ver".

Há aspectos muito interessantes na forma em que os sujeitos da oficina, em especial D.M., se envolvem em torno da atividade de futebol e, especificamente nesse momento de intercâmbio promovido pela organização de um evento de natureza esportiva. Para D.M., retribuir os colegas de outro CAPS, organizando novo torneio é quase uma obrigação, mas uma obrigação permeada por uma gentileza e cordialidade, na qual se torna a expressão de ver na prática do futebol um ponto em comum das duas unidades de CAPS, e sobretudo, dos usuários que praticam futebol por meio do CAPS. Para além do discurso, o esforço de D.M. está subjetivado em seu desejo de jogar em meio aos seus pares. Ele gostaria de que as pessoas próximas dele pudessem assisti-lo jogar.

A organização coletiva do torneio, capitaneada por D.M., nos permite discutir como as ações, no caso de cunho esportivo, abriram um espaço de produção de sentido subjetivo que conduz os sujeitos a um nível de envolvimento que rompe com o sofrimento, com a letargia e com a sua paralisia frente aos lugares comuns da vida, porque organizar um torneio esportivo, em determinados espaços sociais, como um clube por exemplo, ou mesmo na escola, é parte da "normalidade" da vida de sujeitos que gostam de esporte. Refletir sobre isso nos indica a seguinte questão: em que medida as ações e a forma de se organizar num grupo esportivo, faz com que os usuários do CAPS "B" se distingam qualitativamente de outros grupos sociais? Em nossa opinião, em nada se difere. Isso impõe à perspectiva psiquiátrica, que se funda na doença mental, pontos de tensão e dúvidas frente a sua lógica que opera com base na universalização de comportamentos e sintomas. Segundo nossa perspectiva teórica, o que conduziu D.M. e seus colegas ao CAPS foi uma produção de sentidos subjetivos que acarretou em configurações subjetivas de um estado de sofrimento e transtorno que em determinado momento de suas vidas os paralisaram. Todavia, a oficina de futebol, em meio às suas ações, tem possibilitado a estes sujeitos gerar novos sentidos subjetivos que 
contrapõe a condição do transtorno. Assim, entendemos que as práticas corporais, quando atravessadas de forma simbólica-emocional a vida dos sujeitos, podem promover novos caminhos para o desenvolvimento de alternativas no âmbito do trabalho em saúde mental com os quais contrariam a lógica da cura.

Nosso trecho de conversação com D.M. nos permite outros elementos que favorecem uma aproximação direta com uma eventual contribuição de um trabalho qualificado em educação física, como já afirmamos aqui, ausente no CAPS "B". Portanto, o que significa, para além da fala, organizar as equipes em "A" e "B"? Fosse apenas a projeção direta da análise da fala, poder-se-ia compreender que se trata simplesmente da representação da divisão de equipes com base na quantidade de pessoas que pretendem participar do torneio. Entretanto, os sentidos subjetivos não se configuram na expressão consciente e intencional da fala. Esse trecho de conversação impõe para nós, como pesquisadores, integrá-las a outros contextos de informações e expressões de subjetividade que nos permitem avançar teoricamente sobre as configurações subjetivas de D.M. Ao jogarmos juntos durante a oficina de futebol, outras expressões de D.M. sinalizam para configurações subjetivas em torno de uma concepção esportiva representativa das contradições do esporte no que diz respeito à exacerbação da competitividade e que geralmente forja um contexto às vezes opressor para aqueles sujeitos que não apresentam uma boa performance esportiva. D.M. joga futebol tendo a performance como uma condição subjetiva de seu prazer. Vencer significa produzir sentidos subjetivos que expressam prazer e felicidade. Perder, ao contrário, naquele momento significa produzir sentidos subjetivos que o tencionam e o abatem emocionalmente. Certamente, a divisão dos times em "A" e "B" significam organizar os usuários em equipes que melhorem suas performances esportivas para competir no torneio. No caso, a equipe " $A$ " com os usuários que apresentam melhor performance no futebol e a equipes "B" com os demais usuários, com pior performance. Isso merece de nossa parte algumas reflexões a partir de uma perspectiva educativa do trabalho da educação física no âmbito do esporte de participação e lazer, contexto da realização de um torneio de futebol para usuário de um CAPS. 
A ausência de uma orientação qualificada em educação física, observando a apropriação da área segundo uma concepção crítica de esporte, pode ser um entrave importante na dinamização de uma oficina esportiva em saúde mental. Isso se torna mais relevante porque a prática esportiva em si não representa um espaço educativo e nem um espaço de saúde. Nesse sentido, o que pode tornar as práticas corporais esportivas um espaço educativo e importante à promoção da saúde são as configurações subjetivas dos sujeitos que a compõe e a organiza. Ou seja, a oficina de futebol em si, não tem valor educativo e, tampouco, desde nossa perspectiva, valor terapêutico. Tudo irá depender de como os sujeitos que produzem a oficina vivem tais atividades, pois estas serão as fontes para as configurações subjetivas que podem, por sua vez, tornaram-se verdadeiras expressões de educação e saúde. No esporte, e no caso, no futebol, os rótulos também estão presentes e seria ingênuo não perceber que os rótulos (daquele que joga bem e daquele que joga mal) numa prática social em que o sujeito está implicado emocionalmente não afetam sua produção de sentido subjetivo. Em que pese a auto-organização da oficina de futebol pelos usuários ser uma dinâmica fundamental e que pressupõe implicação e compromisso com o seu próprio processo terapêutico, não quer dizer que se anula a importância da presença de um professor de educação física que possa contribuir na qualificação desse processo. Do contrário, estaríamos legitimando a ideia de desinstitucionalização como desassistência, já antes levantada aqui ao recuperar as contribuições de Amarante (1996). O desafio que surge em prol da desinstitucionalização é o de produzir formas nas quais se ofereça um serviço de assistência que preserve ou abra espaços de subjetivação para os sujeitos com transtorno. Neste caso, a educação física, orientada por um acúmulo de saber crítico diante de como se operam as práticas esportivas em sua instância hegemônica - aquele sob os signos do esporte de rendimento - pode ofertar espaços e situações que visualizem aos usuários as contradições que o esporte também encerra. Sobre isso, é fundamental que o trabalho da educação física, por ocasião de um professor de educação física que integra uma equipe do CAPS, abra possibilidades aos usuários e sujeitos de sua prática vias alternativas para produzir novos sentidos subjetivos frente aos valores e configurações 
subjetivas sociais presentes na hegemonia da prática esportiva. Em nossa opinião, isso fortaleceria o desenvolvimento de um trabalho para a promoção da saúde mental e, diferentemente de nossa discussão do eixo temático anterior, legitimaria a presença da educação física em CAPS por meio de sua perspectiva de trabalho e competência.

As práticas corporais orientadas como produção de sentido subjetivo, não subjaz a lógica determinista dos benefícios biológicos que induz o sujeito a pensar que realizá-la condiciona uma melhora em seu estado de saúde. Tal perspectiva tem sido bastante incorporada pelo senso comum e também por correntes epistemológicas da própria educação física que colocam na atividade física um dos principais determinantes para se "obter saúde". Para nós, orientados pelo pensamento de González Rey (2004), a saúde é um processo e não um produto. Com efeito, uma pessoa não obtém saúde, porém vive uma condição de saúde subjetivada em sua história e cultura com todos os determinantes sociais que isso engendra.

No CAPS "B", as práticas corporais, num primeiro momento, são legitimadas pelos usuários frente a estas representações de saúde. Há quatro anos no CAPS, E.A., de 38 anos compreende os "efeitos" da oficina de futebol em sua vida da seguinte forma:

"Fazia muito tempo que eu não jogava futebol. Mas quando eu era mais novo, sempre joguei na rua e era uma farra muito boa. Sempre gostei de futebol e jogar com os colegas de CAPS tem sido ótimo. Principalmente porque me sinto melhor ao longo do dia. É uma atividade que mesmo sendo recreativa a gente corre bastante, sai suado daqui e isso acaba melhorando nosso condicionamento e isso é bom para encarar os problemas da vida”.

Uma fala diferente, porém, sob o mesmo fulcro de representação de atividade física como um produto para a saúde, ofereceu-nos B.L. de 20 anos e há um ano no CAPS: 
"Eu pouco venho ao CAPS. Venho mesmo por conta do futebol. Minha mãe gostaria que eu participasse de outras de outras atividades. Ela entende que as outras atividades vão me ajudar a melhorar minha depressão. Eu não gosto. Prefiro vir só no futebol. Ela não reclama porque pelo menos acha que o futebol vai me ajudar a emagrecer. Acho que nisso ela tem razão, mas meu peso nunca me atrapalhou a jogar bem. Eu jogo bem futebol mesmo sendo gordinho".

Nestes dois pequenos trechos de informação, tanto em E.A. e B.L., surgem indicadores importantes ante a produção de sentido subjetivo no que diz respeito à compreensão deles sobre o alcance e a "finalidade" de participar de uma oficina terapêutica de futebol e também indicadores que vão além do debate em torno da dimensão teleológica das práticas corporais quando vivenciadas na saúde mental. A fala de E.A. e B.L. aconteceram em momentos de debate coletivos com os usuários logo após a realização da oficina de futebol. Do ponto de vista da Epistemologia Qualitativa, destaca-se a necessidade de se considerar na cena empírica um ambiente no qual se vive um contexto espontâneo para que os sujeitos colaboradores do estudo possam se expressar sem a obrigatoriedade de muitos direcionamentos. A associação do conjunto de expressões produzidos em diálogo com E.A. e B.L. nos permite refletir sobre as configurações subjetivas na relação destes sujeitos com o futebol no que tange as maneiras que tal prática corporal emergem na vida deles como forma de produção de sentido subjetivo e que, a partir disso, nos permite contradizer o discurso imediato que aparece no conteúdo do diálogo.

Em E.A. observamos que o futebol integrou, em determinado momento, a sua vida. Ele recorda-se com nostalgia um tempo no qual era possível brincar de futebol na rua e tal resgate de natureza lúdica parece fazer com que ele sinta prazer em dividir isso neste novo momento com os colegas do CAPS. Entretanto, E.A. continua "sua fala" inferindo que se sente melhor uma vez que a prática de futebol na oficina contribui para melhorar seu condicionamento físico e isso o leva a encarar e estar mais bem preparado para enfrentar os problemas da vida. Ora, não estaria E.A. sendo conduzido pelo discurso hegemônico e de ampla 
repercussão na mídia sobre o valor e os impactos da atividade física na vida das pessoas? Em que medida o bem-estar, confessado por E.A., não está mais atrelado ao processo de sentir e recuperar por meio do futebol uma história que atravessou um momento feliz de sua vida? Entendemos que o futebol - uma prática corporal - emerge em E.A. como produção de sentido subjetivo e acreditamos que de fato ele sinta um bem-estar, mas não apenas em função dos efeitos bioquímicos da prática do exercício. Sobre isso, E.A. vai além porque o futebol integra em sua história de vida aspectos simbólicos-emocionais que nos permitem destacar o caráter subjetivo de um sujeito que decide viver as práticas corporais e, além disso, faz com que E.A. atue expressando sua subjetividade e interagindo com seus colegas no CAPS de uma forma lúdica e prazerosa. A ideia de condicionamento físico extraída pelo discurso é frágil por algumas questões que fogem do arcabouço cultural de E.A. Mesmo do ponto de vista biológico, a prática da oficina de futebol do CAPS "B" pouco acrescenta em relação a ganhos de condicionamento físico. Isso se torna evidente na medida em que não se estabelece nenhuma dinâmica na oficina que oriente uma prática submetida aos princípios básicos do treinamento, como por exemplo, volume e intensidade do exercício. Ademais, a prática é realizada uma vez por semana, de forma que esta baixa frequência em torno de uma atividade física faz com que seja inócua frente aos ganhos de condicionamento físico.

A expressão dita por B.L. no que diz respeito a sua representação teleológica das práticas corporais nos provoca a refletir sobre outros elementos que transcendem nossos objetivos de discutir as práticas corporais como produção de sentido subjetivo. Isso porque nos parece que B.L. de fato pouco produz sentido no que diz respeito à consciência consagrada de que as atividades físicas contribuem para a melhoria da saúde. No caso, B.L. confessa que a sua mãe compreende tal lógica e por isso, inclusive, o permite permanecer na oficina de futebol mesmo que ele não se integre às demais atividades de seu projeto terapêutico. Logo, B.L. não está preocupado com os (eventuais) "efeitos" do exercício em seu corpo, sua produção de sentido quando joga futebol parece se configurar subjetivamente em outras direções. Observando o contexto em que B.L. tem se instalado no CAPS, tal produção de sentido subjetivo na prática do 
futebol não é algo pequeno em sua vida uma vez em que, de fato, a oficina de futebol tem sido a única possibilidade de acesso à B.L. em seu processo terapêutico no CAPS. B.L. não frequenta outras oficinas do CAPS embora seja extremamente participativo na oficina de futebol.

Tal expressão de sentido subjetivo em face a uma prática corporal no contexto da saúde mental nos permite refletir, de forma hipotética, sobre os alcances e os impactos das práticas corporais quando configuradas subjetivamente nos sujeitos com transtornos em CAPS. Diferentemente daquilo que a tradição da educação física poderia ofertar e que tem a ver com o senso comum orientado pelo discurso midiático, o alcance das práticas corporais quando realizadas na saúde mental talvez expressem bem menos os impactos biológicos no corpo com aquilo que se espera dela. A tradição da educação física, sobretudo quando situada no campo da saúde, tem colocado à frente do processo o corpo biológico como orientador de suas práticas educativas. Não seria o caso de se inverter essa lógica? Outrossim, pensar uma prática educativa que, por ser educativa, dever-se-ia nortear uma abertura de espaço para a emergência do sujeito que expressa sua subjetividade em torno das práticas corporais e que, orientado por um professor de educação física poder fazer repercutir hábitos saudáveis de vida de forma a transformar seu modo de vida e por consequência, promover saúde.

Outro ponto não menos importante e que o caso de B.L. nos possibilita avançar em nova zona de sentido tem a ver com o potencial das práticas corporais como aportes importantes para estabelecer vínculos com os usuários do CAPS. Geralmente, os usuários que procuram o CAPS vivem situações de sofrimento e transtorno imediato bastante agudos. Seu estado de apatia e fragilidade são aspectos que desafiam os profissionais de saúde mental a conduzirem estes usuários e iniciar com eles um processo de construção de um projeto terapêutico. Assim, na prática, a indução desse projeto por parte do profissional de saúde mental é bastante comum. Em B.L. vemos a indicação de suas dificuldades em viver o CAPS e que a única via que consegue vinculá-lo tem sido a oficina de futebol. Quando se observa boa parte das oficinas do CAPS, principalmente aquelas que tem no trabalho psiquiátrico ou psicoterapêutico a 
base de sua operacionalização, é preciso refletir sobre como as caraterísticas e dinâmicas de tais oficinas repercutem ou abrem espaços de produção de sentido subjetivos para os usuários que as vivem. Quando elas fazem isso, entendemos que elas avançam na criação de ambientes de subjetivação dos usuários que passam a viver um espaço na qual a possibilidade de se transformar em sujeito de seu processo terapêutico é contemplada. Isso pode ser observado na experiência de Goulart (2013), denominada Grupo de Redes, e que procurava intervir diretamente em sujeitos institucionalizados. Entretanto, uma parte considerável das oficinas psicoterápicas fogem dessa lógica, operando por meio da centralização do trabalho no profissional de saúde e encapsulando os usuários na oficina, ou seja, a oficina não oportuniza espaços que vão além da própria oficina. Em outras palavras, o usuário vive a oficina de maneira hermética, fora dela os trabalhos não fazem sentido. Ora, boa parte dos usuários só vivem as representações profissionais do trabalho psicoterápico após o transtorno. A sua história de vida pouco está atrelada à discussão de sua psique. Isso torna o desafio do trabalho em saúde mental ainda mais complexo no âmbito da intervenção dos profissionais da psicologia, por exemplo. Ao contrário desse contexto, as práticas corporais têm emergido na vida dos sujeitos desde a infância. Jogos e brincadeiras são atividades que forjam o espaço social das crianças, que em nossa perspectiva teórica, se desenvolvem integralmente por meio da vivência destes espaços sociais, sejam eles institucionalizados (na escola) ou não-institucionalizados (na rua). Com efeito, em nossa opinião, as práticas corporais se tornam importantes no trabalho em saúde mental porque podem implicar emocionalmente os sujeitos usuários do CAPS. Na perspectiva de ter as práticas corporais como uma produção de sentido subjetivo, o professor de educação física que trabalha em CAPS pode oportunizar aos usuários um espaço alternativo de subjetivação que do ponto de vista estratégico do serviço de assistência em saúde mental desenvolva um ambiente de vinculação inicial que outros serviços não conseguem.

Representar as práticas corporais por meio dessa perspectiva teórica nos parece legitimá-la e consagrar a presença do trabalho de educação física qualificado, não pela lógica biologicista dos efeitos do exercício no praticante, 
senão ao contrário, enaltecendo as formas em que o sujeito integra as práticas corporais em sua vida na expressão simbólico-emocional de praticá-las no CAPS e para além do CAPS.

\section{À guisa de conclusão}

Assim como foi organizado na seção anterior, produzimos uma síntese à guisa de concluir nossas análises e projetarmos de forma mais objetiva os aspectos discutidos no processo construtivo-interpretativo das informações e que abaixo recuperam e problematizam outros aspectos baseados neste segundo eixo temático, procurando assim, colocar em perspectiva outros aspectos que fortaleçam o debate da educação física na saúde metal.

a) As configurações subjetivas sociais do CAPS podem gerar mecanismos de enfrentamento ao poder público no que tange às dificuldades de produzir a assistência em saúde mental de forma qualificada e condizente aos princípios da reforma psiquiátrica brasileira, mormente aquele que objetiva os processos de desinstitucionalização. Com efeito, é necessário incorporar ao trabalho um conjunto de ações que visem ao máximo implicar os usuários e a comunidade no que diz respeito às novas formas de se operar o serviço. Os profissionais de saúde mental, ao defender o princípio da interdisciplinaridade como cerne do trabalho, resistem à lógica medicalizadora e hospitalocêntrica que ainda se vê em termos normativos traduzidos em políticas institucionais. A educação física e, sobretudo, as experiências autônomas em práticas corporais significativas aos usuários podem incidir diretamente na reelaboração das diretrizes programadas de assistência em saúde mental no Distrito Federal (DF). Não seria o caso de discutir no âmbito das políticas públicas do DF a necessidade do profissional de educação física como agente de saúde mental e parte do quadro de servidores público da saúde? 
b) A presença da educação física na saúde mental pode se tornar uma ação estratégica que oferece ao desafio da interdisciplinaridade novos aportes que podem, de alguma forma, tensionar o cuidado e a assistência nos caminhos de se afastar da perspectiva medicalocêntrica ou operada exclusivamente por dimensões cognitivistas e da ordem psíquica dos usuários atendidos em CAPS. Na saúde mental, especificamente no CAPS, o corpo expressado segundo uma concepção cultural-histórica pode ser elevado a uma condição de igualdade a outras esferas do cuidado e da assistência no que diz respeito às preocupações dos profissionais em saúde mental. Se assim o fizerem, estes profissionais estarão dando um passo importante para um serviço de educação integral e que, por consequência, caminha ao lado de ações que visem contundentemente promover a saúde mental dos sujeitos usuários do CAPS. Acreditamos que a utopia da desinstitucionalização de Basaglia passa por estas opções.

c) É fundamental para a educação física continuar as pesquisas no âmbito da teoria da subjetividade numa perspectiva cultural-histórica, a fim de adensar as elaborações teóricas que pensam as práticas corporais como produção de sentido subjetivo. Embora nosso estudo tenha se localizado no âmbito da saúde mental, outros cenários sociais aos quais a educação física também está presente, se tornam importantes no sentido de avançar sobre a ideia de ver no sujeito da prática o núcleo gerador dos processos de subjetivação que dão sentido as práticas corporais e que implicam o sujeito a modificar, as vezes radicalmente, seu modo de vida. Pensar as práticas corporais como produção de sentido subjetivo é valorizar o sujeito em detrimento do valor atribuído a uma determinada prática corporal. Queremos assim romper com a lógica de se criar uma espécie de "axiologia das práticas corporais". Em nossa opinião, isso em parte tem 
determinado a criação de rótulos sobre as práticas e sobre seus praticantes. Um exemplo pode ser oferecido frente às questões de gênero, quando se vincula a ideia de praticantes de futebol serem necessariamente homens, embora isso tenha se modificado bastante nos últimos anos. Ou a ideia de que as mulheres que praticam futebol ou handebol possuem tendência ao homossexualismo. Na esteira disso, que os homens que jogam voleibol também possuem tendências homossexuais. Ou que as práticas de artes marciais disciplinam os seus praticantes. Tais discursos retiram o sujeito como gerador do sentido que tais práticas corporais podem significar, pois é como se a prática corporal em si tivesse um valor social. Desde nossa perspectiva teórica, "fora dos sujeitos", tais práticas corporais não fazem sentido. Além disso, da mesma forma que o sujeito da prática é importante, o sujeito que media a prática, no caso o professor de educação física também precisa necessariamente torna-se sujeito de sua ação. Compreendemos que o trabalho da educação física diante desta perspectiva, trata-se de uma zona de sentido ainda não explorada na área e que nosso estudo procurou inaugurar. 


\section{V - Considerações Finais}

Onde há pensamento devem existir especulação, fantasia, desejo e todos os processos subjetivos envolvidos na criatividade do pesquisador como sujeito. Creio que o perigo não está na especulação, mas sim na sua separação em relação ao momento empírico, na reificação do especulativo que termina sendo uma forma de rotulação acrítica. Sentir medo da especulação é um fato institucionalizado e público de um medo oculto na instituição científica e acadêmica: o medo das ideias.

Fernando Luís González Rey 
Reza a tradição das monografias acadêmicas de que a conclusão de um trabalho em formato de comunicação científica deve evitar retornar ao debate teórico ou "ao diálogo" com os fundamentos e referenciais anteriormente levantados e discutidos. Espera-se assim que o autor demonstre uma conclusão que revele algo novo, ainda não aventado pelo conjunto de autores que o precedeu ou que o ajudaram a refinar seu objeto. Dessa forma, no corpo do texto da conclusão evitam-se novas citações e cotejamentos teóricos. Entretanto, vale romper com as regras tácitas da metodologia científica a fim de recrudescer e sublinhar contundentemente os limites de nosso estudo explorados na presente tese. Com efeito, destacamos as ideias expressadas na epígrafe que abre estas últimas considerações. O breve trecho, retirado do pensamento de González Rey, sintetiza aquilo que ansiamos para a educação física no que diz respeito à produção de conhecimento científico.

Ao longo do trabalho, não nos faltou esforço no que tange ao rigor metodológico explicitado na construção e na vivência do cenário empírico. Ao mesmo tempo, nossas elaborações teóricas tentaram não mitigar as ideias que iam se tecendo no confronto da tensão entre os processos empíricos e as categorias teóricas assumidas, quais sejam aquelas que atravessam a teoria da subjetividade numa perspectiva cultural-histórica. Por isso a epígrafe registrada nos é muito cara, pois os limites científicos da tese jamais se submeteram aos imperativos do "medo das ideias"...

Assim, a teoria da subjetividade de González Rey tornou-se a pedra angular da pesquisa, sem a qual os temas levantados ao longo da tese no âmbito da articulação do trabalho da educação física na saúde mental e no contexto da saúde pública brasileira, certamente não se sustentariam, ou talvez, nem viessem a emergir. As orientações da Epistemologia Qualitativa lograram estabelecer diretrizes em que no curso da pesquisa e na redação deste trabalho, procuramos integrar nossos interesses de investigação e assim, fossemos cada vez mais explorando os estudos oriundos da saúde coletiva, da saúde mental, da educação e da própria educação física com um olhar crítico.

Ao fim e ao cabo, uma pesquisa gestada a partir da Epistemologia Qualitativa não se permite às amarras inexoráveis das ilações científicas. Os 
registros e as ideias exploradas anteriormente durante o capítulo de construção da informação, caso foram redigidas se caracterizando por formas mais assertivas de posicionamento teórico, se deram em função de uma abertura para um debate necessário ao campo da educação física. Imaginamos que tais características facilitam e promovem um espaço melhor e mais instigante para o confronto de ideias.

Desde o início de nosso trabalho, a intenção foi de concorrer ao campo epistemológico da área e que, nessa primeira aproximação ao estudo da teoria da subjetividade de González Rey, se processou no contexto da saúde mental na saúde pública brasileira. Entendemos que o campo da educação forjou um espaço importante para que pudéssemos nos desafiar a compreensão de como a educação física, em seus processos interventivos de base educativa, pudesse se situar na complexidade do contexto da saúde mental num projeto de natureza terapêutica. Almejávamos que a exploração da teoria da subjetividade pudesse abrir uma linha nova de discussão teórica e epistemológica para a educação física e que a emergência do recente campo de trabalho na saúde mental fosse o cenário ideal para se levar adiante aspectos importantes do ponto de vista da intervenção profissional educativa neste contexto. Logo, à guisa de conclusão desta tese e de síntese do modelo teórico elaborado, alguns apontamentos foram organizados e correspondem às nossas provisórias conviç̧ões teóricas e, ao mesmo tempo, aludem à abertura de novos problemas de investigação:

- A perspectiva da promoção da saúde não deve se isolar ou circunscrever sua caracterização exclusivamente pelos determinantes sociais da saúde. Se por um lado tais determinantes devem ser considerados como um suposto à promoção da saúde, por outro, tais determinantes não se sustentam como seus condicionantes, caso o trabalho em saúde não contemple (e preserve) a emergência da subjetividade dos sujeitos da prática. Em outras palavras, a centralidade do trabalho deve ser deslocada para o sujeito da prática, sem o qual a perspectiva educativa da emancipação dificilmente se opera. Valorizar isso não corresponde a diminuir a importância do trabalho qualificado do profissional de saúde, entretanto, vale destacar que as competências científico-profissionais 
inscritas nas ações interventivas em saúde devem, em nossa opinião, se submeter aos sujeitos, e não o contrário. No âmbito da saúde mental, isso se assevera na medida em que o significado do transtorno ainda é palco de dissensões científicas. Desde nossa perspectiva teórica, o transtorno é uma produção subjetiva, e como tal, deve ser superada integrando o sujeito do transtorno e não por medidas externas a ele. No que tange a atuação do profissional de educação física que se instala no CAPS, sua intervenção deve se submeter aos usuários, procurando para isso estender seus objetivos no desenvolvimento de práticas corporais que alcancem (ou promovam) de alguma forma a produção de subjetividade dos usuários. A cultura e a história dos sujeitos, atravessada simbólico-emocionalmente quando vivem as práticas corporais, deve ser objeto de preocupação do profissional de educação física responsável pela mediação do processo de assistência e cuidado do usuário em CAPS.

- Em se tratando de práticas sociais, não se produz "o novo" exclusivamente com o movimento do pensamento do ideal, ou seja, a teoria induz/explica, mas não determina uma realidade ontologicamente complexa. Nesse sentido, é fundamental recrudescer o desenvolvimento da pesquisa científica na educação física no cenário da saúde pública e, sobretudo, no contexto da saúde mental, sem a qual o seu trabalho neste espaço social será a mera reprodução de outros espaços socialmente tradicionais da área. Com efeito, o subsídio educacional de dimensão pedagógica ou mesmo o da biodinâmica na dimensão do exercício para o trabalho na saúde mental nos parece algo suplementar e não fundamental. No caso, defendemos que "o novo", no que diz respeito à atuação de professores de educação física em CAPS, seja processado em meio ao crivo da realidade cotidiana do contexto da saúde mental. Assim, seria fundamental que a área passasse a integrar cada vez mais os projetos de assistência à saúde mental das secretarias de saúde municipais. O corpo, objeto fundante da educação física, não pode ser obliterado das políticas públicas que 
objetivam a promoção da saúde mental, conquista brasileira desde a constituição cidadã de 1988 e alvo das mais recentes discussões políticoacadêmicas no que se refere ao desenvolvimento da saúde como direito social. Contudo, ao mesmo tempo em que defendemos a instalação de novos postos de trabalho para a educação física como agentes de saúde e a consolidação daqueles já contemplados, é mister avançar no correspondente à formação acadêmica, pois esta deve passar a se preocupar com a ascensão da saúde pública como campo profissional da educação física e que merece formação específica desde que pautada em princípio de acordo com as reformas sanitárias e com a perspectiva da promoção da saúde. O diálogo com a Saúde Coletiva pode fornecer tais diretrizes que, ao longo dos próximos anos, deveria ser pautada na agenda das discussões curriculares da formação em educação física.

- Ao defender a inserção da educação física na saúde pública, em especial na saúde mental, é preciso ser crítico ante as necessárias mudanças do ponto de vista da configuração do trabalho multidisciplinar em que se operam os CAPS. A subjetividade social hierarquizada entre diversas áreas de conhecimento parece contradizer a busca por uma perspectiva de trabalho interdisciplinar. Ademais, isto acaba recrudescendo a lógica medicalocêntrica e hospitalocêntrica tão difundida na sociedade brasileira no que diz respeito às políticas de saúde. Tal fato contradiz a possibilidade de assistência em saúde com base na promoção da saúde e na produção de um modo de vida saudável, e na qual registramos aqui nosso agravo. Nesse sentido, em se tratando de saúde mental, o ponto de convergência das áreas, em nossa opinião, deve ser aquele que preserve a compreensão de uma ciência complexa e que intervenha profissionalmente, enaltecendo o desenvolvimento dos processos de subjetivação das práticas laborais. 
- A teoria da subjetividade numa perspectiva cultural-histórica nos oferece a possibilidade de ressignificar as práticas corporais na educação física. Abre assim uma zona de sentido antes não explorada na área. $O$ presente estudo inicia o desenvolvimento teórico de se pensar as práticas corporais como produção de sentidos subjetivos. Dessa forma, procura-se enaltecer e valorizar o sujeito da prática em detrimento da prática puramente corporal. Defendemos que em se tratando de saúde, esta sempre deve se submeter ao sujeito e não o contrário. Não se trata do sujeito que serve e se subordina a uma determinada prática corporal, mas sim da prática corporal que serve e se subordina ao sujeito. Nesse sentido, quem atribui valor social a uma determinada prática corporal é o sujeito da prática. Defendemos isso como forma de não alienar ou assujeitar o sujeito que se propõe a viver as práticas corporais e, ao mesmo tempo, não incidir sobre as práticas corporais uma tipologia axiológica que acaba conduzindo a estereotipar e dar um caráter meramente funcional às práticas corporais. Por exemplo, no âmbito das atividades físicas e no contexto de uma saúde midiatizada, há uma tradição em valorizar as práticas "que queimam mais calorias". Estas se inscrevem como "melhores" do que outras, pois o objetivo é combater a obesidade. Não se trata aqui de criticar a redução da saúde a um determinado problema específico (a obesidade), uma vez que tal problema é de fato importante e é alvo das preocupações da saúde pública. Entretanto, desde nossa perspectiva teórica, o combate à obesidade não se dá "fora do sujeito", ou seja, não basta se externalizar o problema e prescrever a ele aquela prática de maior queima de calorias. Para nós, antes disso (não se trata de proibir qualquer prática corporal) é necessário valorizar e trabalhar em prol da emergência da subjetividade do indivíduo na escolha de uma prática e que este se implique emocionalmente a esta prática corporal a fim de que isso possa resultar num auxilio ao combate a sua obesidade. Esse exemplo, num contexto diferente daquele sobejamente discutido ao longo da tese na saúde mental, demonstra para nós o potencial da teoria da subjetividade de González Rey e tal entendimento sobre as práticas corporais como produção de 
sentidos subjetivos no que se refere a outras práticas sociais da educação física.

Embora sejamos enfáticos em nossas colocações, vale relativizar nossas elaborações em função de nos situarmos num campo relativamente novo na educação física, qual seja o da saúde pública e da saúde mental. Além disso, procurando ser pioneiros em uma aproximação teórico-epistemológica à Teoria da Subjetividade na área da educação física. De todo modo, ter colocado em perspectiva tal aproximação nos pareceu um avanço minimamente significativo. Como vimos, há um corpo teórico-conceitual presente e consolidado na Teoria da Subjetividade de González Rey. Outro fator não menos importante é o de perceber que este autor permanece extremamente produtivo atualmente, dando respostas aos seus próprios ensinamentos de que a ciência não é um bloco monolítico e inescrutável. A abertura de sua teoria, transcendendo os limites da psicologia é, talvez, o maior exemplo de que a compreensão da subjetividade numa perspectiva cultural-histórica reside em aceitar a complexidade do mundo. Com efeito, a ciência afeita às elaborações teóricas do ser humano, possui sempre caráter processual. Quando percebemos a trajetória "recente" da educação física no debate científico, as ideias de González Rey nos alimentam de pensarmos uma prospectiva otimista diante do enriquecimento epistemológico da área a partir da subjetividade.

Estamos certos de que a educação física ao pensar o corpo como seu objeto de conhecimento deve integrá-lo a uma abordagem sistêmica e complexa. Até aqui a área deu saltos significativos em compreender o corpo para além de sua perspectiva biológica e, também, vem cada vez mais amadurecendo sua compreensão segundo uma dimensão social, histórica e cultural. Talvez fosse o momento de assimilar os estudos da subjetividade como forma de romper com a cara influência imposta pelo positivismo e pelo estruturalismo sociológico, reivindicando um fazer científico ciente da necessidade da emergência dos sujeitos implicados nas pesquisas - aspecto que a educação física em seus estudos tem escanteado. Portanto, entendemos que a assunção da subjetividade nos processos de investigação científica é uma condição sine qua non para a 
compreensão da complexidade humana. Parafraseando Edgar Morin: precisamos cada vez mais nos preocupar em ocultar cada vez menos a complexidade do real. 


\section{VI - Referências}

ABIB, L. T. et. al. Práticas corporais em cena saúde mental: potencialidades de uma oficina de futebol em um Centro de Atenção Psicossocial de Porto Alegre. In.: Pensar a Prática, Goiânia, v. 13, n. 2, p.1-15, maio/agosto, 2010.

AMARANTE, P. Asilos, alienados e alienistas: uma pequena História da Psiquiatria no Brasil. In: AMARANTE, P. (Org.). Psiquiatria social e reforma psiquiátrica. Rio de Janeiro: Fiocruz, 1994.

Loucos pela vida: a trajetória da reforma psiquiátrica no Brasil. Rio de Janeiro: Editora Fiocruz, 1995.

. O homem e a serpente: outras histórias para a loucura e a psiquiatria. Rio de Janeiro: Editora Fiocruz, 1996.

ARBEX, D. Holocausto Brasileiro. São Paulo: Geração, 2013.

BAGRICHEVSKY, M. A formação profissional em educação física enseja perspectivas (críticas) para a atuação na saúde coletiva? In: FRAGA, A. B., WACHS, F (Orgs.). Educação física e saúde coletiva: políticas de formação e perspectivas de formação. Porto Alegre: Editora da UFRGS, 2007.

BAGRICHEVSKY, M. ESTEVÃO, A. Os sentidos da saúde e a educação física: apontamentos preliminares. In: Revista Arquivos em Movimento. Rio de Janeiro: v.1, n.1, p.65-74, janeiro/junho, 2005.

BARROS, D.D. Cidadania versus periculosidade social: a desinstitucionalização como desconstrução do saber. In: Paulo Amarante (Org.). Psiquiatria Social e Reforma Psiquiátrica. Rio de Janeiro: Editora FIOCRUZ, 1994.

BERGER, P. L.; LUCKMANN, T. A construção social da realidade. Petrópolis, RJ: Vozes, 2011.

BRACHT, V. Educação física e ciência: cenas de um casamento (in)feliz. ljuí, RS: Unijuí, 2007.

; ALMEIDA, F. Q. Emancipação e diferença na educação: uma leitura com Bauman. Campinas: Autores Associados, 2006.

BRASIL, LEIS, etc. Lei 10.216, de 06 de abril de 2001. "Dispõe sobre a proteção e os direitos das pessoas portadoras de transtornos mentais e redireciona o modelo assistencial”. In: BRASIL. MINISTÉRIO DA SAÚDE. Legislação em saúde mental. 1990-2004. Série E. Legislação de Saúde. 5. ed. ampliada. Brasília, 
2004.

BIRMAN, J; COSTA, J. F. Organização de instituições para uma psiquiatria comunitária. In: AMARANTE, P. (Org.). Psiquiatria Social e Reforma

Psiquiátrica. Rio de Janeiro: Editora Fiocruz, 1994.

BRASIL. Saúde Mental no SUS: os centros de atenção psicossocial. Brasília: Ministério da Saúde, 2004.

Saúde Mental em dados 10. Brasília: Ministério da Saúde. Secretária de Atenção à Saúde, 2012.

BUSS, P. M. Promoção da saúde e qualidade de vida. Ciência e Saúde Coletiva. Rio de Janeiro, v.5, n.1, p.163-177, 2000.

CAMPOS, G. W. S. A saúde pública e a defesa da vida. São Paulo: Hucitec, 1991.

CANGUILHEM, G. O normal e o patológico. Rio de Janeiro: Editora Forense Universitária, 1982.

CARVALHO, Y. M. Atividade física e saúde: onde está e quem é o "sujeito" da relação? In: Revista Brasileira de Ciências do Esporte, Campinas, v. 22, nº 2 , 9-21, jan. 2001.

. 0 "mito" da atividade física e saúde. São Paulo: Hucitec, 2004.

. Entre o biológico e o social: tensões no debate teórico acerca da saúde na educação física. In: Motrivivência, Florianópolis, ano XVII, n. 24, p.97-105, jun/2005.

Saúde, sociedade e vida: um olhar da educação física. In: Revista Brasileira de Ciências do Esporte, Campinas, v. 27, nº 3, 153-168, maio, 2006.

CASTEL, R. A ordem psiquiátrica: a idade de ouro do alienismo. Rio de Janeiro: Graal, 1978.

CECCIM, R. B.; BILIBIO, L. F. Singularidades da educação física na saúde: desafios à educação de seus profissionais e ao matriciamento interprofissional? In: FRAGA, A. B., WACHS, F (Orgs.). Educação física e saúde coletiva: políticas de formação e perspectivas de formação. Porto Alegre: Editora da UFRGS, 2007.

CONCEIÇÃO, M. R. et. al. Interferências criativas na relação ensino-serviço: itinerários de um Programa de Educação pelo Trabalho para a Saúde. Interface. Botucatu, v.19, suplemento I, p.845-855. 
COSTA, J. F. Ordem médica e norma familiar. Rio de Janeiro: Edições Graal, 1983.

COSTA J. M., KIPNIS, B. O debate epistemológico na formação do pesquisador da educação: reflexões a partir de alguns epistemólogos modernos. Educação em Perspectiva. Viçosa (MG), v.5, n.1, p.9-29, jan./jun. 2014.

. GOULART, D. M. A saúde humana como produção subjetiva:

aproximando clínica e cultura. Psicologia e Sociedade, v.27, n.1, p.240-242, 2015.

CZERESNIA, D. Categoria vida: reflexões para uma nova biologia. São Paulo: Editora UNESP. Rio de Janeiro: Editora Fiocruz, 2012.

DAOLIO, J. Educação Física Brasileira: autores e atores da década de 1980. Campinas: Papirus, 1998.

DAMICO, J. G. S.; Knuth, A. G. O des(encontro) das práticas corporais e atividade física: hibridizações e borramentos no campo da saúde. In: Movimento, PortoAlegre, v.20, n. 1, p.329-350, jan/mar de 2014.

DANZINGER, K. Constructing the subject: historical origins of psychological research. New York: Cambridge University Press, 1990.

FENSTERSEIFER, Paulo. A Educação física na crise da modernidade. ljuí, RS: Unijuí, 2001.

FEYERABEND, P. K. Contra o método. São Paulo: Editora UNESP, 2011.

FLEURY, S. (Org.). Saúde: Coletiva? Questionando a onipotência do social. Rio de Janeiro: Relume-Dumará, 1992.

FOUCAULT, M. Microfísica do poder. Rio de Janeiro: Edições Graal, 1979. . O nascimento da clínica. Rio de Janeiro: Forense Universitária, 2008.

FRAGA, A. B. Anatomias emergentes e o bug muscular: pedagogias do corpo no limiar do século XXI. In: C. L. SOARES. (Org.). Corpo e história. Campinas: Autores Associados, 2001.

, CARVALHO, Y.M., GOMES, I. (Orgs). As práticas corporais no campo da saúde. São Paulo: Hucitec, 2013.

GERGEN, K. J. O movimento do construcionismo social na psicologia moderna. Florianópolis, Revista Intertheses, v.6, n.1, p.299-325, jan/jul, 2009. 
GOFFMAN, E. Manicômios, prisões e conventos. São Paulo: Perspectiva, 1974.

GONÇALVES, A. Saúde e América Latina: contribuições conceituais e metodológicas. In: Revista Brasileira de Ciências do Esporte, Campinas, v. 12, $n^{\circ} 1,59-72,1989$.

GONZÁLEZ REY, F. Epistemología cualitativa y subjetividad. Havana: Pueblo y Educación, 1997.

Personalidade, saúde e modo de vida. São Paulo: Pioneira Thomson Learning, 2004.

. Sujeito e subjetividade: uma aproximação histórico-cultural. São Paulo: Pioneira Thomson Learning, 2005a.

. Pesquisa qualitativa em psicologia: caminhos e desafios. São Paulo: Pioneira Thomson Learning, 2005b.

O valor heurístico da subjetividade na investigação pedagógica. In: GONZÁLEZ REY. F. (Org.) Subjetividade, complexidade e pesquisa em psicologia. São Paulo: Pioneira Thomson Learning, 2005c.

. Pesquisa qualitativa e subjetividade: os processos de construção da informação. São Paulo: Pioneira Thomson Learning, 2005d.

. O sujeito que aprende: desafios do desenvolvimento do tema da aprendizagem na psicologia e na prática pedagógica. In.: TACCA, M. C. V. R. (Org). Aprendizagem e trabalho pedagógico. Campinas: Editora Alínea, 2006.

Psicoterapia, subjetividade e pós-modernidade: uma aproximação histórico-cultural. São Paulo: Pioneira Thomson Learning, 2007.

Cortez, 2011a.

Subjetividade e Saúde: superando a clínica da patologia. São Paulo:

. Sentidos subjetivos, lenguaje y sujeto: analizando una perspectiva post racionalista en psicoterapia. Rivista di Psichiatria, v. 46, p. 310-314, 2011 b.

O social na psicologia e a psicologia no social: a emergência do sujeito. Petrópolis, RJ: Vozes, 2012a.

O pensamento de Vigotsky: contradições, desdobramentos e desenvolvimento. São Paulo: Hucitec, 2012b. 
. A saúde na trama complexa da cultura, das instituições e da subjetividade. In.: GONZÁLEZ REY, F., BEZERRIL, J. (Orgs.). Saúde, cultura e subjetividade: uma referência interdisciplinar. Brasília: UniCEUB, 2015.

GOULART, D. M. Autonomia, saúde mental e subjetividade no contexto assistencial brasileiro. Revista Científica Guillermo de Ockham. Calí, Colômbia, v.11, n.1, p.21-33, jun. 2013a.

. Institucionalização, subjetividade e desenvolvimento humano:

abrindo caminhos entre educação e saúde mental. 145f. Dissertação (Mestrado em Educação) - Programa de Pós-graduação em Educação, Faculdade de Educação, UnB, Brasília, 2013b.

. Clínica, subjetividade e educação: uma integração teórica alternativa para forjar uma ética do sujeito no campo da saúde mental. In.: GONZÁLEZ REY, F., BEZERRIL, J. (Orgs.). Saúde, cultura e subjetividade: uma referência interdisciplinar. Brasília: UniCEUB, 2015.

GUIMARÃES, A. C., PASCOAL, R. C., CARVALHO, I. Z., ADÃO, K. S. A inserção social através de práticas de educação física como medidas interventivas para pacientes psicóticos e neuróticos graves do CAPS de São João del-Rei/MG. Pesquisas e Práticas Psicossociais. São João del-Rei, v.7, n.2, p.254-259, jul./dez. 2012.

FURTADO, R. P. O trabalho do professor de educação física no CAPS: aproximações iniciais. Movimento. Porto Alegre, v.21, n.1, p.41-52, jan./mar. 2015.

HEIDMANN, I.T et. al. Promoção à saúde: trajetória histórica de suas concepções. Texto \& Contexto. Florianópolis, v.15, n.2, p.352-358, 2006.

KEMPER, M. L. C et. al. Integralidade e redes de cuidado: uma experiência do PET-Saúde/Rede de Atenção Psicossocial. Interface. Botucatu, v.19, suplemento I, p.995-1003.

JONES, M. A comunidade terapêutica. Petrópolis: Vozes, 1972.

LíRIO, A. P. S. Práticas corporais na saúde mental: um relato de experiência do CAPS AD "Primavera" Aracajú/SE. Congresso Brasileiro de Ciências do Esporte. Anais. Porto Alegre, 2011.

LOBOSQUE, A. M. Clínica em movimento: por uma sociedade sem manicômios. Rio de Janeiro: Garamond, 2003. 
LOUGON, M. Desinstitucionalização da assistência psiquiátrica: uma perspectiva crítica. Physis - Revista de Saúde Coletiva, v.3, n.2, p.137-164, 1993.

MITJÁNS MARTÍNEZ, A. A teoria da subjetividade de González Rey: uma expressão do paradigma da complexidade na psicologia. In: GONZÁLEZ REY. F. (Org.) Subjetividade, complexidade e pesquisa em psicologia. São Paulo: Pioneira Thomson Learning, 2005.

. Criatividade no trabalho pedagógico e criatividade na aprendizagem: uma relação necessária. In.: TACCA, M. C. V. R. (Org.). Aprendizagem e trabalho pedagógico. Campinas: Editora Alínea, 2006.

. Aprendizagem criativa: uma aprendizagem diferente. In.: MITJÁNS MARTÍNEZ, A., SCOZ, B. J. L., CASTANHO, M. I. S. (Orgs.). Ensino e aprendizagem: a subjetividade em foco. Brasília: Liber Livros, 2012.

MORIN, E. Introdução ao pensamento complexo. Porto Alegre: Sulina, 2006 PAIM, J. O que é o SUS? Rio de Janeiro: Editora Fiocruz, 2009.

PALMA, A. Atividade física, processo saúde-doença e condições sócioeconômicas: uma revisão da literatura. In.: Revista Paulista de Educação Física, São Paulo, v.14, n.1, p.97-106, jan/jun 2000.

. Educação Física, corpo e saúde: uma reflexão sobre outros "modos de olhar". In: Revista Brasileira de Ciências do Esporte, Campinas, v. 22, n 2, 2339, jan. 2001.

; SALOMÃO, L.C.; NICOLODI, A. G.; CALDAS, A. Reflexões acerca da adesão aos exercícios físicos: comportamento de risco ou vulnerabilidades? In.: Revista Movimento, v.10, n.21, p.83-100, 2003.

PIGNARRE, P. O que é o medicamento?: um objeto estranho entre ciência, mercado e sociedade. São Paulo: Editora 34, 1999.

QUINT, F. O. et. al. Reflexões sobre a inserção da educação física no programa saúde da família. In: Motrivivência, Florianópolis, ano XVII, n. 24, p.97-105, jun/2005.

REGNER, A. C. K. P., Feyerabend e o pluralismo metodológico. Epistéme: Filosofia e História da Ciência em Revista. Porto Alegre, vol.1, No. 2, 1996.

ROBLE, O. J., MOREIRA, M. I. B., SCAGLIUSI, F. B. A educação física na saúde mental: construindo uma formação na perspectiva interdisciplinar. Interface. Botucatu, v.16. n.41, p.567-577, abr.jun. 2012. 
ROSA, R. P. F et. al. Construindo saberes no trabalho em saúde mental: experiências de formação em saúde. Interface. Botucatu, v.19, suplemento I, p.931-940.

ROSE, N. Inventando nossos selfs. Rio de Janeiro: Editora Vozes, 2011.

ROTELLI, F. Superando o manicômio - o circuito psiquiátrico de Trieste. In: AMARANTE, P. (Org.). Psiquiatria social e reforma psiquiátrica. Rio de Janeiro: Fiocruz, 1994.

SILVA, J. R. A. et. al. Atividade física e saúde mental: uma experiência na formação inicial em educação física. Revista Brasileira de Atividade Física e Saúde. Pelotas, n.19, v.1, p.133-140, jan. 2014.

SILVA, P. F. A., BAPTISTA T.V.F. Os sentidos e disputas na construção da Política Nacional de Promoção da Saúde. Physis - Revista de Saúde Coletiva. Rio de Janeiro, v.24, n.2, p.441-465, 2014.

SOLON, L. R. Homeopatia e subjetividade. In.: GONZÁLEZ REY. F. (Org.) Subjetividade, complexidade e pesquisa em psicologia. São Paulo: Pioneira Thomson Learning, 2005.

SCOZ, B. J. L. A subjetividade na psicopedagogia: algumas reflexões. Construção Psicopedagógica. São Paulo, v.17, n.14, 60-74, jun/2009.

. TACCA, M. C. V. R., CASTANHO, M. I. S. Subjetividade, ensino e aprendiz agem: contribuições de pesquisas acadêmicas. In.: MITJÁNS MARTÍNEZ, A., SCOZ, B. J. L., CASTANHO, M. I. S. (Orgs.). Ensino e aprendizagem: a subjetividade em foco. Brasília: Liber Livros, 2012.

SOARES, C. L. Educação Física: raízes europeias e Brasil. Campinas: Autores Associados, 2007.

SUS/CNS. Relatório Final da IV Conferência Nacional de Saúde Mental. Brasília: Conselho Nacional de Saúde / Ministério da Saúde, 2010.

TELES, A. M. O. CERQUEIRA, T. C. S. A pedagogia do si-mesmo: debate sobre a emergência do sujeito que aprende. Porto Alegre, Educação \& Realidade, v.38, n.3, p.931-951, jul/set, 2013.

TENÓRIO, F. A reforma psiquiátrica brasileira, da década de 1980 aos dias atuais: história e conceitos. História, Ciências, Saúde Manguinhos. Rio de Janeiro, v. 9, n.1, p.25-59, 2002.

VEIT, A., ROSA, L. R. Educação física e intervenção na saúde mental. Cadernos Pedagógicos. Lageado/RS, v.12, n.1, p.301-311, 2015. 
WACHS, F., FRAGA, A. B. Educação física em centros de atenção psicossocial. In: Revista Brasileira de Ciências do Esporte, Campinas, v. 31, n 1, p.93-107, set. 2009. 